
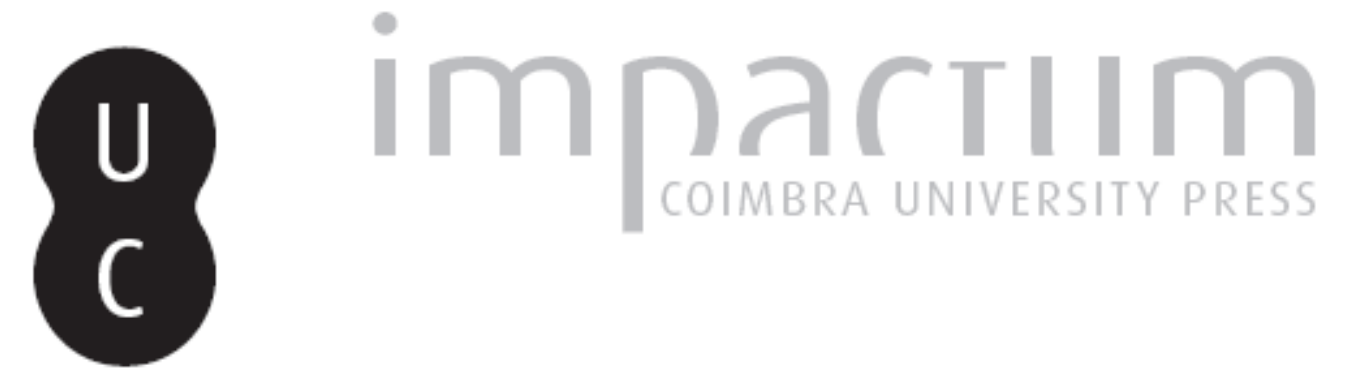

\title{
Bibliografia de António Sérgio
}

\section{Autor(es): $\quad$ Matos, A. Campos}

Publicado por: Imprensa da Universidade de Coimbra

URL persistente:

URl:http://hdl.handle.net/10316.2/45063

DOI:

DOI:https://doi.org/10.14195/2183-8925_5-2_7

Accessed : $\quad$ 26-Apr-2023 09:13:56

A navegação consulta e descarregamento dos títulos inseridos nas Bibliotecas Digitais UC Digitalis, UC Pombalina e UC Impactum, pressupõem a aceitação plena e sem reservas dos Termos e Condições de Uso destas Bibliotecas Digitais, disponíveis em https://digitalis.uc.pt/pt-pt/termos.

Conforme exposto nos referidos Termos e Condições de Uso, o descarregamento de títulos de acesso restrito requer uma licença válida de autorização devendo o utilizador aceder ao(s) documento(s) a partir de um endereço de IP da instituição detentora da supramencionada licença.

Ao utilizador é apenas permitido o descarregamento para uso pessoal, pelo que o emprego do(s) título(s) descarregado(s) para outro fim, designadamente comercial, carece de autorização do respetivo autor ou editor da obra.

Na medida em que todas as obras da UC Digitalis se encontram protegidas pelo Código do Direito de Autor e Direitos Conexos e demais legislação aplicável, toda a cópia, parcial ou total, deste documento, nos casos em que é legalmente admitida, deverá conter ou fazer-se acompanhar por este aviso.

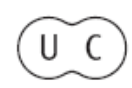




\section{REVISTA DE HISTÓRIA DAS IDEIAS 5}

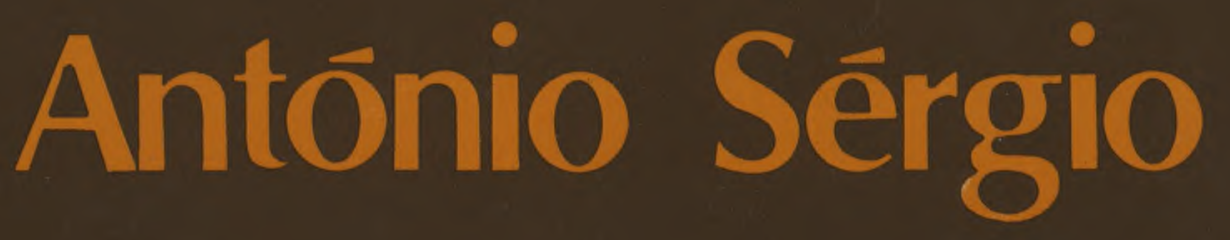

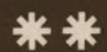

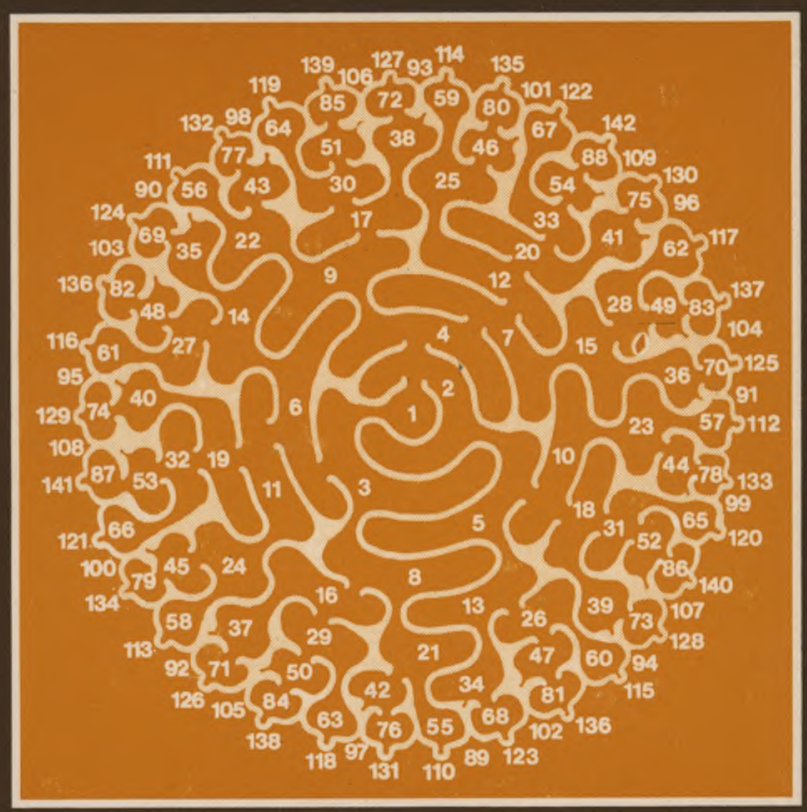

INSTITUTO DE HISTÓRIA E TEORIA DAS IDEIAS FACULDADE DE LETRAS

COIMBRA 1983 


\section{A. CAMPOS MATOS*}

\section{BIBLIOGRAFIA DE ANTÓNIO SÉRGIO}

Bibliografia de António Sérgio, eis o título com que uma primeira versão deste trabalho foi publicada no n. ${ }^{\circ} 319-320$ da revista Vértice, em 1971 e, de seguida, já melhorada, em separata do mesmo ano.

A ideia da presente reedição desse material resultou do convite que nos dirigiu o dr. Fernando Catroga, ao entender que constituiria obra de préstimo para figurar no número da Revista da História das Ideias, da Faculdade de Letras de Coimbra, comemorativo do centenário do nascimento do autor dos Ensaios.

Desde logo nos ocorreu não só actualizar, rever e refundir a versão da Vértice, que contava já uma década, mas de a completar com elementos respeitantes à bibliografia passiva do ensaísta, ou seja, essencialmente, os estudos publicados sobre a sua obra, matéria esta que poderá vir a constituir, também, útil instrumento de investigação e de consulta.

Quanto à bibliografia activa, o que agora aqui surge de novo, além de alguns volumes das obras completas publicados pela Sá da Costa, de uns tantos textos de carácter político e de muita colaboração em jornais diários, é, eminentemente, a correspondência do escritor, capítulo imenso, com foros de infindável. Repare-se que numa missiva a João de Barros, recentemente publicada $\left({ }^{x}\right)$, Sérgio confessa que naquela tarde já havia escrito 16 cartas!

Desta imensa actividade epistolar, que vai surgindo dia a dia em livros e publicações periódicas, ressaltam dois as-

\footnotetext{
* Ensaísta

(') Cartas Políticas a João ãe Barros. Lisboa, Imprensa Nacional, 1982, p. 298.
} 
pectos essenciais da vida de António Sérgio: a sempre vivíssima e indefectível actividade do resistente político ao fascismo salazarista, a cuja queda não chegou a assistir, e o irrequieto labor intelectual deste fulgurante maître à penser no convívio com os melhores espíritos do seu tempo e na faina de expor, clarificar e esclarecer o seu ideário de reformador social.

Não foi possível, ainda desta vez, proceder à prospecção total da colaboração de Sérgio em jornais como o Diário Liberal, Diário da Noite, República, Diário de Lisboa, Diário Popular e Primeiro de Janeiro, para só mencionar os principais. Recolhemos, no entanto, um acervo importante da sua colaboração em alguns desses periódicos, em áreas fundamentais do seu pensamento cooperativista e político (períodos eleitorais do salazarismo).

Como novidade, que supomos desconhecida para grande parte dos sergianistas: conseguimos referenciar a publicação Le Portugal, desenvolvido bosquejo de 156 páginas publicado em 1933 para uma reunião internacional da Association des Anatomistes, realizada nesse ano em Lisboa. Sérgio enviara em Novembro de 1932, do seu exílio de Paris, ao prof. Celestino da Costa, cinco capítulos de um trabalho constituído por «geografia, história, literatura, artes, colónias». Possuía o prof. Jaime Celestino da Costa, seu filho, um exemplar da publicação a que tal trabalho se destinava, confirmando a sua origem. E uma obra abundantemente ilustrada, tendo na capa uma excelente vista do palácio velho de Sintra, mas sem qualquer referência de autor, editor e data. Ajudou ainda a esclarecer este caso o prof. Xavier Morato, que fora assistente do prof. Celestino da Costa, ao relatar-nos as circunstâncias que envolveram a publicação. Doía a Celestino da Costa, de há muito, o desconhecimento com que na Europa se referia Portugal, nos congressos internacionais que frequentava. Isto levara-o a aproveitar a oportunidade de uma reunião internacional de anatomistas em Lisboa, para lançar, em língua francesa, esse amplo bosquejo sobre o seu país. Quem melhor do que o seu amigo Sérgio, então exilado em Paris, e já autor em 1923 e 1929 de dois trabalhos do género, o Bosquejo da História de Portugal e a História de Portugal (ed. Labor), para elaborar o corpo principal do texto? Por outro lado, tratava-se também de uma oportunidade de ajudar economicamente o ensaísta. E assim se publicou esse trabalho, anonimamente, por motivos políticos.

Esclarecemos ainda que somos levados a considerar esta versão da bibliografia de António Sérgio, mau grado o curtíssimo prazo que tivemos para a desenvolver e o facto de se 
tratar de um trabalho empreendido nas horas livres, como mais um passo, necessariamente não completo, que só futuras reedições poderão aperfeiçoar.

Concluiremos com uma palavra de agradecimento para a prestantíssima e constante ajuda que nos proporcionou o dr. Jacinto Baptista, fraterno e sergiano Amigo, a quem se deve a publicação e o estudo da correspondência de Sérgio com Sarmento Pimentel e com Bernardino Machado, ele próprio tão interessado como nós na qualidade deste trabalho. Também os nomes do Arq.to Cabeça Padrão e de Castelo Branco Chaves, que figuraram na sua primeira versão, não poderiam deixar de aqui voltar, pela utilíssima prestação das suas informações.

Devemos mencionar, finalmente, a colaboração excelente do dr. António Ribeiro de Almeida quanto à recolha efectuada, nomeadamente em jornais diários. 


\section{I - BIBLIOGRAFIA ACTIVA}

a - Livros, opúsculos e separatas

b - Colaboração em publicações periódicas

c - Prefácios, notas e organização de edições *

d - Colaboração em obras colectivas

e - Epistolário: e 1 - em livros

e 2 - em publicações periódicas

$\mathrm{f}$ - Entrevistas e inquéritos $\mathrm{f} 1$ - em livros

f 2 - em publicações periódicas

g-Traduções

f 3 - em disco

h - Representação em antologias

\section{II - BIBLIOGRAFIA PASSIVA}

a - Estudos exclusivos sobre a obra

b - Publicações com estudos ou referências sobre a obra

c - Artigos, em publicações periódicas, com estudos ou referências sobre a obra.

$$
\text { cl - não assinados }
$$

d - Publicações especiais de homenagem ou comemoração

e - Representação em dicionários e enciclopédias

f-Sobre as polémicas: f 1 - artigos não assinados

f 2 - artigos assinados

g - Artigos sobre a casa de António Sérgio e sua biblioteca:

h - Necrologia

g 1 - não assinados

g 2 - assinados

i - Bibliografias

j-Elementos biográficos

III _ RESENHA DAS PUBLICAÇÕES PERIÓDICAS CITADAS NESTA BIBLIOGRAFIA

\footnotetext{
* Ver também prefácios e notas relativos às traduções.
} 


\section{Ia LIVROS, OPÚSCULOS E SEPARATAS}

Rimas. Lisboa, Tip. do Anuário Comercial, 1908, 160 p.

Notas sobre os sonetos $e$ as tendências geraes da philosophia de Antero de Quental. Lisboa, Livraria Ferreira Editora, 1909, 189 p.

Da natureza da affecção. Ensaios de psycologia e pedagogia. (Separata do.$^{\circ}$ 9, ano IV da Revista Americana). Rio de Janeiro, 1913, 39 p.

O problema da cultura e o isolamento dos povos peninsulares. Porto, Renascença Portuguesa, 1914, 67 p.

O navio dos brinquedos, s. 1. (Porto), Biblioteca Renascença Portuguesa, 1914. Ilust., 15 p.

Educação cívica. Porto, Renascença Portuguesa, 1915, 145 p. 2.a ed., Lisboa, Editorial Inquérito, L.da, 1954, 85 p.

Um programa, s. e., s. d., s. 1. (Lisboa), (1915?), 4 p.

Considerações histórico-pedagógicas. Antepostas a um Manual de instrução agrícola na escola primária (Separata). Porto, Renascença Portuguesa, 1916. 2. ${ }^{a}$ ed. Porto, Renascença Portuguesa, $61 \mathrm{p}$.

Educação geral e actividade particular. Duas cartas a Cardoso Gonçalves sobre a distinção entre ensino primário e profissional. (Opúsculo), 1916.

Cartas sobre a educação profissional escritas ao director da Academia de Estudos Livres. Educação profissional na Casa das Crianças e na Escola Primária. Porto, Renascença Portuguesa, 1916, 39 p.

Questões pedagógicas. Carta ao director da Academia de Estudos Livres Dr. Cardoso Gonçalves e segunda carta. Lisboa, Anais da Academia de Estudos Livres, Universidade Popular. N. ${ }^{\circ}$ 2, 1915$-1916,175-190 \mathrm{pp}$.

A função social dos estudantes e a sua preparação para a intervenção futura na Sociedade Portuguesa. Porto, Renascença Portuguesa, 1917, 44 p.

Noções de zoologia (Mamíferos). Compendiadas e coordenadas. Porto, Renascença Portuguesa, 1917, 103 p.

Comentários. (Aspectos morais. Os católicos portugueses. História para o Povo. A Polémica Ricardo-Teófilo a propósito da biografia de Rodrigues Lobo. Parte do $1 .^{\circ}$ capítulo foi suprimida pela censura). Lisboa, Oficinas do Anuário Comercial, 1917, 30 p. 
$O$ ensino como factor do ressurgimento nacional. Defeito dos nossos métodos de ensino e maneira de os corrigir; linhas gerais de uma nova organização. Porto, Renascença Portuguesa, 1918, 53 p.

Ensaios I, c/ prefácio e os ensaios seguintes: ciência e educação; educação e filosofia; espectros; a educação cívica, a liberdade e o patriotismo antigos e modernos; da opinião pública e da competência em democracia; interpretação não romântica do sebastianismo; a conquista de Ceuta; o caprichismo romântico na obra do snr. Junqueiro. Rio de Janeiro, Anuário do Brasil, 1920, 444 p. 2..$^{a}$ ed. Coimbra, Atlântida, 1949 (c/ novo prefácio), 461 p. l. ${ }^{a}$ ed. das Obras Completas, Lisboa, Livr. Sá da Costa, 1971, 412 p.

O problema pedagógico, in União Cívica, Conferências de Propaganda. Lisboa, Sociedade de Geografia. Ed. da Comissão Directiva do Norte, 1923, 29-34 pp.

Bosquejo da História de Portugal. Lisboa, Publicações da Biblioteca Nacional, 1923. 2. ${ }^{\mathrm{a}}$ ed., $60 \mathrm{p}$.

Virtudes fundamentais da reforma da educação. Lisboa, s. e. (Sociedade de Geografia de Lisboa?), 1923, 31 p.

Um crime, Lisboa, Oficinas gráficas da Biblioteca Nacional, 16 de Nov. de 1923, 4 p. (c/ colab.)

Oliveira Martins. Impressões sobre o significado político da sua obra. Lisboa, Oficina Gráfica da Biblioteca Nacional, 1923, 88 p. (Separata do prefácio aos Dispersos de Oliveira Martins)

O Desejado. Depoimentos de contemporâneos de $D$. Sebastião sobre este mesmo rei e sua jornada de África, precedidos de uma carta-prefácio a Carlos Malheiro Dias. Lisboa, Livrarias Aillaud e Bertrand, 1924. 2a ed., Lisboa, Livrarias Aillaud e Bertrand, 1924, 374 p.

Introdução historica. In Guia de Portugal, $10^{\circ}$ volume, generalidades, Lisboa e arredores. Lisboa, Biblioteca Nacional, 1924, 672 p.

Na terra $e$ no mar (cinco contos infantis; a guerra do grilo e do leão; a esperteza da rapoza; história da baleia; o príncipe encantado; história do José Maria). Lisboa, Livrarias Aillaud e Bertrand, 1924. Ilust., 61 p. $2^{a}$ ed. Col. Obras Infantis de António Sérgio, vol. III, Lisboa, Livr. Sá da Costa, 1978, 59 p.

Sobre a política de Camões. In $4 .^{\circ}$ Centenário do Nascimento de Camões, 1524-1924, 24-27 pp. Lisboa, 1924.

Tréplica a Carlos Malheiro Dias sobre a questão de O Desejado. Lisboa, Seara Nova, 1925, $94 \mathrm{p}$.

Camões $e$ D. Sebastião. Rudimentar organização de documentos para o estudo de um problema curioso. Lisboa, Livrarias Aillaud e Bertrand, 1925, 54 p.

Contos gregos. (Três contos infantis: Filémon e Báucis; História dos Argonautas; o cão de Ulisses). Paris-Lisboa, Livrarias Aillaud e Bertrand, 1925. 2a ed., Paris-Lisboa, Livrarias Aillaud e Bertrand, 1925. Ilust., 46 p. $2^{\text {a }}$ ed., Col. Obras Infantis de António Sérgio, vol. IV, Lisboa, Livr. Sá da Costa, 1978, 59 p.

O seiscentismo. Reprodução do artigo em que, segundo dizem os que me odeiam, insultei um morto e falsiquei textos, s. 1. (Lisboa), Seara Nova, 1926, 48 p.

A dança dos meses. (Três contos infantis: a dança dos meses; as duas bonecas; o menino que teimou). Lisboa, Seara Nova, 1926. Ilust., 30 p. 2 a ed., Col. Obras Infantis de António Sérgio, vol. II, Lisboa, Livr. Sá da Costa, 1978, 45 p. (Vol. intitulado: Os Conselheiros do Califa) 
$O$ ratão pelado. (Dois contos infantis: o ratão pelado e a cabana dos lobos). Lisboa, Seara Nova, 1926. Ilust., 32 p. 2. ${ }^{a}$ ed., Col. Obras Infantis de António Sérgio, vol. I, Lisboa, Livr. Sá da Costa, 1978, 56 p. (Vol. intitulado: Os Dez Anóezinhos da Tia Verde Agua)

Os Conselheiros do Califa. (Dois contos infantis: os conselheiros do califa; o cavalo de Alexandre). Lisboa Livrarias Aillaud e Bertrand, 1927. Ilust., 24 p. $2 .^{\circ}$ ed., Col. Obras Infantis de António Sérgio, vol. II, Lisboa, Livr. Sá da Costa, 1978, 47 p. (contém os contos: O cavalo de Alexandre, A dança dos meses, As duas bonecas e o Menino que Teimou em não querer comer a sopa)

Carta aberta a alguns dos oficiais republicanos que não estiveram com a Revolução. (Lisboa). Ed. da «Liga Republicana», s. d. (1927?), 12 p.

Carta aberta aos oficiais portugueses que admitem a ditadura 136-148 pp. Para a preparação do após-ditadura 148-157 pp. Acta $n .^{\circ}$ 9, 25-26 pp. (dois textos-proposta), in: A Liga de Paris $e$ a Ditadura Militar 1927-1928, História de Portugal Contemporâneo. Documentos, vol. IV, direc. de A. H. de Oliveira Marques, Lisboa, Publ. Europa-América, 1976, 298 p.

A sketch of the History of Portugal. Lisboa, Seara Nova, 1928, il., 204 p. (Traduzido pelo dr. Constantino dos Santos)

Ensaios II, c/ prefácio e os ensaios seguintes: o reino cadaveroso ou o problema da cultura em Portugal; as duas políticas nacionais; o clássico na educação e o problema do latim; a propósito dos «Ensaios Políticos» de Spencer; divagações pedagógicas a propósito de um livro de Wells. Lisboa, Seara Nova, 1929, 266 p., 2. ${ }^{a}$ ed. Publicações Europa-América, Lisboa 1957 (c/ novo ensaio intitulado: notas de esclarecimento). Ia ed. das Obras Completas, Lisboa, Livr. Sá da Costa, 1972, 299 p., 2a ed. idem, 1977

História de Portugal. Barcelona, Editorial Labor, S. A., 1929. "Coleccion Labor 206. $2^{\mathrm{a}}$ ed., 190 p. Barcelona, Editorial Labor S. A., 1958 «Coleccion Labor 206, com alterações ao texto da l.a $^{a}$ ed. não perfilhadas pelo autor, $166 \mathrm{p}$. Versão portuguesa com o título: Breve Interpretação da História de Portugal, Lisboa, Livr. Sá da Costa, 1971, 412 p.; $8^{\text {a }}$ ed. para a Secretaria de Estado da Cultura, em 1978, 125 p.

Antigona. Drama em três actos. Porto, Edição da República, 1930, $123 \mathrm{p}$.

Ensaios III, c/ prefácio e os ensaios seguintes: considerações sobre o problema da cultura; notas de literatura portuguesa - a Sulamita de Silva Gaio; o século XVIII por Ernani Cidade; Os Pescadores por Raul Brandão; Espanha por Antero de Figueiredo; Ressurreição por Manuel Ribeiro; A Língua Portuguesa por Jaime de Magalhães Lima; Literatura Portuguesa por Aubrey Bell; Fialho de Almeida por Castelo Branco Chaves; Literatura Portuguesa por Fidelino de Figueiredo; As Conferências do Casino por Alexandre Herculano; Antologia de E. de Queiroz por Agostinho de Campos. Notas de política - a reforma do legislativo; democracia e ditadura; o espírito dos partidos políticos; o espírito devaneador e a política; depois de uma ida ao parlamento; autonomia para uso externo e para uso interno; a formação de Portugal e a política; ainda a política do transporte e a política de fixação; teses integralistas; para a ressurreição de lázaro; sobre a aplicação política da ideia de igualdade; a reforma da instrução popular. Porto, Renascença Por- 
tuguesa, 1932, 428 p. $2 .^{\text {a }}$ ed., Lisboa, Seara Nova, 1937, 343 p. Nesta ed. foram suprimidos pelo autor os ensaios seguintes: A Língua Portuguesa, por Jaime de Magalhães Lima; Literatura Portuguesa, por Fidelino de Figueiredo; a Reforma da Instrução Popular, l.a ed. das Obras Completas, Lisboa, Livr. Sá da Costa, 1972, 313 p.; 2. ${ }^{\text {a }}$ ed. 1980

Le Portugal, s. a., s. e., s. d. Impresso na Ocogravura, L.da, C. d'Oliliveira L.da, R. Nova do Almada $532 .^{\circ}$, Lisboa, 156 p. índice: Le Pays, 1-25 pp.; Histoire, 26-57 pp.; Littérature, 58-95 pp.; Art, 96-112 pp.; Science et Enseignement, 115-135 pp.; Aperçu Économique, 136-145 pp.; Le Portugal et les Portuguais au-dela des Mers, 146-145 pp. (Publicado para a 28. ${ }^{\text {a }}$ reunião da Associaciation des Anatomistes, 10-12 de Abril de 1933, em Lisboa, por iniciativa do prof. Celestino da Costa que supomos ser o autor do artigo Science et Enseignement. Geografia, História, Literatura, Arte e referências coloniais pertencerão à pena de $\mathrm{A}$. S. Fica-nos uma dúvida sobre a autoria do capitulo Aperçu Economique)

Diálogos de doutrina democrática. Diálogo I: Da expressão do pensamento e da democracia. Diálogo 11: Da liberdade da autonaade e do socialismo. Diálogo III: Da reforma agrária. Diálogo IV: Do Maquiavelismo e do jesuitismo. Diálogo V: Da sociedade nova e do Estado Novo. Diálogo VI: Da opinião individual e da revolução cristã. S. d. - s. 1. - s. e. (obra proibida pela censura salazarista de que existem apenas três ou quatro exemplares, sem rosto), 1933?, 143 p. l.a ed. das Obras Completas, Lisboa, Livr. Sá da Costa, 1974, 393 p. (Obra incluida no vol. intitulado Democracia)

Aspecto do problema pedagógico em Portugal. Lisboa, Sociedade de Estudos Pedagógicos, 1934, 40 p.

Democracia. Lisboa, Seara Nova, 1934. «Estudos Políticos e Sociais». 2. a ed., Lisboa, Seara Nova, 1937. «Estudos Políticos e Sociais».

3. a ed., Lisboa, Seara Nova, 1938. «Estudos Políticos e Sociais» 1.a ed. das Obras Completas, Lisboa, Livr. Sá da Costa, 1974, 393 p. (este vol. inclui as obras: Diálogos de Doutrina Democrática, Alocução aos Socialistas no Banquete do $l .{ }^{\circ}$ de Maio de 1947 e Cartas do Terceiro Homem. Publicado também em opúsculo, col. Cadernos Livres n. ${ }^{\circ}$ 2, Livr. Sá da Costa, 1974, 29 p.)

Ensaios IV, c/ prefácio e os ensaios seguintes: questão prévia de um ignorante aos prefaciadores da lírica de Camões; em torno das ideias políticas de Camões; Camões panfletário; os dois Anteros; sobre o socialismo de Antero; Guilherme Meister, Cândido e Gonçalo Mendes Ramires; repercussões de uma hipótese- Ceuta, as navegações e a génese de Portugal. Lisboa,

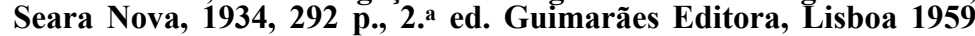
(c/ novo ensaio: laudas escritas para o segundo volume da «História de Portugal», 307 p., $1 .^{\mathrm{a}}$ ed. das Obras Completas, Lisboa, Livr. Sá da Costa, 1972, 289 p., 2.a ed. 1981

Em torno das ideias políticas de Camões, seguido de Camões Panfletário, opúsculo com os 2 ensaios de Ensaios $I V$. Lisboa, Livr. Sá da Costa, 1977, 63 p .

Ensaios $V$, c/ os ensaios seguintes: Oliveira Martins - a influência política do historiador. A significação política do publicista; a propósito de dois jesuítas; em torno da «ilusão revolucionária» de Antero; nótula sobre Nicolau Tolentino; apêndice ao ensaio sobre a lírica de Camões. Lisboa, Seara Nova, 1936, 301 p. $2^{\mathrm{a}}$ ed. Lisboa, Publicações Europa-América ,1955, 331 p., c/ no- 
vo ensaio: Glosas sobre o miguelismo de Oliveira Martins no «Portugal Contemporâneo». l. $^{\mathrm{a}}$ ed. das Obras Completas, Lisboa, Livr. Sá da Costa, 1973, 279 p.

Cartesianismo ideal e cartesianismo real. Seara Nova, 1937. «Estudos filosóficos e científicos», 45 p., 2. ${ }^{a}$ ed., Lisboa, Editorial inquérito, L.da s. d. (1959?), 45 p.

Em torno do problema da "Língua Brasileira". (Palavras de um cidadão do mundo, humanista crítico, a um estudante brasileiro seu amigo). Lisboa, Seara Nova, 1937, 35 p.

Introdução actual ao programa cooperatista. Lisboa, Seara Nova, 1937. «Estudos Políticos e Sociais», 30 p.

Sobre educação primária e infantil. Lisboa, Editorial Inquérito, L.da, 1939. Cadernos «Inquérito», 89 p.

Em torno da designação de "Monarquia Agrária» dada à primeira época da nossa história. Lisboa, Livraria Portugália, 1941, 69 p.

História de Portugal. Tomo I - Introdução geográfica. Lisboa, Livraria Portugália, 1941, 253 p. (esta obra foi também publicada c/ uma nova capa e c/ o título "Introdução Geográfico-Sociológica à História de Portugal, Lisboa, s. e., s. d., 253 p.). (Sobre as diferentes versões desta obra consultar a ed. das Obras Completas, Lisboa, Livr. Sá da Costa, 1973, que manteve o título: Introdução Geográfico-Sociológica à História de Portugal, 273 p.)

Um problema anteriano. (Sobre a ideia e a realidade do desprendimento activo na peregrinação moral do autor dos «Sonetos»). Lisboa, Ed. do Autor, s. d. (1943), 54 p.

Os dez anõezinhos da tia verde-água. (Texto redigido sobre um tema popular português). Lisboa, Editorial Ática, 1945, ilust., 18 p. $2^{\mathrm{a}}$ ed. Col. Obras Infantis de António Sergio, vol. I, Lisboa, Livr. Sá da Costa, 1978 (contém ainda os contos: O Ratão Pelado e A Cabana dos Lobos), 59 p.

Ensaios VI, c/ prefácio e os ensaios seguintes: Antero de Quental contra Oliveira Martins; o problema psicológico-moral em Eça de Queiroz; sobre a revoluçã̃o de 1383-85; a aspiração comum dos luso-descendentes; sobre cristianismo e cristãos, verdadeiros e falsos - a religião no oriente e no ocidente segundo Radhakrishnan; o jogral de Deus; em torno da expressão «civilização cristã»; a propósito do precedente artigo; resposta a um comentarista católico a alguns que julgam dever opor-se a Francisco de Assis e a Teresa de Avila; diante de um presépio. Lisboa, Editorial Inquérito, L.da, 1946, 289 p. l. $^{a}$ ed. das Obras Completas, Lisboa, Livr. Sá da Costa, 1971, 220 p.; 4. a ed. 1980

Alocução aos socialistas. Lisboa, Editorial Inquérito, L.da, 1947, 32 p.

l.a ed. das Obras Completas, Lisboa, Livr. Sá da Costa, 1974, 393 p. (obra incluída no vol. intitulado Democracia)

Antero de Quental e António Vieira perante a civilização cristã dos seus próprios tempos. Porto, Biblioteca Fenianos, 1948, 32 p. 2.a ed., com o título: Perante a inexistência de uma civilização cristã. Depoimentos de Antero de Quental e António Vieira. Lisboa, Editorial Inquérito, L.da, s. d. (1958?)

Confissões de um cooperativista. Lisboa, Editorial Inquérito, L.da, 1948, 2. a ed. Lisboa, Editorial Inquérito, L.da, s .d. (1957?)

Depoimento contra Depoimento. Lisboa, ed. dos Serviços Centrais da Candidatura, 1949, 7-43 pp. (prefácio de Mário de Azevedo Gomes contendo ainda: «Uma carta ao sr. dr. José de Magalhães»; «Testemunho» de João de Barros; «O conceito do homem livre, segundo o sr. Presidente do Conselho, e segundo nós» de Azevedo Gomes; «O Recurso ao Medo» de José Régio) 
Notas de esclarecimento com forçados lances de olhos sobre o moi Haïssable e alegações enjoativas Pro Domo Mea. Separata da revista Portucale, dos n.os 25-27 de Jan.-Junho, 1950 e 28-30 de Julho-Dez., 1950, Porto, s. e., 1950, 71 p.

Um caso típico da pseudo-cultura nacional. Lisboa, Editorial Inquérito, L.da, 1952, 8 p. 2. ${ }^{a}$ ed., Lisboa, Editorial Inquérito, L.da, s. d.

Cartas de problemática, dirigidas a um grupo de jovens amigos, alunas e alunos da Faculdade de Ciências. Lisboa, Editorial Inquérito, L.da, 1952-55, 12 fols.

Nota sumária sobre as minhas "heresias" epistemológicas. Separata da revista Lusíada, Porto, do n. ${ }^{\circ}$, vol. I, 1952. Opúsculo, s. d., 2 p.

Cartas do terceiro homem. Porta-voz das «Pedras vivas» do «País Real». Lisboa, Editorial Inquérito, L.da, 1953-57, 3 vols. $1^{\text {a }}$ ed. das Obras Completas, Lisboa, Livr. Sá da Costa, 1974, 393 p. (obra incluída no vol. intitulado Democracia)

Ensaios $V U$, c/ prefácio e os ensaios seguintes: I Glosas sobre algumas pègadas na areia do tempo: sobre a canção segunda de Camões; ainda sobre o carácter «congeminativo da lírica camoniana»; sobre o carácter do socialismo do Antero; sobre o apostolado cívico de Luiz Verney; sobre o problema da liberdade em André Gide; sobre o carácter da poesia de Teixeira de Pascoais; sobre o "Amor de Perdição»; sobre a universalidade do espírito de Viana da Mota. II Miudezas de música, de poesia, de cultura e de cinema: sobre cultura portuguesa; sobre as minhas reacções perante a música; sobre a interpretação de dois sonetos célebres; sobre o filme "Vida de Pasteur»; sobre o filme «Milagre em Milão». III Explicações a uma catedrático de direito sobre a doutrina ética dos meus «Ensaios». IV Relanços de doutrina democrática. $V$ Migalhas de filosofia em palestra amena com realistas comuns, com bergsonistas e com empiristas lógicos. VI Paideía (sugestões e conselhos de há mais de trinta anos). Lisboa, Publicações Europa-América. 1954, 315 p. $1 .^{a}$ ed. das Obras Completas, Lisboa, Livr. Sá da Costa, 1974, 246 p.

Antologia Sociológica. Trechos portugueses e estrangeiros seleccionados, comentados e prefaciados. Lisboa, Edição do Autor, 1956-57, 10 fols. Ia ed. das Obras Completas, Lisboa, Livr. Sá da Costa, 1978, 371 p. (inclui também a obra: Pátio das Comédias, das Palestras e das Prègações)

Pátio das comédias, das palestras e das prègações. Jornada primeira (a sexta), Lisboa. Editorial Inquérito, L.da, 1958, 6 fols. l.a ed. das Obras Completas, Lisboa, Livr. Sá da Costa, 1978, 371 p. (inclui também a obra: Antologia Sociológica)

Crimes perpetrados pela Editorial Labor na segunda edição da «História de Portugal». Lisboa, Editorial Inquérito, L.da, s .d. (1958?), $13 \mathrm{p}$

Divagações conjecturais sobre o antigo pastor montanhês do noroeste da Ibéria. Separata da «Revista de Guimarães», vol. 68, 1958, $20 \mathrm{p}$.

Ensaios VIII, c/ prefácio e os ensaios seguintes: despretenciosos informes sobre lusitanos e romanos; em torno da «História Trágico-Marítima»; sobre o socialismo de Oliveira Martins; nota preambular à "Teoria do Socialismo» de Oliveira Martins. Lisboa, Guimarães Editora, 1958, 285 p. Ia ed. das Obras Completas, Lisboa, Livr. Sá da Costa, 1974, 251 p.

Documento da candidatura à Presidência da República do General Humberto Delgado em 1958, 26 p. in: Eleições do Regime Fas- 
cista, $2 *$ ed. Lisboa, Presidência do Conselho de Ministros. Comissão do Livro Negro sobre o Fascismo. Dez. de 1979. (Protesto ao Presidente da República após as eleições de 1958)

Alocução no "Centro António José de Almeida". Lisboa, ed. do autor, s.d. (1958?), 6 p.

Documento resposta a uma nota do governo contra a acusação de impatriotismo por se pretender trazer a Portugal Aneurin Bevan. In: Missão em Portugal de Álvaro Lins. Rio de Janeiro, ed. Civilização Brasileira, S.A. 1960 (também assinado por: Humberto Delgado, Vieira de Almeida, Jaime Cortesão e Azevedo Gomes, 11 de Nov. 1958)

Sobre o espírito do cooperativismo. Lisboa, ed. do autor, (1958), 64 p.

O Cooperativismo. Objectivos $e$ modalidades. Lisboa, ed. do autor Círculo do Livro, s. d. (1958-60?)

Origem e evolução da nobreza. In Armoriai Lusitano. Genealogia e Heráldica. Lisboa, Editorial Enciclopédia, L.da, 1961

Canções de Bordo. In António Sérgio, Páginas de Recordações do seu tempo de Marinheiro. In Memoriam por Castelo Branco Chaves. Lisboa, Separata dos Anais do Clube Militar Naval, N. 1 a 3 Jan.-Março 1969, 8 p.

O conto de Eça de Queiroz O Tesouro, lido e comentado por António Sérgio, c/ uma nota de Castelo Branco Chaves. Separata da revista Ocidente, $n .^{\circ} 387$, Julho 1970,15 p.

NOTA: Das resenhas bibliográficas publicadas nas suas obras, consta um título: Quadros da Escola Francesa do Museu do Louvre. Trata-se de um trabalho feito no exílio para uma editorial Hispano-Americana. Desconhece-se o paradeiro do original e se foi, de facto, publicado. (Inform, de Castelo Branco Chaves)

\section{Ib COLABORAÇÃO EM PUBLICAÇÕES PERIODICAS}

AGROS - Boletim da Associação dos Estudantes de Agronomia e periódico de propaganda agrícola. Duração: 1917-1936. Local de publicação: Lisboa

Carta ao Director do "Agros" sobre a educação que nos falece, n. ${ }^{\circ}$, Jan. 1917, 18-27 pp.

Os Métodos do Regionalismo (Extracto de uma Conferência), n. ${ }^{\circ}$ 2-3, Mar. 1917, 60 p.

Ainda sobre os Métodos do Regionalismo, n. ${ }^{\circ}$ 4, Abr. 1917, 133-137 pp.

Notas e Comentários, n. ${ }^{\circ} 7$ e 8, Jul.-Ag. 1917, 247 e 248 pp.

A ÁGUIA_ órgão da Renascença Portuguesa. Director: Álvaro Pinto. Duração: 1911-1932. Local de publicação: Porto

Ao Infante Santo (poesia), l.a série (n. ${ }^{\circ}$ 5), Fev. 1911, 8 p.

De Noute (poesia), l. ${ }^{\mathrm{a}}$ série, (n. $\left.{ }^{\circ} 7\right)$, Mar. 1911, 15 p.

A ideação de Oliveira Martins, $2^{\text {a }}$ série (vol. I), 1912, 29-31 pp.

A lareira (poesia), 2. a série (vol. III), 1913, 13-15 pp.

Transfiguração, nos jardins de Kew, inverno, 2.a série, (vol. III), 1913, 83-84 pp.

Apostilha aos «Navegadores» (poesia), 2. a série, (vol. III), 1913, 133 p.

Epístolas aos Saudosistas - I, 2. a série, (vol. IV), 1913, 97-103 pp. 
Regeneração e tradição, moral e economia, 2. a série, (vol. V), 1914, 1-9 pp.

Pela pedagogia do trabalho, 2. a série, (vol. V), 1914, 95-96 pp.

Despedida de Julieta, 2. a série, (vol. V), 1914, 109-112 pp.

Os que sonham (poesia), 2. ${ }^{a}$ série, (vol. V), 1914, 147 p.

$O$ imperialismo de hoje e o imperialismo peninsular, $2^{\text {a }}$ série, (vol. V), 1914, 159-160 pp.

Explicações necessárias do Homem da Espada de Pau ao Arcanjo da Espada de um Relâmpago, 2. ${ }^{a}$ série, (vol. V), 1914, 170-175 pp.

O Self-Government na Escola, 2. a série, (vol. V), 1914, 187-189 pp.

O Self-Government na Escola I. Objecto e princípios do município escolar. Papel do professor, $2^{\mathrm{a}}$ série, (vol. VI), 1914, 25-29 pp.

O Self-Government na Escola II. Organização dos municípios escolares, 2.a série, (vol. VI), 1914, 58-64 pp.

O Self-Government na Escola III. A justiça e a disciplina. Os resultados, 2.a série, (vol. VI), 1914, 91-96 pp.

Pela Grei. No Mar das índias (poesia), 2a série, (vol. VI), 1914, 112-114 pp.

Phoibos Apollon (poesia), 2. a série, (vol. VI), 1914, 112-114 pp.

O Self-Government na Escola IV. Combinação do Self-Government $e$ do Self-Support. A junior republic., 2. a série, (vol. VI), 1914, 118-124 pp.

O Self-Government na Escola $V$. Combinação do Self-Government e do Self-Support. Razões que a recomendam para a escola portuguesa, 2. ${ }^{\mathrm{a}}$ série, (vol. VI), 1914, 157-160 pp.

A opinião americana perante a guerra, $2^{\text {a }}$ série, (vol. VII), 1915, 46-48 pp.

Carta a um amigo sobre a guerra, 2. a série, (vol. VII), 1915, 76-80 pp.

Divagaçóes a propósito de um livro, (A grei de Ezequiel de Campos), $2^{\mathrm{a}}$ série, (vol. VII), 124-128 pp.

Pela Grei. Nas Estrebarias de Augias (poesia), 2. a série, (vol. VII), 1915,179 p.

Prefácio de um livro (O Método Montessori de Luisa Sérgio), 2. a série (vol. VII), 1915, 253-255 pp.

Crítica à revista "Estúdio», 2 série, (vol. VIII), 1915, 44-46 pp.

Divagação a propósito de um livro, 2. a série, (vol. VIII), 1915, 73-79 p. (Trata-se do Ensaio sobre os factores essenciais do Império Britânico de Francisco Reis Santos)

Demitir, Separar... (Relendo alguns livros que vão citados), 2a série, (vol. VIII), 1915, 141-144 pp.

Notícia crítica ao livro "Obras Públicas de S. Tomé do Príncipe» de Ezequiel de Campos, 2. ${ }^{\text {a }}$ série, (vol. VIII), 1915, 175-176 pp.

Pela Grei (Anunciação) (poesia), 2.a série, (vol. IX), 1916, 58 p.

Pela Grei. Velando na Noite (poesia), 2.a série, (vol. X), 1916, 68-70 pp.

Um Programa, 2a série, (vol. X), 1916, 120-124 pp.

Ciência e educação, 2. a série, (vol. XI), 1917, 78-96 p.

Interpretação do Sebastianismo (A propósito da «Evolução do Sebastianismo" do sr. Lúcio de Azevedo), 2. ${ }^{\text {a }}$ série, (vol. XI), 1917, 179-184 pp.

Prefácio para uma tradução dos "Ensaios Políticos» de Spencer, 2. série, (vol. XII), 1917, 59-70 pp.

Aditamento aos "Espectros», 2. a série, (vol. XII), 1917, 153-157 pp.

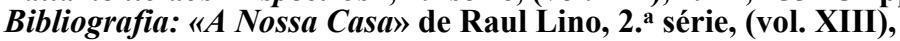
1918, 67-68 pp.

"O Princípio da Nacionalidade» de João Perestrello, 2a série, (vol. XIII), 69 p. 
Discurso imaginário. Pronunciado imaginariamente a uma imaginária assembleia dos que são chamados pelo Diário do Governo (em virtude de um conceito imaginário) «beneméritos da instrução pública», 2a série, (vol. XV), 1919, 23-27 pp.

Da necessidade de criar focos independentes para reforma da cultura por meio do recurso ao estrangeiro, 2. ${ }^{\mathrm{a}}$ série, (vol. XV), 1919, 140-147 pp.

A conquista de Ceuta (Ensaio de interpretação não romântica do texto de Azurara), 2.a série, (vol. XVII), 1920, 175-186 pp.

Manuel Bento de Sousa e a Oligarquia pedagógica em Portugal (A propósito do livro "O $\mathrm{Dr}$. Minerva»), 2." série, (vol. XVIII), 1920, 25-33 pp.

Notícia bibliográfica, 2a série, (vol. XVIII), 1920, 81-82 pp.

Aos estudantes promotores da trasladação dos restos mortais de Antero de Quental, 2a série, (vol. XIX), 1921, 52-55 pp.

O problema da cultura, 4. a série, (vol. I), 1928-30, 315-320 pp. (duas críticas literárias), $4^{\mathrm{a}}$ série, (vol. I), 1928-30, $95 \mathrm{p}$.

(duas notícias bibliográficas), 4. a série, (vol. I), 1928-30, 54 p.

Sobre a reforma do legislativo, $5^{a}$ série, $\left(\mathrm{n} .^{\circ} 1\right)$, Jan.-Fev. 1932, 1-7 pp.

Sobre um poemeto de Silva Gaio, $5^{\text {a }}$ série, (n. $\left.{ }^{\circ} 2\right)$, Mar.-Abr. 1932, 60-66 pp.

\section{ALMANAQUE DOS PALCOS E SALAS PARA 1926}

Lisboa, Livraria Popular de Francisco Franco

O verdadeiro palco da tragédia, 10 p.

\section{ANAIS DA ACADEMIA DE ESTUDOS LIVRES (1915-1916)}

Questões pedagógicas. Carta ao Director da Academia de Estudos Livres, 175 p.

2. Carta $e$ resposta de Almeida Lima, reitor da Universidade Lisboa, $191 \mathrm{p}$.

\section{ANAIS DO CLUBE MILITAR NAVAL}

Gráfico polar de desvios. Vol. 40, 17-19 pp., 1909 (artigo sobre técnica da navegação)

ANHEMBI - Director: Paulo Duarte. Local de publicação: S. Paulo, Brasil

A correspondência alegórica nos sermões de Vieira, n. ${ }^{\circ} 6$ (vol. II), Maio de 1951, 443-454 pp.

Sobre o carácter do socialismo de Antero, n. 21 (vol. VII), Ag. 1952, 428-443 pp.

AQUI E ALÉM - Revista de Divulgação Cultural. Director: Carlos A. Dias Ferreira. Duração: de Março de 1945 a Out. 1946. Números publicados: 5. Local de publicação: Lisboa

Explicação e subsunção sob fórmulas gerais, n. ${ }^{\circ}$ 3, Dez. 1945, 18-22 pp. 
ATLÂNTIDA - Mensário Artístico Literário e Social para Portugal e Brasil. Directores: João do Rio e João de Barros. Duraçã̃o: 1915-1919. Números publicados: 48. Local de publicação: Lisboa

Espectros, n. ${ }^{\circ} 11,15$ de Set. 1916, 1052-1067 pp.

$A$ educação cívica, a liberdade $e$ o patriotismo antigos $e$ modernos a propósito de Rousseau e de Camóes, n. ${ }^{\circ} 16,15$ de Fev. 1917, 250-260 pp.

A educação civica, a liberdade $e$ o patriotismo antigos $e$ modernos a propósito de Rousseau e de Camões, n. ${ }^{\circ}$ 17, 15 de Mar. 1917, 362-370 pp.

BOLETIM COOPERATIVISTA - Coordenado por António Sérgio Lisboa

Cooperativismo, n. ${ }^{\circ}$ 1, Fev. 1951, 1 p.

Busque o povo e o seu bem pela sua própria acção criadora; $O$ Problema da venda ao público (sob o pseudónimo de Carlos Poládio), . $^{\circ}$ 2, Maio 1951,1 .

A crítica no cooperativismo, n. ${ }^{\circ}$, Ag. 1951,1 p.

A marcha para o cooperativismo integral, n. ${ }^{4}$, Set. $1951,1-4$ pp.

A marcha para o cooperativismo integral, Fiscalização (sob o pseudónimo de Álvaro de Clarival), n. ${ }^{\circ}$ 5, Out. 1951, 1-2 pp., n. ${ }^{\circ} 6$, Nov. 1951.

Cooperativismo integral, n. ${ }^{\circ}$, Dez. 1951, 3 p.

Recapitulação ao fim de um ano, n. ${ }^{\circ}$ 9, Fev. 1952, 1, 2 e 6 pp.

Exemplo a seguir, n. ${ }^{\circ} 13$, Out. 1954, 2 p.

O espírito cooperativo $e$ a prática do retorno diferido, $n .^{\circ} 16$, Jan. 1955,3 p.

No quarto aniversário deste "Boletim», $O$ cooperativismo e o Estado, n. ${ }^{\circ} 17$ Fev. 1955, n. ${ }^{\circ} 25$, Out. 1955

Glosa, n. ${ }^{\circ}$ 26, Nov. 1955, 1 p.

Glosa, n. ${ }^{\circ}$ 27, Dez. 1955, 1-4 pp.

Glosa, n. ${ }^{\circ}$ 28, Jan. 1956, 2 p.

No quinto aniversário deste «Boletim», n. ${ }^{\circ} 29$, Fev. 1956, 1 p.

Glosa, n. ${ }^{\circ}$ 29, Fev. 1956, 2 p.

Glosa, n. ${ }^{\circ}$ 30, Março 1956, 1 p.

Que deverá ser de futuro o "Boletim», um órgão de doutrina, uma folha recreativa, ou uma combinação das duas coisas?, n. ${ }^{\circ} 34$, Jul. 1956, 1 p.

Aspectos do sector cooperativo, n. ${ }^{\circ}$ 40-41, Jan.-Fev. 1957, 1-2 pp.

Em torno da ideia de aliança cooperativa internacional, Cooperativas de abono e crédito, ${ }^{\circ}{ }^{\circ} 46$, Jul. 1957, 4 p.

Sobre o ideal da criação de um sector cooperativo, n. ${ }^{\circ}$ 52, Jan. 1958, 1-4 pp.

Entrevistando António Sérgio, n. ${ }^{\circ}$ 53, Fev. 1958, 1 p.

Cooperativismo e reforma moral e cultura, n. ${ }^{\circ} 58$, JuL 1958, 4-6 pp.

Notas sobre Caixas Cooperativas de Aforro e de Crédito, n. ${ }^{\circ}$ 63, Dez. 1958, 1-6 pp.

Nota, n. $^{\circ} \quad 65$, Fev. 1959, 8 p.

Nota,.$^{\circ} \quad 66$, Mar. 1959, 7 p.

Nota, n. ${ }^{\circ}$ 67, Abr. 1959, 8 p.

Nota, n. ${ }^{\circ}$ 68, Maio 1959, 3 p. 
BOLETIM INFORMATIVO PARA AS COOPERATIVAS DO CONSELHO CENTRAL DAS COOPERATIVAS DE LISBOA E ARREDORES. Rua Voz do Operário 64, $10^{\circ}$ Lisboa. (Boletim Policopiado). Duração: Julho de 1947 a Dez. de 1948. Números publicados: 16

Publica 4 palestras radiofónicas proferidas nos microfones do «Club Radiofónico de Portugal»

1. a palestra - N. ${ }^{\circ} 1$ Julho de 1947

2. a palestra - N. ${ }^{\circ} 2$ Set. de 1947

3. a palestra - N. ${ }^{\circ} 6$ Março de 1948

4. ${ }^{a}$ palestra $-\mathrm{N} \cdot{ }^{\circ} 7$ Abr. de 1948

BOLETIM DA SOCIEDADE LUSO-AFRICANA DO RIO DE JANEIRO - Rio de Janeiro. Duração: 1931-1938. Comissão directiva: António de Sousa Amorim, Domingos José Veloso e Francisco das Dores Gonçalves

Nota apensa a uma fotografia do dr. Álvaro de Castro, n. ${ }^{\circ}$ Abr., Maio, Jun. de 1933, 25 p.

Problemas coloniais e problemas metropolitanos, n. ${ }^{\circ}$ 24, Dez. 1938, $36 \mathrm{p}$.

CADERNOS DE POESIA — Lisboa. Duração: 1940-1953. Números publicados: 15

Número dedicado a Teixeira de Pascoaes, III serie, fase. 14, 1953, 11 p.

CAMILIANA \& VÁRIA - Revista Boletim do Círculo Camiliano. Director: Aquilino Ribeiro. Duração: de Jan. de 1951 a Maio de 1954. Números publicados: 7. Local de publicação: Lisboa

Monólogo do vaqueiro ou notazinha problemática sobre o "Amor de Perdição», n. ${ }^{\circ}$ 1, Jan.-Março 1951, 2-4 pp.

A CAPITAL-(Suplemento de literatura e arte)

António Sérgio, um inédito: Retrato do Almirante Carlos Napier. 21 de Jan. 1970, (c/ uma nota de Castelo Branco Chaves)

CLARIDADE - Revista de Literatura. Director: Carlos Bastos. Números publicados: 3. Local de publicação: Porto

Em face da literatura contemporânea actual, n. ${ }^{\circ}$, Mar. de 1929, 11 p.

\section{COLECÇÃO OFICIAL DE LEGISLAÇÃO PORTUGUESA}

Decreto 9.332 - cria no Ministério da Instrução Pública um organismo técnico permanente que se denominará Junta de Orientação dos Estudos. 29 Dez. 1923,549 p.

Decreto 9.333 - cria em Lisboa o Instituto Português para o Estudo do Cancro. 29 Dez., 1923, 549-550 pp.

O COMÉRCIO DO PORTO-(Suplemento n. ${ }^{\circ} 22$ Cultura e Arte)

«O problema da afluência nos liceus», 11 de Out., 1955 
DESCOBRIMENTO - Revista de Cultura. Director: João de Castro Osório. Duração: 1931-1932. Números publicados: 7. Local de publicação: Lisboa

Guilherme Meister, Cândido e Gonçalo Mendes Ramires, n.os 6 e 7, 1932, 180-190 pp.

O DIABO - Semanário de Literatura e Critica. Directores: Adolfo Barbosa, Artur Inez, Ferreira de Castro, Guilherme Morgado, Joaquim Madureira, José Antunes Carvalho, Manuel Campos Lima e Rodrigues Lapa. Duração: 2 de Jun. de 1934 a 21 de Dez. de 1940. Números publicados: 326. Local de publicação: Lisboa

Dissertação sobre música popular, ${ }^{\circ}{ }^{60}, 18$ de Ag. 1935, 1-6 pp.

Barroquismo, cultismo e conceptismo, n. ${ }^{\circ}$ 95, 19 de Abr. 1936, 1-8 pp.

Do barroquismo parenético pelos "conceitos predicáveis», n. ${ }^{\circ} 98,10 \mathrm{de}$ Maio 1936, 1-8 pp.

Diálogo de mortos. Fedra, n. ${ }^{\circ} 105,28$ de Jun. 1936, 16 p.

Uma carta sobre bibliotecas públicas, n. ${ }^{\circ} 108,19$ de Jul. 1936, 1 p.

Sobre uma opinião de Raúl Proença, n. ${ }^{112}, 16$ de Ag. 1936, 1 p.

Uma carta a propósito de bibliotecas públicas, $n{ }^{\circ} 115,6$ de Set. 1936, 1 p.

Resposta a Sant'Ana Dionísio. Relembrando que o assunto era a seriedade de pensamento, $\mathrm{n} .^{\circ} 116,13$ de Set. $1936,1-5 \mathrm{pp}$.

Procurando desembaraçar uma meada e dissipar um nevoeiro, $n .^{\circ} 119$, 4 de Out. 1936, 3 e 7 pp.

Procurando desembaraçar uma meada e dissipar um nevoeiro mental, n. ${ }^{\circ} 120,11$ de Out. 1936,3 p.

Procurando desembaraçar uma meada e dissipar um nevoeiro mental, n. ${ }^{\circ} 121,18$ de Out. 1936,2 p.

Procurando desembaraçar uma meada e dissipar um nevoeiro mental, n. ${ }^{\circ} 122,25$ de Out. 1936, 6-7 pp.

Resposta não ao panegirista de Leonardo Coimbra mas a três leitores que se me dirigiram, $n .^{\circ} 129,13$ de Dez. 1936, 7 p.

Em que trabalham os nossos escritores, (inquérito), n. ${ }^{\circ} 149,2$ de Maio 1937, 5 p.

Carta a Abel Salazar, n. ${ }^{\circ}$ 157, 27 de Jun. 1937, 11 p.

Segunda carta a Abel Salazar, n. ${ }^{\circ} 158,4$ de Jul. 1937, 7 p.

(Carta de António Sérgio a propósito do artigo de Mário Ramos: "Para a crítica do crítico António Sérgio»), n. ${ }^{\circ}$ 165, 21 de Nov. 1937, 5 p.

A pena de morte (depoimento), $\mathbf{n} .^{\circ}$ 174, 23 de Jan. 1938, 1 p.

O antagonismo interno no cristianismo histórico, $n .^{\circ} 222,24$ de Dez. 1938, 1 p.

Resposta a uma consulta, $.^{\circ} 231,25$ de Fev. 1939

O "Espaço Vital» e a abundância agrícola, n. ${ }^{\circ} 241,6$ de Maio 1939, 1 e 4 pp.

A ciência, o progresso social e o regime do lucro, $n .^{\circ} 246,10$ de Jun. 1939, 1-8 pp.

Sobre a agrobiologia ou ciência da agricultura da abundância, n. ${ }^{\circ} 248$, 24 de Jun. 1939, 3 p.

Sobre a agrobiologia ou ciência da agricultura da abundância, n. ${ }^{\circ} 250$, 8 de Jul. 1939, 3 e 8 pp.

Sobre a agrobiologia ou a ciência da agricultura da abundância, n. ${ }^{\circ}$ 252, 22 de Jul. 1939, 1 e 4 pp. 
Sobre a agrobiologia ou a ciência da agricultura da abundância, n. ${ }^{\circ}$ 254, 5 de Ag. 1939, 2 e 6 pp.

Sobre a agrobiologia ou a ciência da agricultura da abundância, n. ${ }^{\circ} 256$, 19 de Ag. 1939, 7 p.

As surpresas agradáveis da viagem. Uns reparos de biologista e uma fantasia hidropónica I, $\mathrm{n} .{ }^{\circ} \mathbf{2 5 8 ,} 2$ de Set. 1939, 3 p.

As surpresas agradáveis da viagem. Uns reparos de biologista e uma fantasia hidropónica, $n .^{\circ} 259,9$ de Set. 1939, 7 p.

Problemas da abundância. Em torno de uma decisão do governo inglês, n. ${ }^{\circ} 261,23$ de Set. 1939,1 p.

Uma entrevista com António Sérgio, n. ${ }^{\circ} 279,27$ de Jan. 1940, 3 e 7 pp.

A paixão de Pedro o Cru: mera emotividade ou tragédia humana?, n. ${ }^{\circ} 285,9$ de Mar. 1940, 1 e 6 pp.

Dialoguete, Angelo e Policiano, n. ${ }^{\circ} 287,23$ de Mar. 1940, 3 p.

Crítica literária e crítica social, $n .^{\circ} 293,4$ de Maio 1940, 1 e 6 pp.

O genio inglês e a planificação da economia, n. ${ }^{\circ} 297,1$ de Jun. 1940,3 p.

Paixão e calvário das letras portuguesas. Uma carta de A.' Sérgio, n. ${ }^{\circ} 300,22$ de Jun. 1940, 2 p.

Evoluçấo económico-social da nação portuguesa, n. ${ }^{\circ} 301,29$ de Jun. 1940,3 p.

Recapitulação, n. ${ }^{\circ}$ 306, 17 de Ag. 1940, 1-2 pp.

Resposta a um irmão católico, n. 308,17 de Ag. 1940, 6 p.

Ainda ao irmão católico, n. ${ }^{\circ} 311,7$ de Set. 1940,6 p.

Incompreensão do portuguesinho valente perante a mulher estrangeira do nosso tempo, n. ${ }^{\circ} 325,14$ de Dez. 1940, 1-5 pp.

\section{DIÁRIO DE LISBOA}

A influência da Águia no movimento literário português, 29 de Jun., 1935

Carta a um jovem, (ref. a um artigo de A. S. saído na Seara Nova c/ o mesmo título), de Set., 1937

António Sérgio declara-nos que votará em Quintão Meireles porque este candidato promete liberdade ao país, 12 de Jul., 1951

Uma carta de António Sérgio a propósito de uma crítica que lhe fizeram no Diário da Manhã, 16 de Jul., 1951

Para além das eleições o escritor António Sérgio esclarece as razões porque não se propôs a deputado, 12 de Out., 1953

António Sérgio declara-nos que o acto eleitoral serviu aos oposicionistas para actualizar a sua experiência e refazer a consciência cívica do país, 10 de Nov., 1953

A cultura portuguesa, 30 de Maio, 1956

Um esclarecimento (a propósito das declarações pronunciadas na sede do Comando Geral da Legião Portuguesa), 16 de Nov., 1956

António Sérgio esclarece os propósitos da Comissão Promotora do Voto, na qual diz que desejaria ver monárquicos e até elementos da União Nacional nas listas da Oposição, 23 de Jan., 1957

Posições e objectivos da Comissão de Voto, reafirmados por António Sérgio, 21 de Mar., 1957

António Sérgio expõe as razões do seu apoio à candidatura do general Humberto Delgado e esboça uma crítica do Corporativismo, 9 de Maio, 1958

O I Congresso de Escritores Portugueses está em organização, afirma Sérgio, 10 de Out., 1958 
DIÁRIO LIBERAL - Jornal Republicano da Manhã. Director: Evaristo de Carvalho. Duração: 1932-33. Local de publicação: Lisboa

Do que se diz e do que se escreve, 13 de Maio, 1933

Do que se diz e do que se escreve, 16 de Maio, 1933

Do que se diz e do que se escreve, 4 de Jun., 1933

A liberdade e a pedagogia, 14 de Jul., 1933

Política Democrática, 3 de Jan., 1934

Política Experimental, 5 de Jan., 1934

Democracia Crítica, 12 de Jan., 1934

EDUCAÇÃO SOCIAL - Revista de Pedagogia e Sociologia. Director: prof. Adolfo Lima. Duração: 1924-1927. Local de publicação: Lisboa

Coeficiente de assimetria dos indivíduos, $\mathrm{n} .^{\circ} 1$ (l. ${ }^{\circ}$ ano), $10 \mathrm{Jan}$. 1924, 11-13 pp.

Sobre a educação dos sentidos e dos músculos, n. ${ }^{\circ} 12$ (1. ${ }^{\circ}$ ano), 25 Jun. 1924, 207-208 pp.

A obra do professor Bensaúde no Instituto Superior Técnico, n. ${ }^{\circ} 6$ (2. ${ }^{\circ}$ ano), 15 de Jun. 1925, 174-177 pp.

Liga Propulsora de Instrução, n. 1 (3. ano), 15 Jan. 1926, 12-14 pp.

Nota para um estudo sobre as ideas pedagógicas de Eça de Queiroz, n. ${ }^{\circ}\left(3 .^{\circ}\right.$ ano $), 15$ Abr. 1926, 114-115 pp.

O ESTADO DE S. PAULO - (Brasil)

«Sobre as ideias filosófico-sociais em Os Possessos de Dostoiewsky (a propósito de um livro recente)» 15 e 16 de Jul. de 1947. (O livro referido intitula-se: Algumas notas sobre Os Possessos de Dostoiewsky. Lisboa, ed. Ática, 1947, 69 p. autor: Pedro Nascimento)

GLEBA - Semanário de Literatura e Crítica

Um problema pedagógico, 4 de Dez., 1934, 1 p.

GUIA DE LEITORES - Notas Críticas de Bibliografia Moderna. Director: Agostinho da Silva. Local da publicação: Lisboa

(Nota crítica à obra: "La Turquie, Passé et Présent» de Marcel Clerget, $n .^{\circ} 213$ da Collection Armand Colin), fasc. $1^{\circ}$ (1941) s/data, 14-17 pp.

HOMENS LIVRES - Livres da Finança e dos Partidos. Red. Princ.: A. Sérgio. Ed. Reynaldo dos Santos. Números publicados: 2. Local de publicação: Lisboa

Vivos e mortos, n. ${ }^{\circ} 1,1$ Dez. 1923, 1-2 pp.

O tropel dos escravos (poesia), n. ${ }^{\circ} 1,1$ Dez. 1923, 6-7 pp.

Decadência física e apatia moral, $n .^{\circ} 2,12$ Dez. 1923, 8-9 pp. 
COMENTÁRIOS:

Conferências e exposiç̃̃es, n. ${ }^{\circ} 1,1$ Dez. 1923,16 p.

Lapsos e mal entendidos, $\mathrm{n} .{ }^{\circ} 2,12$ Dez. 1923, 15-16 pp.

A Pátria, n. ${ }^{\circ}$ 2, 12 Dez. 1923, 15-16 pp.

Hospitalidade, $.^{\circ} 2,12$ Dez. 1923, 15-16 p.

JORNAL DE LETRAS E ARTES - Director: Azevedo Martins. Duração: 1961-1968. Números publicados: 267. Local de publicação: Lisboa

A investigação nas Universidades e a preparação Liceal, n. ${ }^{\circ} 101,4$ Set. de 1963, 1-4 pp.

LER - Jornal de Letras Artes e Ciências. Editor: Publicações Europa-América. Duração: 1952-1953. Números publicados: 18. Local de publicação: Lisboa

Escritores, artistas e editores dizem o que pensam da publicação deste jornal. (Depoimento de A. Sérgio), n. ${ }^{\circ}$ 1, Abr. de 1952, 1-2 pp.

A propósito de Camóes. A crítica literária, a história da literatura e a biografia dos autores, $\mathrm{n} .^{\circ}$ 3, Jun. de 1952, 6 p.

Resposta a um inquérito, $n .^{\circ} 18$, Set. de 1953

LUSÍADA - Revista Ilustrada de Cultura, Arte, Literatura, História, Crítica. Director: Carlos de Passos. Duração: 1952-1960. Números publicados: 12. Local de publicação: Porto

Nota sumária sobre as minhas «Heresias Epistemológicas», n. ${ }^{\circ}$, (vol. I), Primavera de 1952, 18-19 pp.

LVSITANIA - Revista de Estudos Portugueses. Director: Carolina Michaëlis de Vasconcelos. Duração: 1924-1927. Números publicados: 10. Local de publicação: Lisboa

Comentários críticos das seguintes obras:

Espanha, de Antero de Figueiredo, fase. 1 (vol. I), Jan. 1924, 106-110 pp.

O Heroísmo, a Elegância, o Amor, de Júlio Dantas, fase. 1 (vol. I), Jan. 1924, 110-111 pp.

Fialho de Almeida, de Castelo Branco Chaves, fase. 1 (vol. I), Jan. 1924, 111-114 pp.

A Língua Portuguesa e os Seus Mistérios, de Jaime de Magalhães Lima, fase. 1 (vol. I), Jan. 1924, 119-121 pp.

Ensaio sobre a Psicologia da Intuição, de Faria de Vasconcelos, fase. 1 (vol. I), Jan. 1924, 140-142 pp.

Os Pescadores, de Raul Brandão, fase. 2 (vol. I), Mar. 1924, 255-259 pp.

Ressurreição, de Manuel Ribeiro, fase. 2 (vol. I), Mar. 1924, 262-269 pp.

História da Literatura Clássica, de Fidelino de Figueiredo, fase. 2 (vol. I), Mar. 1924, 279-287 pp.

O Seiscentismo em Portugal, de Manuel Múrias, fase. 3 (vol. I), Jun. 1924, 441-446 pp.

Episódios Dramáticos da Inquisição Portuguesa, de António Baião, fase. 3 (vol. I), Jun. 1924, 446-448 pp. 
(NOTA: - O «erratum» da pág. 491, fase. 3 de Jun. 1924, desmente a autoria de um comentário saído com a assinatura de A. Sérgio)

Alguns Aspectos da Literatura Portuguesa, de Aubrey Bell, fase. 1 (vol. II), Set. 1924, 96-100 pp.

Contos e Lendas da Nossa Terra, de Maria da Luz Sobral, fase. 1 (vol.

II), Set. 1924, 122 p.

Uma carta de Jaime Magalhães Lima, fase. 1 (vol. II), Set. 1924, 122-127 pp.

As duas políticas nacionais, fase. 7 (vol. Ill), Out. 1925, 63-72 pp.

Comentário crítico da obra:

História de Arzila durante o domínio português, de David Lopes.

Coimbra, 1925, fase. 7 (vol. III), Out. 1925, 101-103 pp.

As duas políticas nacionais, fase. 7 (vol. III), Out. 1925, 63-72 pp.

Comentário crítico da obra:

A tomada e Ocupação de Ceuta, de Jaime Cortesão, fase. 9 (vol. III), Abr. 1926, 446-451 pp.

MUNDO LITERÁRIO - Semanário de Crítica e Informação Literária, Científica e Artística. Director: Jaime Cortesão Casimiro. Duração: de 11 de Maio de 1946 a 1 de Maio de 1948. Números publicados: 53. Local de publicação: Lisboa

A propósito de uma discussão entre Antero de Quental e Oliveira Martins, n. ${ }^{\circ}$ 37, 18 Jan. de 1947, 1-2 p.

\section{NOTÍCIAS DE HUÍLA}

Do capitalismo de competição para o capitalismo de monopólio, 13 de Nov., 1937

Gualdim Pais, 15 de Fev., 1938

OCIDENTE - Revista Portuguesa Mensal. Director: Álvaro Pinto. Local de publicação: Lisboa

A acção de Álvaro Pinto na «Renascença Portuguesa», n. ${ }^{\circ} 226$ (vol.

III), Fev. de 1957, 39-41 pp.

O Conto de Eça de Queiroz «O Tesouro» lido e comentado por A. Sérgio, n. ${ }^{\circ}$ 387, Jul. 1970, 3-15 pp.

PELA GREI - Revista para o Ressurgimento Nacional pela Formação e Intervenção de Uma Opinião Pública Consciente. Director: António Sérgio. Duração: 1918-1919. Números publicados: 7 números e um Suplemento. Local de publicação: Lisboa

NO CORPO DA REVISTA:

Do Intuito e natureza desta revista, n. ${ }^{\circ} 1,1918,1-9$ pp.

Da opinião pública e da competência em democracia, n. ${ }^{\circ} 1,1918$, 46-53 pp. 


\section{COMENTÁRIOS:}

Sinais de desorientação. O Monumento ao Marquês de Pombal, n. ${ }^{\circ}$, 1918, $71-72$ pp.

Mais desnorteamento. Extensão universitária e conferências para o povo, n. ${ }^{\circ} 1,1918,72-73$ pp.

Um livro para a regeneração dum povo: "La Nouvelle Cité de France", por Henri Mazel, n. ${ }^{\circ} 1,1918,73-75$ pp.

BIBLIOGRAFIA:

Contra um plágio do Dr. Teófilo Braga pelo Dr. Ricardo Jorge. Lisboa, $1917,{ }^{\circ}{ }^{\circ}, 1918,75-78$ pp.

NO CORPO DA REÍVISTA :

Insistindo...., n. ${ }^{\circ}$ 2, Maio de 1918, 81-82 pp. (não assinado)

Alexandre Herculano e o problema moral e social do Portugal moderno, . $^{\circ}$ 2, Maio de 1918, 111-119 pp.

COMENTÁRIOS:

Ainda o caso Pombal, n. ${ }^{\circ}$, Maio de 1918, 137-138 pp.

Em torno do problema da educação popular, n. ${ }^{\circ}$ 2, Maio de 1918, 138- 139 pp.

Os católicos portugueses e a sua organização, n. ${ }^{\circ}$, Maio de 1918, 139- $140 \mathrm{pp}$.

Representação profissional, ${ }^{\circ}{ }^{\circ}$, Maio de 1918, $141 \mathrm{p}$.

NO CORPO DA REÍVISTA:

Em ferro frio?...., n. ${ }^{\circ}$ 3, Julho de 1918, 147 p. (não assinado) ${ }^{\wedge}$

A situação moral e social. A escola portuguesa, órgão parasitário; Necessidade da sua reforma sob a idea directrix do trabalho produtivo, $\mathrm{n} .^{\circ}$ 3, Julho de 1918, 169-178 pp.

COMENTÁRIOS :

Revista e revistas, $n .^{\circ}$ 3, Julho de 1918, 179-187 pp.

Um apelo e um problema; têm a palavra as elites dirigentes,.$^{\circ} 3$, Julho de 1918, 186-187 pp.

Exemplos do estrangeiro, n. ${ }^{\circ}$, Julho de 1918, 187-188 pp.

Os estudantes $e$ o partidarismo político, n. ${ }^{\circ} 3$, Julho de $1918,188-189$ pp.

Por um programa de ressurgimento nacional, $n .^{\circ} 3$, Julho de 1918, 189 p. (não assinado)

BIBLIOGRAFIA:

Leivas da minha Terra, por Ezequiel de Campos. 1918. Porto, n. ${ }^{\circ} 3$, Julho de 1918, 189-191 pp.

NO CORPO DA REÍVISTA :

Da necessidade de as elites fazerem uma revolução pacífica, n. ${ }^{\circ} 4,2$ de Out., 1918, 193-196 pp. (não assinado)

A situação moral e social. A escola portuguesa, órgão parasitário; $\mathrm{Ne}$ cessidade da sua reforma sob a idea directrix do trabalho produtivo, $n .^{\circ} 4,2$ de Out., 1918, 210-222 pp. 
COMENTÁRIOS:

Na igreja portuguesa, n. ${ }^{\circ}$ 4, 2 de Out., 1918, 225-227 pp.

$A$ "Nova Geração», n. ${ }^{\circ} 4,2$ de Out., 1918, $227-228$ pp.

O relatório da sub-comissão do partido laborista inglês, n. ${ }^{\circ} 4,2$ de Out., 1918, 228-232 pp.

BIBLIOGRAFIA:

A Evolução e a Revolução Agrária, por Ezequiel de Campos. Porto, 1918, n. ${ }^{\circ}$ 4, 2 de Out., 1918, 232-236 pp.

NO CORPO DA REVISTA:

Dextrígrados e Sinistrígrados, n. ${ }^{\circ}$ 5, 14 de Dez. 1918, 237-239 pp. (não assinado)

A Situação Moral e Social. O "Morbo Gaulês», n. ${ }^{\circ}$ 5, 14 de Dez., 1918, 265-269 pp.

COMENTÁRIOS :

A crise económica, n. ${ }^{\circ}$ 5, 14 de Dez. 1918, 272-273 pp.

$A$ superstição da matéria em pedagogia, n. ${ }^{\circ}$ 54, 14 de Dez. 1918, 273-274 pp.

Bibliografia, n. ${ }^{2}$, 14 de Dez. 1918, 274-280 pp. (não assinado)

NO CORPO DA REVISTA:

Breves anotações pedagógicas à última reforma de instrução secundária, n. ${ }^{\circ}$, Março de 1919, 290-309 pp.

COMENTÁRIOS:

Sobre o nosso «Esboço de um programa de fomento», $n .^{\circ} 6$, Março de 1919, 319-320 pp.

Reforma de instrução, n. ${ }^{\circ}$, Março de 1919, 320 p.

NO CORPO DA REVISTA:

Para um plano de política nacional. A redacção de Pela Grei submete à Nação o seguinte esboço de um programa de fomento, Suplemento n. ${ }^{\circ}$, (11 p.)

NO CORPO DA REVISTA:

A função do político e a política nacional, n. ${ }^{\circ}$ 7, 1919, 321 a 324 pp.

COMENTÁRIOS:

Reforma da instrução, n. ${ }^{\circ} 7,1919,353$ a 356 pp.

Mocidade académica, $\mathrm{n} .^{\circ} 7,1919,359$ a $362 \mathrm{pp}$.

PIM PAM PUM! - Suplemento Infantil de «O Século». N. ${ }^{\circ}$ 1, Dez. de 1925

História do Lobo e dos Cabritinhos (De um conto popular francês) 5 de Jan. 1926. 4 e 5 pp. 
PORTUCALE - Revista Ilustrada de Cultura Literária, Cientifica e Artística. Directores: Augusto Martins, Cláudio Basto, Pedro Vitorino. 1945 - Pina de Moraes e Veiga Pires. Duração: 1928-1955. Local de Publicação: Porto

A religião no oriente $e$ no ocidente segundo Radhakrishnan, $n .{ }^{\circ} 1$, (vol. I), Fev. de 1946, 6-13 pp.

Inteligência e emoção nos poemas e nos leitores (trecho de um prefácio inédito), n. ${ }^{\circ}$ 7-9, (vol. II), Jan.-Jun. de 1947, p. 32-35

Notas de esclarecimento I-Com forçados lances de olhos sobre o "Moi Haïssable» e alegações enjoativas «pro domo mea", n. ${ }^{\circ} 25-$ -27, (vol. V), Jan.-Jul. de 1950, 18-32 pp.

Notas de esclarecimento II - Com forçados lances de olhos sobre o "Moi Haüssable» e alegações enjoativas «pro domo mea", n. ${ }^{\circ} 28-$ -30, (vol. V), Jul.-Dez. de 1950, 193-244 pp.

Sobre a minha colaboração na obra da "Renascença Portuguesa", n. 3, (vol. I), Primavera de 1955, 115-123 pp.

\section{REPÚBLICA}

O 31 de Janeiro e um dito do Sebastião do Quiosque da Praça Nova, 30 de Jan., 1946

O dr. António Sérgio entrevistado pela República defende a mais completa liberdade individual e considera necessária a planificação económica, 10 de Jan., 1947

Um trecho da antologia de prosa doutrinal de autores portugueses, 18 de Mar., 1947

Confissões de um cooperativista, (Conferências de A. S. na Caixa Económica Operária em 25 de Nov.)

António Sérgio fala à República sobre o movimento cooperativo português, 4 de Jun., 1948

O Apóstolo e o Político, 27 de Jun., 1948

Quem quer República deve não ser simplista e contar com os demais, 4 de Out., 1948

Eu posso fazer um depoimento. Comentário a certos conceitos políticos à luz da minha experiência pessoal, n. ${ }^{\circ}$ 1, 9 de Jan., 1949 (Continuação: $n .^{\circ} 2-10$ de Jan.; n. ${ }^{\circ} 3-11$ de Jan.; n. 4 12 de Jan.; n. ${ }^{\circ} 4$ - repetido em 13 de Jan. por ter saído truncado no n. ${ }^{\circ}$ anterior; $n .^{\circ} 5-14$ de Jan.; n. 6 - 15 de Jan.; n. ${ }^{\circ} 7$ - 16 de Jan.; n. ${ }^{\circ} 7$ a -17 de Jan.; n. ${ }^{\circ} 8-27$ de Jan.; n. ${ }^{\circ} 9-28$ de Jan.; $n .^{\circ} 10-29$ de Jan.; n. ${ }^{\circ} 10$ a -30 de Jan.; n. ${ }^{\circ} 11$ - 1 de Fev.; n. ${ }^{\circ} 12-2$ de Fev.; n. ${ }^{\circ} 13-3$ de Fev.)

Do espírito barroco, 30 de Jun., 1949

Relanços de vulgarização sobre cooperativismo, 4 de Jul., 1949

(Continuação: 11 de Jul.; 18 de Jul.; 25 de Jul.; 1 de Ag.; 8 de

Ag.; 15 de Ag.; 22 de Ag. 29 de Ag.; 5 de Set.; 12 de Set. e 19 de Set.)

Humanismo e valor do espírito, coisismo e valor das coisas, 11 de Nov., 1949

Desporto competitivo - negociata e alheamento do espírito, 8 de Jun., 1951

Ginástica educativa e interesse pelo desporto competitivo profissional, 21 de Jun., 1951

Nacionalismo verdadeiro e compreensivo. Nacionalismo falso e perseguidor, 10 de Jul., 1951

Os requisitos do verdadeiro espírito democrático, 12 de Jul., 1951 
Pontos e contrapontos (em torno da afirmação de alguns oradores), 14 de Jul., 1951

Ponto e contraponto (em torno de afixação de cartazes), 18 de Jul., 1951

Pontos e contrapontos, 20 de Jul., 1951

Em torno da noção de Ligas Cívicas, 30 de Jul., 1951

Cartas do aprendiz de pedagogo I, 2 de Jun., 1953

(Continuação: II -11 de Jun.; III -17 de Jun.; IV -25 de Jun.; V -29 de Jun.; VI -6 de Jul.; VII -15 de Jul.; VIII 29 de Jul.; IX -6 de Ag.; X -13 de Ag.; XI -18 de Ag.; XII -25 de Ag.; XIII -3 de Set.; XIV -9 de Set.; XV 15 de Set.)

Transcrição de um artigo sobre o filme Milagre em Milão de Vitorio de Sicca, do Noticias de Lourenço Marques, 27 de Jul., 1953

Com o país liberto do medo combatamos pela decência e pela veracidade de todas as operações do escrutínio, diz-nos Sérgio, 7 de Out., 1953

Com o recenseamento como foi feito e o medo que tolhe os cidadãos portugueses nenhum candidato independente pode ter esperanças de ganhar eleições, 11 de Out., 1953

Uma ditadura libertadora a de Kemal Atartuk, 12 de Out., 1953

Os regimes de absolutismo e a Arte de Furtar, 15 de Out., 1953

Resposta às críticas que lhe foram feitas numa sessão de propaganda da União Nacional, (uma carta de A. S.), 18 de Out., 1953

Resposta às críticas que lhe foram feitas pelo Ministro do Interior, (uma car ca de A. S.), 25 de Out., 1953

Referência à intervenção de Sérgio na $\mathrm{l}^{\circ}{ }^{\circ}$ sessão da oposição no Liceu Camões, 27 de Out., 1953

Resposta ao comunicado da Comissão Distrital da União Nacional do Porto, (contra a acusação que lhe fizeram de plágio), 2 de Nov., 1953

Resposta a um apelo e a uma pergunta de Sua Excelência o Ministro do Interior, (porque não elogia Sérgio o Estado Novo?), 3 de Nov., 1953

Entrevista de Sérgio sobre a apresentação do programa submetido ̀̀ discussão por um grupo de oposicionistas», 5 de Nov., 1953

Como presidente da Comissão Eleitoral de Voto faz as 1.05 declarações acerca do acto eleitoral, 10 de Nov., 1953

Pela revolução contínua do curto-circuito, 14 de Nov., 1953

Cartas do Terceiro Homem, XVI, 21 de Dez., 1953

(Continuação: XVII -15 de Jan, 1954; XVIII -27 de Jan.; XIX - 6 de Fev.; XX - 16 de Fev.; XXI -3 de Mar.; XXII 11 de Mar.; XXIII - 15 de Mar.; XXIV - 18 de Mar.; XXV 27 de Mar.; XXVI - 1 de Abr.; XXVII - 3 de Abr.; XXVIII 5 de Abr.; XXIX - 10 de Abr.; XXX - 16 de Abr.; XXXI 10 de Maio; XXXII — 25 de Jun.; XXXIII — 4 de Dez.)

$\mathrm{O}$ primeiro $e \mathrm{o} 2 .^{\circ}$ lema a propósito de liberdade, igualdade e fraternidade, 4 de Out, 1954

Liberdade, Igualdade, Ordem. Despotismo e Oligarquia segundo a doutrina de Garrett, 9 de Dez, 1954

Novas Cartas do $3 .^{\circ} \mathrm{Homem}$. Sobre a necessidade de criar uma estrutura cooperativa na economia portuguesa, 27 de Maio, 1955 (Continuação: 8 de Jun.; 15 de Jun.; 21 de Jun.; 29 de Jun.; 11 de Jul.; 19 de Jul.; 20 de Jul.; 7 de Ag.; 9 de Fev, 1956; 7 de Mar.; 28 de Mar. (Em torno das discussôes partidárias e historicistas); 6 de Abril.; 12 de Abr.; 10 de Maio; 16 de Jul.; 20 de Jul.; 24 de Jul.; 1 de Ag.; 6 de Ag. (Cartas do Terceiro Homem 
e dois contendores ordeiristas) ; 20 de Out.; 22 de Out.; 24 de Out.; 26 de Out.; 27 de Dez. 1957; 4 de Fev., 1958; 20 de Fev.; 8 de Mar.; 19 de Mar.)

Palavras de António Sérgio na homenagem de Julião Quintinha na Sociedade de Belas Artes, 15 de Jun., 1956

Uma representação ao Sr. Presidente da República assinada por 50

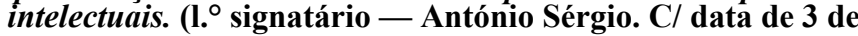
Jul., 1956) 11 de Jul., 1956

O dr. António Sérgio responde ao Diário da Manhã, 30 de Jul., 1956

Tornar efectivos os direitos políticos do art. ${ }^{\circ} 8{ }^{\circ}$ da Constituição - Cumprir os princípios da $\mathrm{ONU}$ - Fazer eleições honestas e criar um Conselho de Estudos Económicos-Sociais, são alguns dos aspectos da Reforma preconizada pelo ilustre pedagogista dr. António Sérgio antigo ministro da Instrução, numa entrevista concedida à República, 30 de Jul., 1956

Entusiasmo e espírito crítico, 5 de Out., 1956

Esclarecimento público (5.11.1956), 17 de Nov., 1956

Inquérito da República sobre as eleições. Peço a todos que saiam da inércia, que se recenseiem sem demora e se preparem para ir às urnas - diz António Sérgio, 25 de Fev., 1957

A criança e o adolescente. Os direitos fundamentais da criança (Responde António Sérgio, 11 de Jun., 1957

O momento político. A legislação que existe e o que nos disse António Sérgio, 9 de Out., 1957

Liberdade do povo e governo do povo pelo povo, 4 de Out., 1957

Reclamo uma coisa, somente uma: o cumprimento não sofismado do art. ${ }^{\circ} 8 .^{\circ}$ da Constituição, (errata do art. a 25 de Out.), 24 de Out., 1957

Recordando José Domingos dos Santos, 30 de Ag., 1958

Educação social e económica do povo que possibilite o governo do povo pelo povo, 4 de Out., 1958

Sobre uma doutrina socialista, 20 de Nov., 1958

Resposta de Sérgio ao inquérito efectuado pela República: Quais as características fundamentais do século actual até aos nossos dias?, 24 de Dez., 1958

Carta de Sérgio à redaç̧ão da República a propósito de um artigo saído num magazine brasileiro, 25 de Abr., 1959, (resposta de A. S. transcrita na revista Manchete)

Dez erros capitais da tirania fascista em Portugal, 31 de Maio, 1974

REVISTA AMERICANA - Local de publicação: Rio de Janeiro

Da natureza da afeção. Ensaios de Psicologia e Pedagogia, n. ${ }^{\circ}$, ano IV, 1913

REVISTA DE EDUCAÇÃO GERAL E TÉCNICA - Boletim da Sociedade de Esiudos Pedagógicos. Direç̧ão: Prof. Almeida Lima, Pedro José da Cunha e Prof. Celestino da Costa. Duração: 1911-1935. Lisboa

Comissão de Inquérito aos trabalhos manuais, n. 2 (série VIII) Dez. 1921, 53-56 pp.

A função da escola primária em Portugal, n. 1 (série IX) Dez. 1927, 97-100 pp. 


\section{REVISTA DE GUIMARÃES}

Divagações Conjecturais sobre o Antigo Pastor Montanhês do Noroeste da Ibéria, vol. $68,1958,{ }^{\circ}{ }^{\circ} 1-2$

REVISTA DO PORTO - Publicação Quinzenal de Arte e Cultura. Director: Carlos Bastos. Duração: de 30 de Out. de 1940 a 20 de Dez. de 1940. Números publicados: 4. Local de publicação: Porto

Diálogo de

Diálogo de

Diálogo de

mortos,n. ${ }^{\circ} 1,30$ de Out. de 1940, 5-7 pp.

Diálogo de mortos, n. ${ }^{\circ}$, 15 de Nov. 1940, 17-19 pp. mortos, ${ }^{\circ}{ }^{\circ}, 30$ de Nov. $1940,31-32$ pp.

REVISTA DE PORTUGAL - Director: Vitorino Nemésio. Duração: de Out. de 1937 a Nov. de 1940. Números publicados: 10. Local de publicação: Coimbra

Tese e antítese nos sonetos de Antero, n. ${ }^{\circ}$, Out. de 1937, 16-32 pp.

REVISTA PORTUGUESA - Edição da Câmara portuguesa de Comércio e do Club Português. Director: dr. Ricardo Severo. Local de publicação: S. Paulo, Brasil

Para a reforma democrática da Sociedade das Nações, fase. I (tomo I), 1930, 45-48 pp.

Portugal Colonial e Portugal Metropolitano, fase. II (tomo I), 1930, 136-138 pp.

REVUE BLEU - Revue Politique et Littéraire - Paris

Apres la révolution portugaise, n. ${ }^{\circ}$ 15, 6 Août 1927, 449-451 pp.

\section{REVUE DE GENÈVE}

Portugal - (La littérature portugaise d'aujourd'hui), Ag. 1925, 990-1002 pp.

LA REVUE MONDIALE - Ancienne «Revue des Revues». Encyclopédie de quinzaine - Paris

La S. D. N. et la Dictature Portugaise, n. 7 (vol. CLXXXII), l.er Avril 1928, 233-236 pp.

Le Brésil et le Portugal devant la S. D. N. et le dessous de la dictature portugaise..., n. ${ }^{\circ}$ 18, (vol. CLXXXIV), 15 Septembre 1928, 113-118 pp.

SEARA NOVA - Revista de Doutrina e Crítica. $1 .^{\circ}$ número: 15 de Out. de 1921. Local de publicação: Lisboa 
O problema da instrução religiosa nas escolas particulares, $\mathbf{n} .^{\circ} 21$, Fev.-Mar. de 1923, 148-150 pp.

A União Cívica, os seus intuitos e os seus métodos, n. ${ }^{\circ} 22$, Abr. de 1923, 157-161 pp.

O sr. Afonso Costa sente-se português no estrangeiro, $n .^{\circ} 22$, Abr. de 1923,165 p.

O sr. Brito Camacho sente-se estrangeiro em Portugal, n. ${ }^{\circ} 22$, Abr. de $1923,166 \mathrm{p}$.

Recorre-se ao sobrenatural e consulta-se a mesa de pé de galo; aparece a República-que-eles-sonharam, n. ${ }^{\circ} 22$, Abr. de 1923, 166$-167 \mathrm{pp}$.

Ura diletante, adorador abstracto da competência que desdenha dos competentes, $\mathrm{n} .^{\circ} 22$, Abr. de 1923, 167-168 pp .

BIBLIOGRAFIA:

Ricardo Jorge: $O$ óbito de D. João II, n. ${ }^{\circ}$ 22, Abr. de 1923, 173 p.

A. Lopes Vieira: $O$ romance de Amadis e Da reintegração dos Primitivos Portugueses, n. ${ }^{\circ} 2$, Abr. de 1923, 173-174 pp.

A política de Oliveira Martins,.$^{\circ}$ 23, Maio de 1923, 177-182 pp.

Junta de educação; Teatro regional e $\mathrm{O}$ desacato ao $\mathrm{Sr}$. Arcebispo de Évora, n. ${ }^{\circ}$ 23, Maio de 1923, 192 p.

BIBLIOGRAFIA:

Nação Portuguesa, n. ${ }^{\circ}$ 23, Maio de 1923, 193-196 pp.

Não está certo, $n .^{\circ} 24$, Jun. de 1923,209 p.

O Sr. Bernardino Machado e a União Cívica, n..$^{\circ} 24$, Jun. de 1923, 209-211 pp.

Colonização do Alentejo, n. ${ }^{\circ}$ 24, Jun. de 1923, 211 p.

Traidores à pátria, n. ${ }^{\circ}$ 24, Jun. de 1923, 211-212 pp.

BIBLIOGRAFIA:

Revista Portuguesa, n. ${ }^{\circ}$ 4, Jun. de 1923, 216 p.

Primeiro Livro de Zoologia, por H. Parreira e F. Cabral, n. ${ }^{\circ} 24$, Jun. de 1923, 218-219 pp.

Álvaro Pires de Évora, por Reinaldo dos Santos, n. ${ }^{\circ} 24$, Jun. de 1923, 218-219 pp.

Congresso agrícola de Viseu, $n .^{\circ} 25$. Jul. de 1923, 18 p.

Reforma da educação, n. ${ }^{\circ} 25$, Jul. de 1923,19 p.

Brincadeira de mau gosto, n. ${ }^{\circ} 25$, Jul. de 1923, 19 p.

Eça de Queiroz e a sociedade portuguesa (a propósito de um prefácio de Agostinho de Campos), n. ${ }^{\circ}$ 26, Ag.-Set. 1923, 39-42 pp.

Relações com a França; ensino livre, ensino obrigatório?; O parlamento, n. ${ }^{\circ}$ 26, Ag.-Set. 1923, 42 p.

O caso de Espanha, n. ${ }^{\circ}$ 27, Out.-Nov. 1923, 64-65 pp.

Irrigação da região de Moura, n. ${ }^{\circ}$ 27, Out.-Nov. 1923, 65 p.

1924

Ideas educativas de um candidato trabalhista. "A Chama Imortal", de Wells, n. ${ }^{\circ} 31,15$ de Fev. 1924, 134-140 pp.

As juntas de freguesia e a carestia de vida, n. ${ }^{\circ}$ 32, 1 de Mar. 1924, $162 \mathrm{p}$. 
Coisas do Demo no papel do Nemo, n. ${ }^{\circ} 33,20$ de Mar. 1924, 178-180 pp.

No governo (relatório que $A$. S. apresentou ao seu sucessor ao entregar-lhe a pasta da Instrução Pública), n. $.^{\circ} 34,9$ de Abr. 1924, 195-197 pp.

Um programa, n. ${ }^{\circ}$ 35, 15 de Maio 1924, 226 p.

Instruçã̃o, n. ${ }^{\circ}$ 35, 15 de Maio 1924, 226 p.

Coleç̧ão assíria, n. ${ }^{\circ}$ 36, Jun. 1924, 242 p.

Nação e governantes, n. ${ }^{\circ}$ 36, Jun. 1924, 242 p.

O que se chama uma questão "literária»... em Portugal. Explicações aos meus leitores sobre as afirmações de um artigo do sr. Fidelino de Figueiredo, n. ${ }^{\circ}$ 37, Jul.-Ag. 1924, 7-9 pp.

Escolas primárias superiores, n. ${ }^{\circ} 37$, Jul.-Ag. 1924, 10 p.

Palavras de António Maura, n. ${ }^{\circ}$ 37, Jul.-Ag. 1924, 10 p.

Problemas pedagógicos, n. ${ }^{\circ} 38$, Set.-Out. 1924, 25 p.

Um opúsculo político, n. ${ }^{\circ} 38$, Set.-Out. 1924, 36 p.

O sindicalismo $e$ o movimento das "Forças Vivas", n. ${ }^{\circ} 38$, Set.-Out. 1924, 38 p.

O programa do governo e o da Seara Nova, n. ${ }^{\circ}$ 39, Nov.-Dez. 1924, 44 p.

Paixão clerical e paixão anti-clerical, n. ${ }^{\circ}$ 40, Jan. 1924, 72 p.

1925

A União Agrária, n. ${ }^{\circ}$ 41, 1 de Fev. 1925, 84 p.

Carta aberta a Trindade Coelho, ${ }^{\circ}{ }^{\circ}$ 42, 15 de Fev. 1925, 109-110 pp.

Questão de estética literária, n. ${ }^{\circ} 42,15$ de Fev. 1925, 115 p.

Tréplica a Carlos Malheiro Dias sobre a questâo do Desejado, n. ${ }^{\circ} 43$, 15 de Mar. 1925, 123-130 pp.

Um exemplo, n. ${ }^{\circ} 43,15$ de Mar. 1925,130 p.

Melros, $n .^{\circ} 43,15$ de Mar. 1925, 135 p.

Tréplica a Carlos Malheiro Dias sobre a questão do Desejado, n. ${ }^{\circ} 44$, Abr. 1925, 153-158 pp.

Tréplica a Carlos Malheiro Dias sobre a questão do Desejado, n. ${ }^{\circ}$ 45-46, Maio 1925, 173-177 pp.

Carta aberta a um conservador lusitano, $n .^{\circ} 45-46$, Maio 1925, 180 $-181 \mathrm{pp}$.

Nota (sobre um artigo de Francisco Aragão), n. ${ }^{\circ}$ 47. Jun. 1925, 202 p.

Soberania do povo, n. ${ }^{\circ}$ 47, Jun. 1925, 202 p.

Burocracias, n. ${ }^{\circ}$ 47, Jun. 1925, 202 p.

Explicações ao Ex.mo Sr. Prof. Martinho Nobre de Melo sobre as doutrinas morais dos meus «Ensaios», n. ${ }^{\circ}$ 49, 15 de Jul. 1925, 6-10 pp.

O calor da máscara, ${ }^{\circ}{ }^{49}, 15$ de Jul. 1925, 4 p.

Voltairianismo de pechisbeque, n. ${ }^{\circ} 49,15$ de Jul. 1925, 4 p.

Vida literária, n. ${ }^{\circ} 49,15$ de Jul. 1925, 15 p.

Explicação ao Ex. ${ }^{m o}$ Sr. Prof. Martinho Nobre de Melo sobre as doutrinas morais dos meus «Ensaios». (Conclusão), n. ${ }^{\circ}$ 50, 1 de Ag. 1925, 35-38 p.

Sobre o problema da instrução pública, n. ${ }^{\circ} 51,15$ de Ag. $1925,50 \mathrm{p}$.

De Pacheco e da crítica, $n .^{\circ}$ 53, 15 de Set. 1925, 89-90 pp.

O problema da cultura em Portugal e o significado do Seiscentismo na sua história, n. $^{\circ}$ 56, 17 de Out. 1925, 148-151 pn.

Institutos de investigação científica, $\mathrm{n} .{ }^{\circ} 56,17$ de Out. 1925, $151 \mathrm{p}$.

As colónias portuguesas perante a Sociedade das Nações, n. ${ }^{\circ}$ 56, 17 de Out. 1925, 157 pp.

Sobre o julgamento de 18 de Abril, n. ${ }^{\circ}$ 57, 24 de Out. 1925, 168 p.

O problema da cultura em Portugal e o significado do Seiscentismo na sua história. (Conclusão), n. ${ }^{\circ}$ 57, 24 de Out. 1925, 169-171 pp. 
Um manifesto eleitoral, $\mathrm{n} .^{\circ}$ 57, 24 de Out. 1925, 164 p.

Sociedade das Nações, n. ${ }^{\circ}$ 57, 24 de Out. 1925, 173 p.

Um jornal, n. ${ }^{\circ} 58,31$ de Out. 1925, 198 p.

Virá outra igual?, n. ${ }^{\circ}$ 59, 7 de Nov. 1925, 213 p.

Monumento a Antero de Quental, n. ${ }^{\circ}$ 59, 7 de Nov. 1925, 215 p.

Secção oriental da Seara Nova, n. ${ }^{\circ}$ 59, 7 de Nov. 1925, 217 p.

Os dois critérios, $\mathrm{n} .^{\circ} 65,19$ de Dez. $1925,88 \mathrm{p}$.

O presépio, n. ${ }^{\circ}$ 66, 22 de Dez. 1925, 104 p.

1926

Liga Propulsora da Instrução Pública em Portugal, n. ${ }^{\circ}$ 67, 2 de Jan. 1926, 129-130 pp.

O duelo, n. ${ }^{\circ}$ 67, 2 de Jan. 1926, 134 p.

Ocidente e Oriente, n. ${ }^{\circ} 67,2$ de Jan. 1926, 135-136 pp.

Misticismo, n. ${ }^{\circ} 70,16$ de Jan. 1926,189 p.

Agua mole em pedra dura, n. ${ }^{\circ}$ 70, 16 de Jan. 1926, $196 \mathrm{p}$.

Monumentos, n. ${ }^{\circ} 71,23$ de Jan. 1926, 206 p.

Cartas a jovens portugueses, n. ${ }^{\circ} 71,23$ de Jan. 1926, 214-216 pp.

Uma homenagem, $n .^{\circ} 71,23$ de Jan. 1926, 216 p.

Pensões de estudo no estrangeiro, n. ${ }^{\circ}$ 71, 23 de Jan. 1926, 216 p.

Liga Propulsora da Instrução Pública em Portugal, n. ${ }^{\circ}$ 72, 30 de Jan. 1926, 230-231 pp.

Deficit mental, n. ${ }^{\circ} 72,30$ de Jan. 1926, 224 p.

Um bom livro, n. ${ }^{\circ}$, 30 de Jan. 1926, 224 p.

Paradoxo explicado, ${ }^{\circ} 72,30$ de Jan. 1926, 229 p.

Liga europeia para a defesa da liberdade, n. ${ }^{\circ}$, 30 de Jan. 1926, 231 p.

Liga Propulsora para a Instrução em Portugal (prefácio para a tradução das "Lições de Coisas» de Murché, a sair brevemente), n. ${ }^{\circ}$ 74, 13 de Fev. 1926, 35-36 pp.

Lições de civismo, n. ${ }^{\circ}$ 75, 20 de Fev. 1926, $47 \mathrm{p}$.

Duas revistas pedagógicas, n. ${ }^{\circ}$ 75, 20 de Fev. 1926, 53 p.

Cartas leves sobre temas graves. Educadores, pedagogistas e cartiIhistas, n. ${ }^{\circ}$ 76, 27 de Fev. 126, 77-78 pp.

A mentalidade nacional, $\mathrm{n} .^{\circ}$ 79, 20 de Mar. 1926, 129 p.

Ainda a questão dos monumentos, n. 79,20 de Mar. 1926, 133 p.

Política, ideas e palavras, n. ${ }^{\circ}$ 80, 27 de Mar. 1926, 149 p.

O homem público e os cidadãos, n. ${ }^{\circ} 80,27$ de Mar. $1926^{\wedge} 155$ p.

Cartas leves sobre temas graves. A propósito da conferência do prof. Magalhães Colaço, n. ${ }^{\circ}$ 81, 1 de Abr. 1926, 170-173 pp.

Por Coimbra, n. ${ }^{\circ}$ 83, 15 de Abr. 1926, 209 p.

Ainda sobre o problema dos monumentos, n. ${ }^{\circ}$ 83, 15 de Abr. 1926, 209 p.

Os hormones da «Época», n. ${ }^{\circ}$ 85, 29 de Abr. 1926

Explicação sobre os partidos aos partidários da Reconquista, n. ${ }^{\circ} 86$, 6 de Maio 1926, 276 p.

Cartas leves sobre temas graves. Aos jovens Seareiros de Coimbra, sobre a maneira de lidar com os inimigos da Luz e dçi Razão, n. ${ }^{\circ}$ 87, 13 de Maio 1926, 292-294 pp.

Cartas leves sobre temas graves. Aos meus jovens amigos que me pediram que Respondesse Aquilo, n. ${ }^{\circ}$ 88, 20 de Maio 1926, 311-313 pp.

Cartas leves sobre temas graves. A Actual situação política $e$ a instrução pública, n. ${ }^{\circ} 93,23$ de Jun. 1926, 414 p.

Palavras de sinceridade, n. ${ }^{\circ} 93$, de 23 de Jun. de 1926, 418 p.

Observações e ideologia, produtor e cidadão, n..$^{\circ}$ 94, 8 de Jul. de 1926, 428-429 pp. 
Um homem de princípios, n. ${ }^{\circ}$ 95, 15 de Jul. 1926, 444 p.

Dogmatismos, n. ${ }^{\circ} 95,15$ de Jul. 1926, 455 p.

Onde pô-los?, n. ${ }^{\circ} 95,15$ de Jul. 1926, 455 p.

Guarda-sol, n. ${ }^{\circ}$ 96, 12 de Ag. 1926, 474 p.

1927

Uma lição de inteligência, ${ }^{\circ}{ }^{\circ}$ 98, s. d., (1927)

O oriente, o ocidente e a nova civilização ecuménica, n. ${ }^{\circ} 99,12$ de Maio 1927, 46 p.

Carta de agradecimento a D. Basílio, n. ${ }^{\circ} 100,9$ de Jun. 1927, 78-79 pp.

Sobre a inter-cultura de Portugal e Espanha, n. ${ }^{\circ} 102,14$ de Jul. 1927, 177-118 pp.

(Crítica ao livro «Diálogo de Doctrina Cristiana» de Juan Vaidés), n. ${ }^{\circ} 108,20$ de Out. 1927, 237 p.

(Crítica ao livro "Christophe Colombe Catalan" de Luís Ulloa), n. ${ }^{\circ}$ 111, 8 de Dez. 1927, 297 p.

1928

Ao jóvem leitor. (Prefácio do $2 .^{\circ}$ vol. dos «Ensaios» no prelo), n..$^{\circ} 129$, 20 de Set. 1928, 164-165 pp.

Alocução aos Voluntários da Paz, n. ${ }^{\circ} 137,15$ de Nov. 1928, 333-334 pp.

A reforma da instrução primária, n. $^{\circ} 138,22$ de Nov. 1928, 350-351 pp.

O problema da cultura em Portugal, (dos «Ensaios», no prelo), n. ${ }^{\circ} 141$, 13 de Dez. 1928, 401-403 pp.

(Nota bibliográfica: J. Preto Pacheco «D. Sebastião à Margem de uma Polémica», Porto, Imprensa Moderna. 1928), n. ${ }^{\circ} 143,27$ de Dez. 1928, 436-438

1929

Ideal e facto sensível, política e ciência, meios e fins, $n .^{\circ} 144,3$ de Jan. 1929, 443-446 pp.

O clássico na educação e o problema do latim, n. ${ }^{\circ}$ 146, 17 de Jan. 1929, 19-21 pp.

Nótulas de leitura (Camoneana), n. ${ }^{\circ} 150,28$ de Fev. 1929, 94 p.

Método científico, história, política e tradição - I, n. ${ }^{\circ} 151,7$ de Mar. 1929, 99-104 pp.

Sinceríssima resposta à resposta sincera do Sr. Pacheco, n. ${ }^{\circ} 152,14$ de Mar. 1929, 124-126 pp.

Método científico, história, política e tradição - II, n. ${ }^{\circ}$ 153, 21 de Mar. 1929, 134-138 pp.

A educação para a paz, n. ${ }^{\circ} 157,18$ de Abr. 1929, 201-202 pp.

Palavras supérfluas, n. ${ }^{\circ}$ 158, 25 de Abr. 1929, 222-233 pp.

Dois capítulos da "História de Portugal» de A. Sérgio. O descobrimento da índia, $\mathrm{n} .^{\circ}$ 159, 2 de Maio 1929, 227-231 pp.

O jogral de Deus, $n .^{\circ} 160,9$ de Maio 1929, 249-250 pp.

O meu reino não é deste mundo, ${ }^{\circ}{ }^{\circ} 162,23$ de Maio 1929, 280 p.

Idealismo e realismo. "Morale d'abord" $e$ "Politique d'abord», n. ${ }^{\circ} 163$, 30 de Maio 1929, 293-301 pp.

Trechos da "História de Portugal» de A. Sérgio, n. $.^{\circ} 165,13$ de Jun. 1929, 327-328 pp.

Trechos da "História de Portugal» de A. Sérgio, n. ${ }^{\circ}$ 167, 27 de Jun. 1929, 363-364 pp. 
Ora essa: pois não...., n. $.^{\circ} 168,4$ de Jul. 1929, 379-382 pp.

Ora até que enfim!, n. ${ }^{\circ} 170,18$ de Jul. 1929, 19-25 pp.

Despedida, n. ${ }^{\circ} 174,15$ de Ag. 1929, 87-93 pp.

Para matar saudades, n. ${ }^{\circ} 183,17$ de Out. 1929, 227-231 pp.

Para matar saudades. Continuação primeira, n. ${ }^{\circ} 186,7$ de Nov. 1929, 276-281 pp.

Para matar saudades. Continuação primeira, n. ${ }^{\circ}$ 186, 7 de Nov. 1929, 339-345 pp.

1930

Em torno de um livrinho, n. ${ }^{\circ} 201,29$ de Fev. 1930, 140-142 pp.

Portugal colonial $e$ Portugal metropolitano, n. ${ }^{\circ}$ 214, 24 de Jul. 1930, 339-340 pp.

Em torno da crise mental do séc. XVIII (a propósito de um ensaio de Hernâni Cidade), n. ${ }^{\circ}$ 215, 31 de Jul. 1930, 355-359 pp.

Sobre a aplicação política da idea de igualdade, n. $216,7 \mathrm{de}$ Ag. 1930, 371-377 pp.

A Seara Nova e o conceito de revolução (c/ Jaime Cortesão e Raul Proença), n. ${ }^{\circ} 224,30$ de Out. 1930, 115 p.

Sociedade e espírito, acção política e sinceridade intelectual, ${ }^{\circ}{ }^{\circ} \mathbf{2 3 0}$, 25 de Dez. 1930, 211-215 pp.

Sobre uma crise de consciência, n. 231,29 de Dez. 1930, 232-233 pp.

1931

A veracidade, o idealismo e a política, n. ${ }^{\circ}$ 237, 5 de Fev. 1931, 323-329 pp.

A Antigona de António Sérgio e os mocinhos da «Acção» de Coimbra, n. ${ }^{\circ}$ 243, 19 de Mar. 1931, 45-46 pp. (não assinado)

A democracia em Espanha, n. ${ }^{\circ} 248,14$ de Maio 1931, 120-121 pp.

Por Espanha, $n .^{\circ} 258,20$ de Ag. 1931, 280-1 pp. (assinado S.)

Para a anulação racional do déficit económico, n. 274,3 de Dez. 1931, 151-155 pp.

1932

Razão e poesia, razão e mística. (Fragmento de uma nota do $3 .^{\circ}$ vol. dos «Ensaios» no prelo), $.^{\circ} 286,18$ de Fev. 1932, 348-353 pp.

(Nota a um texto de Fabien France), n. ${ }^{\circ} 288,3$ de Mar. 1932,380 p.

Razão e poesia, razão e mística. (Fragmento de uma nota do $3 .^{\circ}$ vol. dos «Ensaios» no prelo) — continuação, n. ${ }^{\circ}$ 289, 10 de Mar. 1932, 5-10 pp.

Nota a um texto de Fabien France, n. ${ }^{\circ}$ 289, 10 de Mar. 1932, 12 p.

Sobre a reforma do legislativo (de A Aguia de Jan.-Fev. 1932), n. ${ }^{\circ}$ 293, 7 de Abr. 1932, 76-78 pp.

(Nota a um texto de Fernand Corços), n. ${ }^{\circ} 294,14$ de Abril 1932, 90 p.

Tentando desfazer equívocos. Resposta sincera $e$ amiga ao sr. João Gaspar Simões, n. ${ }^{\circ}$ 296, 28 de Abr. 1932

(Nota ao artigo O sindicato e o Estado), n. ${ }^{\circ} 297,5$ de Maio 1932, 140 p.

(Nota ao artigo Consideraçóes soltas sobre cooperativismo), n. ${ }^{\circ} 299$, 19 de Maio 1932, 168 p.

Um inquérito (resposta a um inquérito aberto pelo Diário da Noite), n. ${ }^{\circ} 300,26$ de Maio, 178, 190-191 pp. (as perguntas a este inquérito constam do Diário da Noite de 3-2-1932)

Mais uma facada e, por consequência, mais um feliz pretexto para me explicar, $\mathrm{n} .^{\circ} 300,26$ de Maio 1932, 182-184 pp. 
(Várias notas ao artigo de Ernest Poisson intitulado $A$ produção governada pelo consumo como verdadeira realização do ideal socialista), n. ${ }^{\circ} 302,9$ de Jun. 1932, 216-217 pp.

(Notas a um texto de Charles Gide), n. ${ }^{\circ} 303,16$ de Jun. 1932, 234$-235 \mathrm{pp}$.

Ainda e sempre o pessoalismo, n. ${ }^{\circ}$ 304, 23 de Jun. 1932, 243-246 pp.

$A$ república e a religião, $\mathrm{n} .^{\circ} 305,30$ de Jun. $1932,259-260$ pp.

Historicismo arquivístico, miragem retórica e problemática intelectual, n. ${ }^{\circ}$ 310, 4 de Ag. 1932, 339-345 pp.

Refutação resignada e serena de uma caluniosa acusação de má fé, n. ${ }^{\circ}$ 311, 11 de Ag. 1932, 355-363 pp.

Nota a um texto de Ernest Poisson: $A$ intervenção dos teóricos contabilistas e financeiros no funcionamento das sociedades cooperativas, $\mathrm{n}^{\circ}$ 312, 18 de Ag. 1932, $382 \mathrm{p}$.

(Nota ao artigo de Ernest Poisson Democracia de consumidores e democracia de produtores), ${ }^{\circ} 313,25$ de Ag. 1932, 8 p.

(Nota a um texto de Carlos Gide), n. ${ }^{\circ} 314,1$ de Set. 1932, 24 p.

(Nota de bibliografia), $n .^{\circ} 314,1$ de Set. 1932, 24 p.

(Nota a uma passagem de Le Programme Coopératiste de Charles Gide), n. ${ }^{\circ} 320,13$ de Out. 1932,123 p.

(Nota a uma passagem de Le Programme Coopératiste de Charles Gide), . $^{\circ} 321,20$ de Out. 1932,143 p.

(Nota a uma passagem de Le Programme Coopératiste de Charles Gide), n. ${ }^{\circ} 322,27$ de Out. 1932, 156 p.

O programa, a organização e a acção como fontes permanentes de concórdia, n. ${ }^{\circ} 323,3$ de Nov. 1932, 166-167 pp.

(Nota a uma passagem de Le Programme Coopératiste de Charles Gide), $n .^{\circ} 324,15$ de Dez. 1932, 187 p.

1933

Retalhos de doutrina democrática, n. ${ }^{\circ}$ 327, 12 de Jan. 1933, 230-233 pp.

Nota crítica ao livro do Prof. A. Ferreira de Macedo - Os programas $e$ o ensino das matemáticas no liceu, n. ${ }^{\circ} 327,12$ de Jan. 1933, $329 \mathrm{p}$.

Mais retalhos, $\mathrm{n}^{\circ}$ 332, 2 de Mar. 1933, 310-312 pp. (Este artigo e os Retalhos de doutrina democrática de 12.1.1933 estão na base dos Diálogos de Doutrina Democrática)

Cousas, n. ${ }^{\circ 333,9}$ de Mar. 1933, 325 p.

$A$ idea, n. ${ }^{\circ} 335,23$ de Mar. 1933, 363 p.

Notas à traducão de um artigo de J. M. Ludlow sobre O socialismo e cristianismo, $\mathrm{n} .{ }^{\circ} 335,23$ de Mar. $1933,366 \mathrm{p}$.

Grupo Renovação Democrática, $n .^{\circ} 336,30$ de Mar. 1933, 371-373 pp.

Um exemplo: o novo porto de pesca de Lorient-Kéromen, ${ }^{\circ}{ }^{\circ} 336$, 30 de Mar. 1933, 381-382 pp.

Nota ao livro: Sobre a Falsa solução do estatismo comunista, de Harold Laski, n. ${ }^{\circ} 338,13$ de Abr. 1933, 29 p.

Para a reforma democrática da Sociedade das Nações, $n .{ }^{\circ} 339,20$ de Abr. 1933, 35-37 pp.

Diálogo de um democrata e de um estadista burguês, $n .^{\circ} 340,27$ de Abr. 1933, 51-55 pp. (Corresponde ao Diálogo $V$ dos Diálogos de Doutrina Democrática)

Notas a um texto de Carlos Gide: «Cooperativismo agrícola», n. ${ }^{\circ} 340$, 27 de Abr. 1933, 61-62 pp.

Sobre o filologismo (não assinado), n. ${ }^{\circ} 341,4$ de Maio 1933, 77 p.

(Pequenas notas sobre Antero de Quental), n. ${ }^{\circ} 342,11$ de Maio 1933, 93-94 pp. 
Questão prévia de um ignorante aos prefaciadores da lírica de Camões, n. ${ }^{\circ} 343,18$ de Maio 1933, 99-115 pp.

Declaração, n. ${ }^{\circ} 34,25$ de Maio 1933, 119 p.

Cooperativa e parlamento, ${ }^{\wedge} \mathrm{n}{ }^{\circ} 344,25$ de Maio 1933, 126-127 pp.

Um mau inimigo de si próprio e bom inimigo da Seara Nova, n. ${ }^{\circ} 345$, 1 de Jun. 1933 (não assinado)

(Notas a um passo antológico de Antero), n. ${ }^{\circ} 346,8$ de Jun. 1933, 157-159 pp.

Tradução e nota a uma passagem do livro The Theory of Political Economy de Stanley Jevons, n. ${ }^{\circ}$ 347, 15 de Jun. 1933, 173-174 pp.

Vale de Josefat (nota sobre este volume de Memórias de Raul Brandão, não assinado), ${ }^{\circ}{ }^{\circ}$ 348, 22 de Jun. 1933, 180-193 pp.

Nota a $O$ Programa Cooperativo de Carlos Gide, n. ${ }^{\circ} 349,29$ de Jul. 1933, 206 p.

Nota a O Programa Cooperativo II de Carlos Gide, $n .^{\circ} 351,17 \mathrm{de}$ Ag. 1933,239 p.

(Notas a um trecho de B. Lavergne Les Régies Coopératives), n. ${ }^{\circ} 352$, 24 de Ag. 1933, 253-257 pp.

A propósito dos dizeres de um jornalista, n. ${ }^{\circ} 353,31$ de Ag. 1933, 260-272 pp. (não assinado)

Uma opinião sobre o falso Corporativismo à fascista, $n .^{\circ} 357,28 \mathrm{de}$ Set. 1933, 324-336 (não assinado)

Nótulas soltas, n. ${ }^{\circ} 357,28$ de Set. 1933, 3 p.

Livros e periódicos (não assinado e identificado por $\mathrm{V}$. Magalhães Vilhena), n. ${ }^{\circ} 35,5$ de Out. 1933, 351-352 pp.

Esclarecimento a um tradicionalista sobre a corporação sebenteira de Coimbra, (não assinadoy, n. ${ }^{\circ} 359,12$ de Out. 1933, 356-369 pp.

Sobre a política de Camões, n. ${ }^{\circ} 359,12$ de Out. 1933, 359-365 pp.

Sobre o socialismo de Antero, $\mathrm{n} .^{\circ}$ 362, 2 de Nov. 1933, 24-27 pp.

Sobre Antero (nota bibliográfica não assinada e identificada por $\mathrm{V}$. Magalhães Vilhena), n. ${ }^{\circ} 365,23$ de Nov. 1933, 65 p.

Aclarando (sobre a acusação de monarquismo, não assinado), n. ${ }^{\circ} 366$, 30 de Nov. 1933, 82-93 pp.

Ainda a propósito das eleições em Espanha, n. ${ }^{\circ}$ 366, 30 de Nov. 1933, 93-94 pp.

\section{4}

Notícia crítica sobre o livro de Casais Monteiro, Considerações Pessoais, n. ${ }^{\circ} 370,4$ de Jan. 1934, 154-159 pp.

Breve aditamento do não-percebe-nada. (Carta a Casais Monteiro)

N. ${ }^{\circ} 2$, n. $^{\circ} 373,25$ de Jan. 1934, 199-200 pp.

Cartas despretenciosas a um anti-intelectualista bergsoniano-Carta I, n. ${ }^{\circ}$ 375, 8 de Fev. 1934, 227-229 pp.

Cartas despretenciosas a um anti-intelectualista bergsoniano - Carta II, n. ${ }^{\circ}$ 376, 15 de Fev. 1934, 243-245 pp.

Cartas despretenciosas a um anti-intelectualista bergsoniano - Carta III, n. ${ }^{\circ} 377,22$ de Fev. 1934, 259-261 pp.

Cartas despretenciosas a um anti-intelectualista bergsoniano - Carta $I V$, n. ${ }^{\circ} 378,1$ de Mar. 1934, 275-278 pp.

Cartas despretenciosas a um anti-intelectualista bergsoniano-Carta $V$, n. ${ }^{\circ} 380,15$ de Mar. 1934, 310-313 pp.

Cartas despretenciosas a um anti-intelectualista bergsoniano - Carta VI, n. ${ }^{\circ}$ 381, 22 de Mar. 1934, 328-333 pp.

Cartas despretenciosas a um anti-intelectualista bergsoniano - Carta VII, n. ${ }^{\circ} 382,29$ de Mar. 1934, 348-351 pp. 
Sobre o ensino da filosofia nos liceus. (Proposta apresentada à Sociedade de Estudos Pedagógicos), n. ${ }^{\circ}$ 385, 19 de Abr. 1934, 13 p.

A propósito dos Quatro de Espanha - I, n. $.^{\circ} 391,31$ de Maio 1934, 103-106 pp.

A propósito dos Quatro de Espanha - II, n. ${ }^{\circ} 392,7$ de Jun. 1934, 120-122 pp.

$O$ Bacamarte e a Persuasão (resposta a Tomás Ribeiro Colaço, não assinada), ${ }^{\circ}{ }^{\circ} 393,14$ de Jun. 1934, 142-143 pp.

Prólogo ao artigo de Castelo Branco Chaves sobre Raul Brandão, n. ${ }^{\circ}$ 394, 21 de Jun. 1934, 147 p.

Questões de ensino. Escolas de ensaio e bibliografia pedagógica, n. ${ }^{\circ} 396$, 5 de Jul. 1934, 183-185 pp.

Nota a $O$ cooperativismo agrícola no Egipto de J. Rashad, n. ${ }^{\circ} 397$, 12 de Jul. 1934, 205 p.

Sobre a alta fortuna de uma laracha, n. ${ }^{\circ}$ 398, 19 de Jul. 1934, 218 p.

Notas sobre a actividade estética (sob o pseudónimo de Alvaro de Clari vai), n. ${ }^{\circ}$ 399, 26 de Jul. 1934, 230-232 pp.

Democracia crítica, experimental e cooperativa. (Matéria de 3 artigos publicados no Diário Liberal), n. ${ }^{\circ} 401,9$ de Ag. 1934, 259-263 pp.

Notas sobre a actividade estética (sob o pseudónimo de Álvaro de Clarival), n. ${ }^{\circ}$ 401, 9 de Ag. 1934, 267-268 pp.

Notas sobre a actividade estética (sob o pseudónimo de Álvaro de Clarival), n. ${ }^{\circ}$ 404, 30 de Ag. 1934, 314-317 pp.

Em torno da Ilusão Revolucionária de Antero, n. 406-408, 11 de Set. 1934, 366-376 pp.

Esclarecimentos $e$ interrogações de um idealista $-I, n .^{\circ} 410,11$ de Out. 1934, 19-23 pp.

Explicações de um amador de ideas que não ambiciona ser importante, n. ${ }^{\circ}$ 410, 11 de Out. 1934, 28-29 pp.

Esclarecimentos e interrogações de um idealista $-I I,{ }^{\circ} 411,18$ de Out. 1934, 35-40 pp.

Uma explicação, n. ${ }^{\circ} 412,25$ de Out. 1934, 59 p.

Programas dogmatizantes - I, n. ${ }^{\circ} 416,22$ de Nov. 1934, 119-123 pp.

Programas dogmatizantes - II, n. ${ }^{\circ} 417,29$ de Nov. 1934, 135-138 pp.

Programas dogmatizantes - III, n. ${ }^{\circ} 419,13$ de Dez. 1934, 166-169 pp.

Um debate, n. ${ }^{\circ}$ 419, 13 de Dez. 1934, 170 p.

1935

Programas dogmatizantes - IV, n. ${ }^{\circ} 422,3$ de Jan. 1934, 211-214 pp. *

Nota (a um artigo de José Marinho), n. ${ }^{\circ}$ 423, 10 de Jan. 1934, 229-230 pp.

Nota da redacção (à resposta a um inquérito respondido por Fernando Lopes Graça), n. ${ }^{\circ}$ 423, 10 de Jan. 1934, 236 p.

Programas dogmatizantes $-V$, n. ${ }^{\circ}$ 424, 17 de Jan. 1934, 243-248 pp.

1935

Programas dogmatizantes - VI. Conclusão: sugestões para a organização de um programa racional de Ciências da Natureza, n. ${ }^{\circ} 426$, 14 de Fev. 1935, 280-284 pp.

Programas dogmatizantes - VII. Prosseguimento da conclusão: sugestões para a organização de um programa racional de Ciências da Natureza, n. ${ }^{\circ}$ 427, 21 de Fev. 1935, 293-297 pp.

\footnotetext{
* A notação do ano 1934 surge por gralha da revista
} 
(Notícia crítica acerca de um estudo de L. Araquistain sobre Ortega Y Gasset), não assinado, e identificado por V. Magalhães Vilhena, n. ${ }^{\circ}$ 430, 14 de Mar. 1935, 347 p.

Da função da ironia no diálogo de ideas, n. ${ }^{\circ} 431,21$ de Mar. 1935, $362-366 \mathrm{pp}$.

A propósito de uma resposta a um inquérito, n. ${ }^{\circ}$ 434, 11 de Abr. 1935, 18 p. (do Diário de Lisboa)

Em torno da teoria bergsoniana sobre o instinto $e$ sobre as suas relações com a inteligência - I, n. ${ }^{\circ}$ 434, 11 de Abr. 1935, 19-24 pp.

A Seara Nova e a Acçấo Política (não assinado e identificado por $V$. Magalhães Vilhena), $n .^{\circ}$ 435-436, 16 de Maio 1935, 55-56 pp.

Rectas-Pronúncias (sobre o purismo da lingua e os neologismos, não assinado), n. ${ }^{\circ}$ 435-6, 16 de Maio 1935, 53-55 pp.

Em torno da teoria bergsoniana sobre o instinto $e$ sobre as suas relações com a inteligência - II, $n .^{\circ} 437,30$ de Maio 1935, 70-75 pp.

Ainda a propósito de uma resposta a um inquérito, $n .^{\circ} 437,30$ de Maio 1935, 66 p.

Rápidas explicações a propósito de um relatório, n. ${ }^{\circ} 439,13$ de Jun. 1935, 99-104 pp.

Nótulas. Crítica de papel-de-tornesol, n. ${ }^{\circ} 442,4$ de Jul. 1935, 150-152 pp.

$A$ "Renascença Portuguesa" como corrente doutrinal e como organização editora, n. ${ }^{\circ} 443,11$ de Jul. 1935, 162-164 pp.

Romantismo e equilíbrio (não assinado e identificado por $V$. Magalhães Vilhena), $n .^{\circ} 459,5$ de Dez. 1935, 34-46 pp.

1936

Resposta a uma consulta - I, n. ${ }^{466,20}$ de Fev. 1936, 153-156 pp.

Canções de bordo (conferência realizada num concerto da Universidade Popular Portuguesa), $n .^{\circ}$ 468, 5 de Mar. 1936, 183-188 pp.

Fragmento de um diálogo, n. ${ }^{\circ} 476,4$ de Jun. 1936, 307-314 pp.

Calendário seareiro (não assinado), n. ${ }^{\circ} 477,11$ de Jun. 1936, 322-334 pp.

Carta a Hernani Cidade, n. ${ }^{\circ}$ 478, 18 de Jun. 1936, 339-345 pp.

Sobre os inconvenientes de se desprezar a clareza do entendimento, n. ${ }^{\circ}$ 482, 13 de Ag. 1936, 18-31 pp. (critica a Sant'Anna Dionisio)

(Notas apostas a um trecho do P.e António Vieira), n. ${ }^{\circ} 487,17$ de Out. 1936, 108-110 pp.

Cronistas retóricos e testemunhas verídicas, (de um artigo de $A$. S. publicado num jornal da província), n. ${ }^{\circ} 488,24$ de Out. 1936, $125 \mathrm{p}$.

Explicações sobre «Os dois Anteros», n. ${ }^{\circ}$ 488, 24 de Out. 1936, 115-118 pp.

(Notas apostas a um sermão do P.e António Vieira), n. ${ }^{\circ} 489,29$ de Out. 1936, 135-139 pp.

1937

Em torno dos barroquismos musicais e de música espanhola dos sécs. XVI e XVII (palestrazinha introdutória a um concerto) $-I$, n. ${ }^{\circ}$ 498, 18 de Fev. 1937, 279-282 pp.

Em torno dos barroquismos musicais e de música espanhola dos sécs. XVI e XVII (palestrazinha introdutória a um concerto) - II, n. ${ }^{\circ}$ 499, 25 de Fev. 1937, 299-301 pp.

O humanismo da «Seara Nova», n. ${ }^{\circ}$ 500-503, 1 de Abr. 1937, 342-343 pp.

Factos $e$ documentos (transcrição de uma entrevista dada ao Primeiro de Janeiro), n. $^{\circ}$ 500-503, 1 de Abr. 1937, 372-373 pp.

(Nota que acompanha a primeira colaboração de Abel Salazar na «Seara Nova»), n. ${ }^{\circ}$ 505, 15 de Abr. 1937, 3 p. 
Um problema de estética, n. ${ }^{\circ}$ 507, 29 de Abr. 1937, 42-55 pp.

Religião, clericalismo, anti-clericalismo e reformas sociais, n. ${ }^{\circ} 508,6$ de Maio 1937, 62 p.

Em torno da expressã̃o «civilização cristã,» n. ${ }^{\circ}$ 509, 13 de Maio 1937, 83-85 pp.

Pequeninos pontos que o acaso vai trazendo, e que submeto à meditação de jovens amigos que planeiam uma obra de vulgarização, n. ${ }^{\circ}$ 510, 20 de Maio 1937, 103-107 pp.

Dr. Afonso Costa, n. ${ }^{\circ}$ 510, 20 de Maio 1937, 118 p.

Ainda o problema da vulgarização, $n .^{\circ}$ 511, 27 de Maio, 1937, 122$-138 \mathrm{pp}$.

A propósito de discussões sobre um artigo, n. ${ }^{\circ}$ 511, 27 de Maio 1937, 124-125 pp.

Ideas de um mundo extinto, ${ }^{\circ}{ }^{512,3}$ de Jun. 1937, 142 p.

Uma explicação, n. ${ }^{\circ}$ 514, 19 de Jun. 1937, 182-197 pp.

Notazinha ao artigo de Abel Salazar, n. ${ }^{\circ}$ 515, 26 de Jun. 1937, 208-211 pp.

Ainda o problema da divulgação, n. ${ }^{\circ}$ 515, 26 de Jun. 1937, 202-216 pp.

Sobre o método mais próprio para converter o incréu, $n{ }^{\circ} 515,26$ de Jun. 1937, 215-216 pp.

Palavras a Abel Salazar, n. ${ }^{\circ}$ 515, 26 de Jun. 1937, 216-217 pp.

O português e a cultura, n. ${ }^{\circ} 516,3$ de Jul. 1937, 222 p.

Cartesianismo ideal e cartesianismo real - I, n. ${ }^{\circ} 517,10$ de Jul. 1937, 243-247 pp.

Ainda a vulgarização, n. ${ }^{\circ}$ 517, 10 de Jul. 1937, 242, 257-258 pp.

Sobre o método mais próprio para converter o incréu, n. ${ }^{\circ} 518,17$ de Jul. 1937, 262, 273-274 pp.

Cartesianismo ideal e cartesianismo real - II, n. ${ }^{\circ}$ 519, 24 de Jul. 1937, 285-288 pp.

Explicação e reprovação de uma desmesura própria, $n .^{\circ}$ 519, 24 de Jul. 1937, 282 p.

Cartesianismo ideal e cartesianismo real - III, n. ${ }^{\circ}$ 520, 31 de Jul. 1937, 307-309 pp.

Sobre o sistema cooperatista, n. ${ }^{\circ}$ 522, 14 de Ag. 1937, 343-344 pp.

Notas a Protecionismo e cooperatismo de Carlos Gide (traduzidas sob o pseudónimo de Álvaro de Clarival), n. ${ }^{\circ} 524,28$ de Ag. 1937, 394 p.

Línguas brasileiras faladas e língua brasileira escrita, línguas portuguesas faladas e língua portuguesa escrita. (Palavras de um cidadão do mundo, humanista critico, a um estudante brasileiro seu amigo), n. ${ }^{\circ} 525,4$ de Set. $1937,404-410$ pp.

Viver com ideias, $\mathrm{n} .{ }^{\circ} 531,16$ de Out. $1937,43-44 \mathrm{pp}$.

Um pedido e uma promessa, n. ${ }^{\circ}$ 536, 20 de Nov. 1937, 177 p.

Temas para meditação, n. ${ }^{\circ}$ 537, 27 de Nov. 1937, 196-197 pp.

Introdução actual ao programa cooperatista, n. ${ }^{\circ} 539,11$ de Dez. 1937, 236-243 pp.

Explicação aos leitores da «Seara Nova» (não assinado), n. ${ }^{\circ} 539,11$ de Dez. 1937, 243 p.

1938

Em torno de um complicado caso de consciência, $n .^{\circ} 543,8$ de Jan. 1938, 337-340 pp.

Resposta a uma consulta, n. $.^{\circ} 544,15$ de Jan. 1938, 365-366 pp.

Resposta a uma consulta, n. ${ }^{\circ}$ 545, 22 de Jan. 1938, 390-391 pp.

(Transcrição de um depoimento sobre a pena de morte), $n .{ }^{\circ} 547,5$ de Fev. 1938, 22 p.

Os processos de traição na Rússia, n. ${ }^{\circ}$ 553, 19 de Março 1938, 156 p. 
Sobre algumas imbecilidades (e não-imbecilidades) que continuam a ser-me atribuídas, $n .^{\circ}$ 554, 26 de Mar. 1938, 167-169 pp.

Ainda em torno dos processos de traição na Rússia, n. ${ }^{\circ} 55,2$ de Abr. 1938, 201-202 pp.

Nota sobre o artigo de Raul Proença, n. $.^{\circ} 55,2$ de Abr. 1938, 205 p

Quatro pontos, n. ${ }^{\circ}$ 557, 16 de Abr. 1938, 239-241 pp.

A polémica da "Arte Humana» e da "Arte deshumana", n. ${ }^{\circ}$ 557, 16 de Abr. 1938, 255-256 pp.

Sobre Viana da Mota e a sua saída do Conservatório, n. ${ }^{\circ} 559,30$ de Abr. 1938, 288 p.

Sobre a interpretação de dois sonetos célebres, $n .^{\circ} 560,7$ de Maio 1938, 313-314 pp.

Palavras escritas há mais de vinte anos. Carta a um amigo, durante a guerra, n. ${ }^{\circ} 565,11$ de Junho 1938, 3-5 pp.

(Nota a um opúsculo sobre a tecnocracia), n. ${ }^{\circ} 565,11$ de Junho 1938, $9 \mathrm{p}$.

Resposta a uma consulta, n. ${ }^{\circ}$ 570, 16 de Jul. 1938, 121-122 pp.

Notas sobre Fernão Mendes Pinto, n. $.^{\circ} 71,23$ de Jun. 1938, 153-156 pp.

Solução do problema social pelas régies cooperativas, $\mathrm{n}^{\circ} 572,30 \mathrm{de}$ Jul. 1938, 167 p.

$O$ ateísmo, Voltaire e os gangsters, n..$^{\circ}$ 573, 6 de Ag. 1938, 208 p.

Genealogia intelectual, $\mathrm{n} .^{\circ} \mathbf{5 8 0}, 24$ de Set. 1938, 357-376 pp.

Anti-dogmatismo e cooperatismo, n. ${ }^{\circ} 582,8$ de Out. 1938, 416 p.

Est modus in rebus, n. ${ }^{\circ} 53,15$ de Out. 1938, 16 p.

Treze pontinhos, n. ${ }^{\circ}$ 585, 29 de Out. 1938, 43-44 pp.

(Notícia crítica à obra: Subsídios para uma história da filosofia do direito em Portugal, de L. Cabral de Moncada. Coimbra, 1938), n. ${ }^{\circ} 587,12$ de Nov. 1938, 105-106 pp.

Sobre o odioso «eu», n. ${ }^{\circ} \mathbf{5 8 8}, 19$ de Nov. 1938, 123-125 pp.

A Academia, a literatura, a disciplina mental e a gramática, n. ${ }^{\circ} 592$, 17 de Dez. 1938, 195-198 pp.

Racionalismo e gramática, vitoriosos e derrotados, $n .^{\circ}$ 593, 24 de Dez. 1938,231 p.

História do Natal e do Ano Bom. O regresso do filho pródigo, n. ${ }^{\circ} 594$, 31 de Dez. 1938, 239 p.

\section{9}

O antagonismo interno no cristianismo histórico. (Transcrição do n. ${ }^{\circ}$ 24 de «O Diabo»), n. ${ }^{\circ} 595,7$ de Jan. 1939, 258 p.

Pequena tentativa de dissipar duas confusões mentais e de esclarecer um espírito apaixonado, $\mathrm{n} .^{\circ}$ 597, 21 de Jan. 1939, 303-306 pp.

Sobre $A$ Vida de Lincoln, de Agostinho da Silva, n..$^{\circ}$ 598, 28 de Jan. 1939, 322 p.

(Notícia crítica a propósito do livro "Os Fins do Estado", de Afonso Rodrigues Queiró. Coimbra, 1938), n. ${ }^{\circ}$ 599, 4 de Fev. 1939, 356-357 pp.

Cultura, n. ${ }^{\circ}$ 600, 11 de Fev. 1939, 362 p.

Ainda a vernaculidade e o Prémio Malheiros, n. ${ }^{\circ} 601,18$ de Fev. 1939, 2-17 pp.

Mais confusôes mentais e mais pessoalismo, n. ${ }^{\circ} 601,18$ de Fev. 1939, 8-11 p.

O cristianismo de Jesus, o cristianismo histórico e a paixão de atacar

e descompor, nn. ${ }^{\circ} 62,25$ de Fev. 1939, 22-35 pp.
À margem da gramática, n. 603,4 de Mar. 1939, $57-58$ (não assinado)

O regime da distribuição da abundância ou o reinado do consumidor, n. ${ }^{\circ}$ 604, 11 de Mar. 1939, 66 p. 
Num mundo onde se vive na miséria havendo todas as condições para a abundância. A idea de uma conferência internacional económica, n. ${ }^{\circ}$ 604, 11 de Mar. 1939, 77 p.

Num mundo onde se vive na miséria havendo todas as condições para a abundância. Fundou-se em França o Sindicato Nacional dos Consumidores, ${ }^{\circ}{ }^{\circ} 605,18$ de Mar. 1939, 95 p.

$A$ crise, n. ${ }^{\circ}$ 605, 18 de Mar. $1939,95-96$ pp.

Vida social moderna com vida escolar à antiga, n. ${ }^{\circ} 609,15$ de Abr. $1939,177 \mathrm{p}$.

Carta de A. Sérgio ao Director-Gerente da Empresa "Seara Nova" demitindo-se de co-director da revista, n. ${ }^{\circ}$ 618, 17 de Jun. 1939, 346 p.

1947

Luís Verney apóstolo cívico, n. ${ }^{\circ}$ 1016-1017, 25 de Jan. 1947, 35-38 pp.

1951

Uma carta de A. Sérgio, n. ${ }^{\circ}$ 1224-1225, 7 e 14 de Jul. 1951, 520-523 pp.

Trechos escolhidos, ${ }^{\circ}{ }^{\circ}$ 1240-1241, 1, 8 e 15 de Dez. 1951, 650-651 pp.

1956

A cultura portuguesa, n. ${ }^{\circ}$ 1319-1320, Maio 1956, 62-65 pp.

Uma representação ao Chefe do Estado (assinado por A. Sérgio e pelo prof. Mário de Azevedo Gomes), n. ${ }^{\circ}$ 1323-1324, Jul. 1956

1969

Um inédito de António Sérgio, n. ${ }^{\circ}$ 1481, Mar. 1969, 87 p. (poesia)

Nota: - Sob o pseudónimo de Álvaro de Clarival publica a Seara Nova as poesias seguintes:

Firmamento interior, ${ }^{\circ}$ 398, 10 de Maio 1934, 52 p.

Eutaxia, n. ${ }^{\circ}$ 392, 7 de Jun. 1934, 124 p.

Voz do crepúsculo, n. ${ }^{\circ}$ 394, 21 de Jun. 1934, 155 p.

Panoramas do Oriente, n. ${ }^{\circ} 412,25$ de Out. 1934, 60-61 pp.

Nevoazinhas de Paris, ${ }^{\circ}$ 437, 30 de Maio de 1935, 76 p.

Recordações de Watteau, n. ${ }^{\circ} 49,29$ de Ag. 1935

Canção do velho da Horta, n. ${ }^{\circ} 451,12$ de Set. 1935

Maré enchente, ${ }^{\circ}{ }^{\circ} 455,10$ de Out. 1935, 362 p.

Nota: - A identificação que referimos da colaboração de A. Sérgio na Seara Nova, não assinada, feita por V. Magalhães Vilhena, foi extraída da obra deste autor intitulada: António Sérgio o Idealismo Crítico e a Crise da Ideologia Burguesa. Seara Nova, 1964

SERÕES - A revista Serões, Revista Mensal Ilustrada (Lisboa, 1901-1911) adopca a direcção literária de António Sérgio, a partir do n. 67 de Jan. de 1911, assim permanecendo até final da sua publicação, ou seja, até Dezembro de 1911 (n. ${ }^{\circ}$ 78). Não aparece nunca colaboraçã̃o sua assinada. Pendemos a crer, todavia, que a secção Notícia Bibliográfica dos n.os 68,69 e 72, de Fev., Mar. e Jun. de 1911, se deve atribuir à sua autoria. 
SÍNTESE - Revista Mensal de Cultura. Directores: João Ramiro e Ramiro da Fonseca. Duração: 1939-1941. Números publicados: 13. Local de publicação: Coimbra

Cultura, n. ${ }^{2}$, Fev. 1939, 30-31 pp.

SOL NASCENTE - Quinzenário de Ciência, Arte e Crítica. Comissão directiva: Carlos F. Barroso, Lobão Vital e J. Soares Lopes. Duração: 1937-1940. Números publicados: 45. Local de publicação: Porto

Dialoguete. No tribunal da História, n. ${ }^{\circ}$ 2, 15 de Fev. 1937, 7 p.

Fim de uma polémica (transcrição da Seara Nova, n. 519 de 24 de Jul. de uma nota de A. Sérgio com o título: Explicação e reprovação de uma desmesura própria), n. ${ }^{\circ} 12,1$ de Ag. 1937

TERRA MÃE — Semanário regionalista. Pombal

Em vésperas de combate. A Abissínia e a sua História, 29 de Set., 1935

Em vésperas de combate. A Abissínia e a sua História, 3 de Nov., 1935

Em vésperas de combate. A Abissínia e a sua História, 24 de Nov., 1935

Roteirinho do leitor de romances, 8 de Nov., 1936

TERRA DE SOL - Rio de Janeiro

Camões, n. ${ }^{\circ} 11-12,1924,156-163$ pp. (palestra mais tarde reformulada no artigo «Em torno das ideias políticas de Camões», Ensaios IV)

UNICÓRNIO, BICÓRNIO, TRICÓRNIO, TETRACÓRNIO E PENTACÓRNIO - Antologia de Inéditos de Autores Portugueses Contemporâneos. Director: José Augusto França. Números publicados: 5. Local de publicação: Lisboa

Em torno do problema da importância dos escritores na sociedade portuguesa, Pentacórnio, 31 de Dez. 1956, 3-7 pp.

VER E CRER - Director: José Ribeiro dos Santos e Mário Neves. Duração: Maio 1945-Abril 1950: Números publicados: 57. Local de publicação: Lisboa

A realidade é o que se vê ou é o que se supõe?, n. ${ }^{\circ}$ 13, Maio de 1946, 35-42 pp.

VÉRTICE Revista de Cultura e Arte. Director: Raúl Gomes. Local de publicação: Coimbra

Nota a um passo de uma introdução a Berkeley,.$^{\circ} 17$ a 21, (fase. 4), Nov. de 1945, 42-48 pp.

Réplica sem severidade a um severo amigo, n. ${ }^{\circ} 27$ a 30, (fase. 6), Mar. de 1946, 42-61 pp.

António Sérgio responde ao nosso Inquérito,.$^{\circ} 30$ a 35, (fase. 7), Maio de 1946, 158, 159, 160, 161 pp. 
Explicações para os que entendem a língua que eu falo, $n .^{\circ} 36$ a 39 (fasc. 8), Jun. de 1946, 214-232 pp.

Diálogo com Antonio Sérgio, n. ${ }^{\circ} 153$, Jun. de 1956, 269-273 pp.

(Número de homenagem a Bento de Jesus Caraça onde se reeditam os três primeiros artigos atrás citados), n. ${ }^{\circ}$ 301-302-303, Out.-Dez. 1968

A VIDA PORTUGUESA - Quinzenário de Inquérito à Vida Nacional. Director: Jaime Cortesão. Duração: de 31 de Out. de 1912 a 2 de Nov. de 1915. Números publicados: 39. Local de publicação: Porto

Variações do amigo banana, amador de estudos históricos, sobre Inquisição e Humanismo; divulgadas para entretem dos ociosos por um seu familiar indiscreto e também amador dos ditos estudos, ${ }^{\circ}{ }^{\circ} 4,15$ de Dez. 1912

Carta a José Fagundes, poeta lírico, sobre o bacharel e suas causas, n. ${ }^{\circ} 12,17$ de Abr. 1913

Golpes de malho em ferro frio. Aos portugueses de dezasseis anos que não ambicionam ser poetas líricos, $n{ }^{\circ} 16,2$ de Ag. 1913, 121-128 pp.

O parasitismo peninsular. Carta a Jaime Cortesão, n. ${ }^{\circ} 20,1 \mathrm{de}$ Dez. 1913, 153-159 pp.

O livre-câmbio I, n. ${ }^{\circ} 21,15$ de Jan. 1914, 2-3 pp.

O livre-câmbio II, n. ${ }^{\circ} 22,10$ de Fev. 1914, 9-10 pp.

O problema da cultura, $.^{\circ} 23,1$ de Mar. 1914, 21-22 pp.

Nota a propósito da criação da «Biblioteca de Educação»" dirigida por António Sérgio, n. ${ }^{\circ}$ 27, Jul. 1914, 49 p.

A implantação da indústria do ferro em Portugal, n. ${ }^{\circ} 28$, Ag. 1914, 57-58 pp.

Em que o autor, sem dar por isso demonstra a conveniência de se reimprimir a Arte de Furtar lentíssimo em que o recatado doutrina, n. ${ }^{\circ} 30$, Out. 1914, 74-75 pp.

Em que o autor, sem dar por isso demonstra a conveniência de se reimprimir a Arte de Furtar doPadre Vieira, discurso excelentissimo em que o recatado doutrina, n. ${ }^{\circ} 31$, Nov. 1914, 81-83 pp.

Uma página de Castilho, n. ${ }^{\circ} 33$, Jan. 1915, 97-98 pp.

VIDA MUNDIAL — Director: Carlos Ferrão. Lisboa

Carta escrita por António Sérgio a José Régio a propósito de Encruzilhadas de Deus, ${ }^{\circ} 1633,25$ de Set. de 1970, 68 p.

\section{Ic PREFÁCIOS, NOTAS E ORGANIZAÇÃO DE EDIÇÕES}

Sérgio, Luisa - O Método Montessori (advertência). Porto, Renascenca Portuguesa, 1915, 142 p.

Castilho, Artur Manual de instrução agrícola na escola primária (compilação e adaptação). Advertência cujo texto é o das Considerações histórico-pedagógicas. Porto, Renascença Portuguesa, 1916, 201 p. 
Coelho, Adolfo - Cultura e analfabetismo. (Prefácio). Porto, Renascença Portuguesa, 1916, $107 \mathrm{p}$.

Le Châtelier-Indústria e Ciência. (Prefácio). Porto, Renascença Portuguesa, 1917, $62 \mathrm{p}$.

Contribuição para o estabelecimento de uma escala de pontos dos níveis mentais das crianças portuguesas. (Explicação prévia e colab. com Luisa Sérgio). Porto, Renascença Portuguesa, 1919, $98 \mathrm{p}$.

Bernardes, Manuel - Histórias várias (Da «Nova Floresta»). Nota Preliminar, não assinada. (Por inf. de Castelo Branco Chaves). Rio de Janeiro, Annuário do Brasil, 1920, 134 p.

Martins, Oliveira - Dispersos. Artigos politicos, económicos, filosóficos, históricos e críticos. Selecção, prefácio e notas. (De colab.). Lisboa, Biblioteca Nacional, 1923-24, 2 vols.

Antologia dos economistas portugueses. (Selecção, prefácio e notas). Séc. XVII. Obras em português. Lisboa, Publicações da Biblioteca Nacional, 1924, 392 p. 2.a ed. Lisboa, Livr. Sá da Costa, 1974, 226 p.

Murché, Vincent - Curso sistemático de lições de coisas. (Prefácio). Lisboa, Liga Portuguesa da Instrução em Portugal, 1926, 219 p.

Abreu, Casimiro de - Cantos de Amor. (Prefácio). Paris, Casa Editorial Franco-Ibero-Americana, s. d. (1928?), 160 p.

Abreu, Casimiro de - Cantos de tristeza e de saudade. (Prefácio). Paris, Casa Editorial Franco-Ibero-Americana, s. d. (1928?), 158 p.

Camões, Luís de - Odes, éclogas, elegias e canções. Prefácio e selecção. Paris, Livraria Francesa e Estrangeira Truchy-Leroy, s. d., 2 vols. «Biblioteca Miniatura», 159, $151 \mathrm{pp}$.

Ferrière, Adolfo - Transformemos a escola. Apelo aos pais e às autoridades. (Prefácio). Paris, Livraria Francesa e Estrangeira, Truchy-Leroy, 1928, 239 p.

Camões, Luís de - Redondilhas. (Prefácio e selecção). Paris, Casa Editorial Franco-Ibero-Americana, s.d. (1929?), «Biblioteca Miniatura», $174 \mathrm{p}$.

Camões, Luiz - Liricas escogidas. Universidade de Santiago de Compostela, Publicaciones dei Instituto de Estúdios Portugueses, 1933, 48 p.

Quental, Antero de - Sonetos Escogidos (Prefácio e selecção). Santiago de Compostela. Publicaciones dei Instituto de Estúdios Portugueses, 1933, $30 \mathrm{p}$.

Almeida, Vieira de - Lacrima rerum. II - Nocturna (Prefácio). Lisboa, Seara Nova, 1934.

História trágico-marítima. Narrativa de naufrágios da época das conquistas. (Adaptação). Lisboa. Livraria Sá da Costa Editora,

1934. Ilust. 2. a ed.: Lisboa, Livraria Sá da Costa Editora, 1942. Ilust. 3. a ed.: Lisboa, Livraria Sá da Costa Editora, 1951. Ilust. 4a ed.: Lisboa, Livraria Sá da Costa Editora, 1957. Ilust. 5a ed.: Lisboa, Livraria Sá da Costa Editora, 1962. Ilust.

Chaves, Castelo Branco - Raul Brandão. (Advertência). Lisboa, Seara Nova, 1934. «Estudos Literários», 31 p.

Melo, Francisco Manuel de — D. Manuel de Meneses. (Da «Epanáfora trágica»). Prefácio e notas. Lisboa, Seara Nova, 1936. "Textos Literários», 30 p.

Melo, Francisco Manuel de - Relógios falantes (Apólogo dialogai). Com prefácio e notas. Lisboa, Seara Nova, 1936. "Textos Literários», 2.a ed.: Lisboa, Seara Nova, 1938. «Textos Literários». 3. a ed.: Lisboa, Livraria Sá da Costa Editora, 1940. «Clássicos do Estudante» 
Barros, João de O descobrimento do caminho da índia (Livro IV

Década I). Prefácio e notas. Lisboa, Seara Nova, 1936. «Textos Literários». 2a ed.: Lisboa, Seara Nova, 1936. «Textos Literários». 3." ed.: Lisboa, Seara Nova, 1938. «Textos Literários». 4. a ed.: Lisboa, Livraria Sá da Costa Editora, 1939. «Clássicos do Estudante». 5a ed.: Lisboa, Livraria Sá da Costa Editora, 1940. «Clássicos do Estudante»

Herculano, Alexandre - Sobre história e historiografia (Da «História de Portugal» e dos "Opúsculos»). Selecção, prefácio e notas. Lisboa, Seara Nova, 1937. "Textos Literários», 138 p.

Vieira, António_Sobre as verdadeiras e falsas riquezas (sermão da l.a oitava da Páscoa). Prefácio e notas. Lisboa, Seara Nova, 1937. «Textos Literários», 56 p.

Vieira, António - Sermão sobre a paz (sermão da Segunda Oitava da Páscoa, pregado em Roma). Prefácio e notas. Lisboa, Seara No$v a$, 1937. «Textos Literários». 2.a ed.: Lisboa, Seara Nova, 1938. «Textos Literários», 70 p.

Ortigão, Ramalho - As origens da Holanda (De "A Holanda»). Prefácio e notas. Lisboa, Seara Nova, 1937. «Textos Literários», 53 p.

Gide, Carlos - O programa cooperatista. (Prefácio). Lisboa, Seara Nova, 1937-39, 2 vols. «Textos Económico-Sociais».

Pinto, Fernão Mendes - Peregrinação. Episódio da busca do corsário Coja Acem. (Prefácio e notas). Lisboa, Seara Nova, 1938. «Textos Literários», $143 \mathrm{p}$.

Lavergne, Bernard - Régies Cooperativas em Inglaterra. (Nótula preambular). Lisboa, Seara Nova, 1938. «Estudos políticos e sociais", 23 p.

Dinis, Júlio - As pupilas do Senhor Reitor. Trechos escolhidos e apresentados em inserção num resumo da novela. Lisboa, Livraria Sá da Costa Editora, 1940. «Clássicos do Estudante», 179 p.

Camões, Luís de - Os Lusíadas. Os seus mais belos trechos, apresentados em inserção num resumo do poema. Lisboa, Livraria Sá da Costa Editora, 1940. "Clássicos do Estudante», 141 p.. 2. ${ }^{a}$ ed. Lisboa, Livr. Sá da Costa, 1976, 124 p.

Freyre, Gilberto - O mundo que o português criou. Aspectos das relações sociais e de cultura do Brasil com Portugal e as colónias portuguesas. Prefácio. Rio de Janeiro, José Olympio Editora, 1940, «Documentos Brasileiros», $n .^{\circ} 28,164$ p. l.a ed. portuguesa: Lisboa, Livros do Brasil, L.da, s. d. (1951?), «Colecção Livros do Brasil», n. ${ }^{\circ}$ 16. 2. ${ }^{a}$ ed. portuguesa: Lisboa, Livros do Brasil, L.da, s. d., "Colecccão Livros do Brasil», n. ${ }^{\circ} 16$

Quental, Antero - Obras. Sonetos, Primaveras Românticas e Odes Modernas. Edição organizada, prefaciada e anotada. Lisboa, Couto Martins, 1941-43, 3 vols. 2. ${ }^{\text {a }}$ ed.: Lisboa, Couto Martins, 1943$-52,3$ vols. $3^{\text {a }}$ ed.: Sonetos, Lisboa, Couto Martins, 1956

Lopes, Ferrão - Crónica de D. João I (prefácio). Biblioteca Histórica-Série Régia, Porto, Livr. Civilização, 1945, 2 vols.

Agudo, J. Dias - A criança e a educação. (Prefácio). Lisboa, Editorial Gleba, L.da, 1945, 296 p.

Crossman, H. S. - Foot, Michael - A Palestina outro Munique? (Prefácio). Lisboa, Editorial Inquérito, L.da, 1946, 64 p.

Prosa doutrinal de autores portugueses. (Selecção, prefácio e notas). Lisboa, Portugália Editora, s. d., 1947, 467 p. 2a ed.: Lisboa, Portugália Editora, 1965. "Antologias Universais - Ensaio», 1

Vieira, António - Obras escolhidas. Prefácio, selecção e notas nos vol. I e II, Cartas. Restantes vols, de responsabilidade de Hernani 
Cidade. Lisboa, Livraria Sá da Costa Editora, 12 vols. «Colecção Clássicos Sá da Costa», 1951.

Martins, Oliveira - Teoria do socialismo. Evolução política e económica das sociedades na Europa. (Prefácio). Lisboa, Guimarães \& C.. , 1952, 323 p.

Martins, Oliveira - Portugal e o socialismo. (Prefácio). Lisboa, Guimarães \& C. a, 1953, 232 p.

Estatuto da UNICOOPE. União Cooperativa Abastecedora. (Prefácio). Coimbra, s. e. (Tipografia Loio), 1955

Indicador Cooperativo - (Prefácio) Porto, ed. Imprensa Social (Secção da Cooperativa do Povo Portuense) 156, 31 p.

História trágico-marítima. Anotada, comentada e acompanhada de um estudo. Lisboa, Editorial Sul, Limitada, 1956-57, 3 vols.

Costa, Fernando Ferreira da $-\mathrm{O}$ movimento cooperativo britânico. (Prefácio). Porto, ed. do Autor, 1956, 3-8 p.

Vilela, António Lobo - Do sentido Cómico e Trágico da Vida. (Prefácio). Lisboa, s. e., 1956.

Quental, Antero- Cartas (Cartas cujo principal assunto é de natureza filosófica), prefácio. Lisboa, Couto Martins, 1957, 158 p.

Naufrágios e combates no mar. Textos seleccionados, anotados, comentados e acompanhados de um estudo. Lisboa, Editorial Sul, Limitada, 1958-59, 2 vols.

Cardoso Júnior, F. J. - Em prol da educação popular. (Colectânea de doutrinas). Prefácio, Porto, Ed. Marânus, 1960, 172 p.

Quental, Antero de - Sonetos. Edição organizada, prefaciada e anotada. Lisboa, Livraria Sá da Costa Editora, 1962. «Colecção de Clássicos Sá da Costa». 2 a ed.: Lisboa, Livraria Sá da Costa Editora, 1963. "Coleccão de Clássicos Sá da Costa» ..3a ed.: Lisboa, Livraria Sá da Costa Editora, 1968. «Colecção de Clássicos Sá da Costa»

Branco, João de Freitas - Viana da Mota (Prefácio). Lisboa, ed. Fundação Gulbenkian, 1972, 1-8 pp.

\section{Id COLABORAÇÃO EM OBRAS COLECTIVAS}

Ferro, António - Mar alto. Peça em 3 actos. (Colab. em Nota final intitulada $" O$ protesto dos intelectuais portugueses». Lisboa, Livraria Portugália, 1923, 205 p.

O jogral de Deus. In Correia, Joaquim Alves e outros - Em louvor de S. Francisco. Braga, s. e., 1927

Manifesto ao Paiz. Colab. de: Afonso Costa, Álvaro de Castro, Domingos dos Santos e Jaime Cortesão. Paris, 3 de Dez. 1927, 1 p.

Reis, Emma Romero Santos Fonseca da Câmara - Divulgação musical. (Colab. Os quatro de Espanha, vol. II, 529-537 pp.; A canção popular pelo mundo fora, vol. III, 95-103 pp.; Cançóes de bordo, vol. III, 353-361 pp.; Música do renascimento, vol. IV, 337-346 pp.; Canções das provincias de Espanha, vol. V, 287 a 291 pp. Lisboa, s. e., 1929-40, 5 vols.

Notas sobre a imaginação, a fantasia e o problema psicológico-moral na obra novelística de Queiroz. In Livro do Centenário de Eça de Queiroz. Lisboa, Livros do Brasil, L.da, 1945, 717 p. 
A idea da liberdade, in Álvaro de Castro, In Memoriam, Lisboa, s. e., 1947

Depoimento contra depoimento. Comentários a certos conceitos volíticos à luz da minha experiência pessoal. (De colab.). Lisboa, Serviços Centrais da Candidatura, 1949, $63 \mathrm{p}$.

A Teixeira de Pascoais. Homenagem da Academia de Coimbra pela voz de escritores portugueses $e$ brasileiros. (Colab.). Coimbra, Associação Académica, 1951

Viana da Mota. Sobre o universalismo integrante da sua visão das coisas. In Viana da Mota. In Memoriam. Lisboa, s. e., 1952.

Um problema a propósito de certa resposta de Santa Clara. In Augusto, Armindo - Em louvor de Santa Clara, 1253-1953. Braga, s. e., 1954

Nobreza de Portugal e do Brasil. (Colab.). Lisboa, Editorial Enciclopédia, L.da, 1960-61, 3 vols.

Grande fabulário de Portugal e do Brasil. (Colab.). Lisboa, ed. Artísticas Fólio, 1961-62, 2 vols. Ilust.

GRANDE ENCICLOPÉDIA PORTUGUESA E BRASILEIRA - Direccão: Prof. Dr. António Mendes Correia e outros. Local de publicação: Lisboa. Vol, I, 1935

Colaboração Vária, não assinada

\section{Ie EPISTOLÁRIO}

\section{el EM LIVROS E OPÚSCULOS}

Azevedo, Manuela de - «António Sérgio (1883-1969)», Cartas Políticas a Joũo de Barros, Lisboa, Imprensa Nacional Casa da Moeda, 1982, 292-302 pp. (contém 4 cartas de A. S. de 1927, 1932 e 1953 e uma notícia biográfica)

Comissão do livro negro sobre o regime fascista - Eleições presidenciais de 1951 e correspondência entre Oliveira Salazar e Craveiro Lopes, Lisboa, Presidência do Conselho de Ministros, 1983. (Contém: cartão manuscrito do Ministro do Interior dirigido a Salazar c/ ref. ${ }^{a}$ a A. S. 49-50 pp.; documenco sobre a candidatura do Almirante Quintão Meireles, c/ ref. ${ }^{a}$ a A. S., 51-52 pp.; cópia de uma carta dirigida por A. S. a um amigo do Porto, encontrada no arquivo de Salazar, 104-105 pp.; «informação» recebida por Salazar sobre A. S., 110 p.; carta de Craveiro Lopes c/ ref. a a A. S. 166 p.)

Fernandes, H. J. Barahona - A propósito da expressão numérica de uma medida em física, com uma carta inédita de António Sérgio, Lisboa, Memórias da Classe de Ciências, 1971

Fernandes, Rogério - Cartas de António Sérgio a Álvaro Pinto (1911-1919), Lisboa, ed. Revista Ocidente, 1972, 72 p. (Com introdução e notas) 
«Epistolário da Biblioteca Municipal de Coimbra. De António Sérgio a Manuel da Silva Gaio", Coimbra, Arquivo Coimbrão. Boletim da Biblioteca Municipal, 1970, 331 a 376 pp. (40 cartas, entre 1911 e 1933)

Pedroso, Alberto - «Uma carta inédita de António Sérgio. Em torno das suas objecções quanto aos fins da Universidade Popular», A Cidade, Revista Cultural de Portalegre, n. ${ }^{\circ}$ 3, Fev. 1982.

«António Sérgio», Carta de 1 de Fev. 1932. Colóquio, (Letras), n. ${ }^{\circ} 16$ Nov. 1973, 49-50 pp.

Branco, Fernando Castelo e Pedro da Silveira - «Cartas inéditas de Guerra Junqueiro, Raul Brandão, Afonso Duarte e António Sérgio», Colóquio (Letras), n. ${ }^{\circ} 16$, Nov. 1973, 49-50 pp. ${ }^{\wedge}$

Fernandes, Rogério - «Duas cartas inéditas de António Sérgio para Afonso Lopes Vieira», Colóquio (Letras), n. ${ }^{\circ}$ 46, Nov. 1978, 57-65 pp.

Fernandes, Rogério - «Cartas inéditas de António Sérgio a João Osório de Oliveira», Colóquio (Letras), n. ${ }^{\circ}$ 59, Jan. 1981, 42-45 pp.

\section{Correspondência António Sérgio - Bernardino Machado:}

Baptista, Jacinto - «Os Portugueses não sabem pensar, organizar e prever...- o ensaísta numa carta a Bernardino Machado». Correio do Minho, 15 de Jan., 1983

Baptista, Jacinto - «Quando António Sérgio no exílio procurava quaisquer meios de modestíssima subsistência». Correio do Minho, 22 de Jan., 1983

Baptista, Jacinto - «Socialização sem estatismo. A sociedade visionada por António Sérgio». Correio do Minho, 29 de Jan., 1983

Baptista, Jacinto - «Cartas inéditas a Bernardino Machado. António Sérgio propoe-se (em 1932) congraçar os adversários da ditadura». Correio do Minho, 5 de Fev., 1983. (Carta de 14.8.932)

Baptista, Jacinto - «Complicada a nossa vida de emigrados. - Luisa Sérgio (em 1932) a Bernardino Machado». (Carta de Luisa Sérgio de Sousa a Bernardino Machado comentada por Jacinto Baptista com, ainda: «A situação dos homiziados relatada pela A Situação»). Correio do Minho, 12 de Fev., 1983

Baptista, Jacinto - «Sérgio dizia a Bernardino Machado em 1932 Não sei que lhes hei-de fazer, (Aos combatentes fugidos de Timor e falhos de recursos). Correio do Minho, 19 de Fev., 1983

Baptista, Jacinto - «Quando António Sérgio se julga com direito a uma demissãozinha». Correio do Minho, 26 de Fev., 1983. (Carta de 21.9.1932)

Baptista, Jacinto - «Estudantes e gente pobre - naturalmente contra a ditadura». (Carta de 13.10.1932. Em apêndice: "Vitorino Nemésio em sintonia com os emigrados de Paris", c/ referências a A. S.). Correio do Minho, 5 de Mar., 1983

Baptista, Jacinto - «Acção! Acção! Acção! Bernardino Machado faz sua uma exortação revolucionária de Ribeiro de Carvalho». (Carta inédita de Bernardino Machado ao militar republicano Ribeiro de Carvalho, que Jacinto Baptista considera como texto de apoio à correspondência epistolar Sérgio - Bernardino Machado). Correio do Minho, 26 de Mar., 1983

Baptista, Jacinto - «Citando Malaparte. Ofensiva técnica contra a di- 
tadura, alvitra Antonio Sérgio aos chefes políticos». Correio do Ie Minho, 3 de Abr., 1983

Baptista, Jacinto - «Onde se fala de inclusos e de exclusos de uma amnistia entre aspas» (carta de 15.12.1932). Correio do Minho, 9 de Abr., 1983

Baptista, Jacinto - «António Sérgio quer responder às baboseiras de Salazar» (carta de 27.12.1932). Correio do Minho, 16 de Abr., 1983

Baptista, Jacinto - «António Sérgio no limiar de 33: vejo-me numa encruzilhada» (carta de 2.1.1933). Correio do Minho, 23 de Abr., 1983

Baptista, Jacinto - «António Sérgio derrota em Genebra o grande empréstimo externo da ditadura» (carta de 2.9.1933). Correio do Minho, 1 de Maio, 1983

Baptista, Jacinto - «Sérgio utiliza processos artesanais para derrotar a ditadura em Genebra». Correio do Minho, 14 de Maio, 1983

Baptista, Jacinto - «A ditadura derrotada por Sérgio no exterior desencorajada por Salazar no interior». Correio do Minho, 22 de Maio, 1983

Baptista, Jacinto- «Os homens caem por falta de dinheiro pensa António Sérgio em 1928». Correio do Minho, 28 de Maio, 1983

Baptista, Jacinto - «Para responder às entrevistas de Salazar a António Ferro coagido à auto-censura .Correio do Minho, 12 de Jun., 1983

Baptista, Jacinto - «Há esperanças de vermos acabar a ditadura?» (carta de 27.2.1933). Correio do Minho, 18 de Jan., 1983

Baptista, Jacinto - «O grande empréstimo reconstruído através do epistolário António Sérgio - Bernardino Machado, encaixam-se mais duas peças do puzzle». Correio do Minho, 23 de Jul., 1983

«Uma carta de António Sérgio a propósito de uma crítica que lhe fizeram no Diário da Manhã»". Diário de Lisboa, 16 de Jul., 1951

«Uma carta de António Sérgio a Câmara Reis» (c/ notícia sobre a ed. crítica da Obra Completa de A. S.). Diário de Lisboa, 4 de Dez., 1970

«Uma carta do sr. dr. António Sérgio» (esclarecimento ao Ministro do Interior). Diário Popular, 15 de Out., 1953

«Documentação inédita de excepcional valor para a história da oposição democrática à ditadura - Cartas de António Sérgio a Sarmento Pimentel publicadas pelo dr. Jacinto Baptista no Diário Popular

\section{(1. ${ }^{a}$ SÉRIE)}

\begin{tabular}{|c|c|c|c|c|c|c|c|c|c|c|c|}
\hline Carta & de & Paris & de & 15 & de & Abr, & 927 & - & 3 de & ar, & 977 \\
\hline 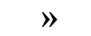 & " & $»$ & 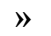 & 17 & de & Abr, & 1927 & - & 10 de & r, & 1977 \\
\hline 》 & " & 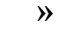 & " & 17 & de & $\begin{array}{l}\text { Maio, } \\
\text { Set }\end{array}$ & 1927 & - & 17 de & Mar, & $\begin{array}{l}1977 \\
1077\end{array}$ \\
\hline & & & & $\begin{array}{r}4 \\
10\end{array}$ & $\begin{array}{l}\text { de } \\
\text { de }\end{array}$ & $\begin{array}{l}\text { Set, } \\
\text { Set, }\end{array}$ & 1927 & & $\begin{array}{l}24 \mathrm{de} \\
31 \mathrm{de}\end{array}$ & $\begin{array}{l}\text { Mar, } \\
\text { Mar, }\end{array}$ & 1977 \\
\hline & & & & 27 & de & Set, & 1927 & & $7 \mathrm{de}$ & Abr, & 1977 \\
\hline & & & & 16 & de & Ou & 19 & - & 14 de & $\mathbf{A b}$ & 1977 \\
\hline & & & & & & No & 19 & & $21 \mathrm{de}$ & $\mathbf{A b}$ & 1977 \\
\hline " & " & " & $"$ & $\begin{array}{l}27 \\
16\end{array}$ & de & Nov, & $\begin{array}{l}1927 \\
1027\end{array}$ & - & $28 \mathrm{de}$ & Abr, & $\begin{array}{l}1977 \\
1077\end{array}$ \\
\hline & & & & 18 & de & Ja & 19 & & $12 \mathrm{de}$ & Maio, & 19 \\
\hline & & & & ? & de & Jan & & & 19 de & , & 7 \\
\hline & & & & & & & & & $26 \mathrm{de}$ & 【aio, & 1977 \\
\hline
\end{tabular}


Carta de Paris de 16 de Mar., 1928 - 2 de Jun, 1977 28 de Mar., 1928 - 16 de Jun, 1977

(Assinada por Luisa

\begin{tabular}{|c|c|c|c|c|c|}
\hline " । & " & " & $\begin{array}{r}\mathbf{2 7} \\
\mathbf{2 5} \\
\mathbf{3 0} \\
\mathbf{3 0} \\
7 \\
\mathbf{1 5} \\
\mathbf{1 9} \\
\mathbf{2} \\
\mathbf{6} \\
\mathbf{3 0} \\
\mathbf{1 0} \\
\mathbf{2 8} \\
\mathbf{1 5} \\
28\end{array}$ & $\begin{array}{l}\text { de } \\
\text { de } \\
\text { de } \\
\text { de } \\
\text { de } \\
\text { de } \\
\text { de } \\
\text { de } \\
\text { de } \\
\text { de } \\
\text { de } \\
\text { de } \\
\text { de } \\
\text { de }\end{array}$ & $\begin{array}{l}\text { Abr., } \\
\text { Jun., } \\
\text { Jun., } \\
\text { Jul., } \\
\text { Ag., } \\
\text { Ag., } \\
\text { Ag., } \\
\text { Set, } \\
\text { Out, } \\
\text { Out, } \\
\text { Dez, } \\
\text { Dez, } \\
\text { Jan, } \\
\text { Jan, }\end{array}$ \\
\hline
\end{tabular}

$1928-23$ de Jun, 1977

$1928-30$ de Jun, 1977

19287 de Jul, 1977

1928 - 14 de Jul, 1977

$1928-21$ de Jul, 1977

$1928 \quad 28$ de Jul, 1977

1928 - 4 de Ag, 1977

$1928 \quad 11$ de Ag, 1977

1928 - 18 de Ag, 1977

$1928-25$ de Ag, 1977

$1928-1$ de Set, 1977

$1928 \quad 8$ de Set, 1977

$1929-15$ de Set, 1977

$1929-22$ de Set, 1977

Tassina também

Afonso Costa e

Jaime Cortesão)

\begin{tabular}{|l}
28 de Jan, \\
18 de Jul, \\
14 de Maio, \\
15 de Ag, \\
27 de Dez, \\
9 de Jan,
\end{tabular}

1929

29 de Set, 1977

1929 - 6 de Out, 1977

1930 - 13 de Out, 1977

1930 - 20 de Out, 1977

Carta $s / 1, s / d$

" " " " 15 de Ag, 1930

$1930 \quad 27$ de Out, 1977

" " " " " 9 de Jan, 1931 - 3 de Nov, 1977

Carta $s / 1$, 9 de Set,

- 10 de Nov, 1977

Carta de Lisboa de 25 de Jan,

$1938-17$ de Nov, 1977

" $" 26$ de Set,

$1939-24$ de Nov, 1977

1952 - 2 de Dez, 1977

-9 de Dez, 1977

\section{(2. a SÉRIE)}

«As coisas estão correndo bem para nós - escrevia de Paris em 1929 o ensaísta exilado pela ditadura»

«Interessado num emprego em S. Paulo (Brasil) até a ditadura cair»

_ 15 de Nov, 1979

- 22 de Nov, 1979

«Esperançado (em Junho de 1930) na iminente restauração da República»»

«Anuncia que sai da Seara Nova e critica Câmara Reis»

«Comunica a ideia de fazer da Seara uma revista nova»

«Dá notícias da nossa Gestapo»

"Aqui vai tudo na mesma»

«Há muitos meses que me não chega a Anhembi»

«Em 1952 O país não sabe nada de Macau»

«O inimigo ficou em desordem desde a nossa úlxima campanha eleitoral»»

«O Galvão tem-se portado admirabilissimamente»

- 29 de Nov, 1979

-6 de Dez, 1979

13 de Dez, 1979

- 20 de Dez, 1979

- 27 de Dez, 1979

3 de Jan, 1980

- 10 de Jan, 1980

- 17 de Jan, 1980

-31 de Jan, 1980 
«Na inércia é que não cairiei a não ser que adoeça»

«O regresso de Cortesão: Que seja para bem

12 de Jun., dele»"

«Que pensa do que se passa na Argentina?»

19 de Jun., 1980

«u sem novidade ainda sem sinais de caruncho»

Azevedo, Adalberto de - «Carta inédita de António Sérgio. Algumas considerações». Diário Popular, 4 de Out., 1979

Costa, F. Ramos da - «Uma carta inédita de António Sérgio sobre Lord Keynes». O Jornal, 16 de Fev. 1979

Baptista, Jacinto - "A imensíssima trindade do fascismo português", (c/ carta inédita a João Sarmento Pimentel, não datada, coetania ou posterior a 1953). $J L$, Jornal de Letras, artes e ideias, 31 de Ag., 1982

Baptista, Jacinto - «Dois democratas de escol» (Cartas inéditas de Bernardino Machado a António Sérgio). JL, Jornal de Letras, artes e ideias, $n .^{\circ} 57,26$ de Abr., 1983

Figueiredo, Matilde Pessoa de - «Cartas inéditas da Juventude». $J L$, Jornal de letras, artes e ideias, $n .^{\circ}$ 57, 26 de Abr., 1983

Fernandes, Rogério - «Cartas de António Sérgio a Álvaro Pinto (1911-1919). (Separata c/ o mesmo titulo, ed. da revista Ocidente, Lisboa, 1972, 72 p.) Ocidente, n. ${ }^{\circ}$ 413-414, Set.-Out., 1972

Machado, José Pedro - «Cartas dirigidas a David Lopes». (C/ nota introdutória e duas cartas de A. S. uma das quais e/ ref.as de importância a Herculano). Ocidente, n. ${ }^{\circ} 421$, Maio, 1973, 453$-457 \mathrm{pp}$.

«Carta de Nuno Simões a Sarmento Pimentel» datada de 19.8.1959 (refere-se à doença de A. S.). O Ponto, 22 de Jan., 1981

«Carta inédita de António Sérgio a João Sarmento Pimentel de 14 de Março (de 1951?)». O Ponto, 22 de Jan. 1981. (Comentada por Cecília Barreira. Contém ainda: «Carta de Nuno Simões a Sarmento Pimentel», de 19.8.1959, referindo a doença de Sérgio)

«Intervenção sergiana positiva em duas causas - uma defensável, detestável a outra» (Carta de A. S. a António Brotas comentada por Jacinto Baptista). O Ponto, 17 de Dez., 1981

«Carta inédita de António Sérgio a João Sarmento Pimentel, datada de 2 de Maio (de 1931), sobre a revolta da Madeira». O Ponto, 1 de Abr., 1982

«Cartas inéditas trocadas entre António Sérgio (2) e João Sarmento Pimentel (2) de 1953-54, com notícia do papel desempenhado pelo ensaísta na campanha eleitoral do Outono de 1953 e do caso da índia portuguesa». O Ponto, 27 de Maio, 1982

«Carta inédita de António Sérgio a Sarmento Pimentel, datada de 4 de Julho de 1954, na qual se trata da questão da índia Portuguesa». O Ponto, 3 de Jun., 1982

«Carta inédita de Bernardino Machado a Luisa Sérgio, de 17.12.931, em que se alude à protecção dispensada pela Igreja de Roma à ditadura militarista». O Ponto, 8 de Jul., 1982

«Duas cartas inéditas de Luisa Sérgio a Bernardino Machado de 18 de Julho de 1933 e de 19.12.1933» (a l. ${ }^{a}$ dá conta de uma detenção de A. S.). O Ponto, 15 de Jul., 1982

«Carta inédita de Bernardino Machado a Luisa Sérgio», datada de 
25.6.931, em que diz: «atravessamos um novo momento de confusão». O Ponto, 22 de Jul., 1982

«Observações de António Sérgio sobre um projecto de estatutos da União Geral dos Combatentes da República. Cópia da carta de 23 de Set. de 1932 espólio de Bernardino Machado e atribuída pelo prof. Machado Vaz ao ensaísta». O Ponto, 22 de Jul., 1982 «Carta inédita de Bernardino Machado a Luisa Sérgio, datada de 19.11.931, agradecendo um livro de Alves Correia que classifica como um dos mais notáveis documentes da mentalidade por-

v tuguesa dos últimos tempos». O Ponto, 5 de Ag., 1982

«Duas cartas inéditas de Bernardino Machado a Luisa Sérgio, datadas de 27 de Fev. de 1933 e de 16 de Set. de 1935, esta aludindo a um revoltante procedimento contra o ensaísta». O Ponto, 2 de Set., 1982

Baptista, Jacinto - «Sérgio uma vez mais. Carta inédita de António Sérgio a António Broxas, apresentada e comentada por Jacinto Baptista». O Ponto, n. ${ }^{\circ}$ 59, 17 de Dez., 1982

«Duas cartas inéditas para a história do regime ditactorial» (A Sarmento Rodrigues). Portugal Hoje, 9 de Out., 1979

Dionísio, Sant'Anna - «Lima obra de teatro clandestina e pouco conhecida de António Sergio» (c/ 4 missivas ae A. S.). O Primeiro de Janeiro, 30 de Aor., 1975

Dionísio, Sant'Anna- «Mais algumas cartas de António Sérgio». O Primeiro de Janeiro, 2 de Jul., 1975

Dionísio, bant'Anna - «uma carta impressiva e arisca de António Sérgio». O Primeiro de Janeiro, 28 de Jul., lyô2

Dionísio, Sant'Anna - «Arrazoado típico, epistolar e pedagógico de António Sérgio». O Primeiro ae Janeiro, 18 de Ag. Iyố2

Dionísio, Sant'Anna - «Ainda très missivas de António Sergio». O Primeiro de Janeiro, 10 de Nov., 1982

«Carta dirigida ao director da República respondendo ao artigo saído no Diário da Manhã pela pena do seu director, onde Sérgio é acusado do roubo de moedas de ouro na Biblioteca Nacional». Republic a, 16 de Jul., 1951

«Resposta às criticas que lhe foram feitas pelo Ministro do Interior, uma carta de António Sérgio». República, 25 de Out., 1953

«Carta de Sergio à redacção da República a propósito de um artigo saído num magazine brasileiro». República, 25 de Abr., 1959

Rego, Raul - «António Sergio e o Cardeal Cerejeira. Sou eu quem defende os interesses da Igreja — diz o ensaísta numa carta ao antigo Cardeal-Patriarca». (Carta de 23 de Nov. de 1956). República, 25 de Abr., 1980

Pedroso, Alberto - «Uma intervenção ignorada de António Sérgio». C/ carta inédita de A. S. a Alexandre Vieira). Seara Nova, n. ${ }^{\circ}$ 1596-7, Out.-Nov., 1978, 27-29 pp.

«Alguns documentos sobre a polémica entre António Sérgio e Bento de Jesus Caraça». (C/ 4 cartas de A. S.). Vértice, n. 394-95, Mar.-Abr., 1977, 209-214 pp.

Monteiro, Manuel - «Uma carta inédita de António Sérgio com um complemento directo de Manuel Monteiro». Vértice, n. ${ }^{\circ}$ 420-21, Maio-Jun., 1979, 194-199 pp.

«Carta escrita por António Sérgio a José Régio a propósito de Encruzilhadas de Deus». Vida Mundial, 25 de Set., 1970 
If ENTREVISTAS E INQUÉRITOS

\section{fl EM LIVROS}

Baptista, Jacinto - «A entrevista concedida por António Sérgio a $A$ Batalha (primeiro número)», Surgindo vem ao longe a nova aurora.... Para a história do diário sindicalista A Batalha. 1919-1927. Lisboa, ed. Bertrand, 1977, 177-181 pp.

\section{f2 EM PUBLICAÇÕES PERIÓDICAS}

Baptista, Jacinto - «Socialização sem estatismo. A sociedade visionada por António Sérgio». (Contém a resposta a um inquérito do Diário da Noite, datada de Paris, de Abr. de 1932, também publicada no n. ${ }^{\circ} 300$ da Seara Nova, mas, em ambos os casos, sem as perguntas que se publicam agora). Correio do Minho, 29 de Jan., 1983

«Em que trabalham os nossos escritores?». O Diabo, n. ${ }^{\circ} 149,2$ de Maio, 1937,5 p.

«A pena de morte» (Depoimento). O Diabo, n. ${ }^{\circ}$ 174, 23 de Jan., 1938, 1 p.

«Uma entrevista com António Sérgio». O Diabo, n. ${ }^{\circ}$ 279, 27 de Jan., 1940, 3-7 pp. (conduzida por Gentil Marques)

«Os democratas portugueses têm ideias precisas sobre os problemas administrativos da Nação». Diário de Lisboa, 12 de Out., 1945

«António Sérgio esboça uma crítica do corporativismo». Diário de Lisboa, 10 de Maio, 1958

«Uma entrevista de António Sérgio à Revista Portuguesa». Diário de Lisboa, 6 de Jan., 1981 (Revista Portuguesa, publicação semanal dirigida por Victor Falcão. Entrevista com a data de 28.7.1923)

«Inquérito entre os escritores: $O$ valor artístico das grandes obras literárias depende mais do modo de ser dos escritores do que das tendência ambientais, diz António Sérgio». Diário Popular, 15 de Fev., 1945

«Se não fosse a muralha dos preconceitos todos os verdadeiros amfgos do povo se poderiam entender». (Entrevista). Diário Popular, 31 de Out., 1953

Carvalho, Montezuma de - «Ouvindo expoentes da cultura e da Inteligência. Diálogo à distância com António Sérgio». Expoente, n. ${ }^{\circ}$ 59, ano VI, Out., 1957, S. Paulo, Brasil. (Publicado também em O Primeiro de Janeiro, de 6.1.1956)

«Um inquérito da Gazeta Musical. $O$ que pensam da música os nossos intelectuais. Responde António Sérgio». Gazeta Musical, n. ${ }^{\circ} 12$, 1 de Set., 1951, 5-7 pp.

«Respondem a um inquérito de Ler. António Sérgio». Ler, Jornal de Letras, Artes e Ciências, n. ${ }^{\circ} 18$, Set., 1953

«António Sérgio fala de Eça de Queiroz e Oliveira Martins». Primeiro de Janeiro, 27 de Set., 1944

Carvalho, Montezuma de - «Diálogo à distância com o pensador português António Sérgio». O Primeiro de Janeiro, 6 de Jan., 1956

«Um inquérito literário. António Sérgio diz que os intelectuais típicos da nossa terra se caracterizam pela incapacidade absoluta para 
o mais pequenino pensamento efectivo». República, 30 de Mar., 1943

«O dr. António Sérgio entrevistado pela República defende a mais completa liberdade individual e considera necessária a planificação económica». República, 10 de Jan. 1947

«António Sérgio fala à República sobre o movimento cooperativo português». República, 4 de Jun., 1948

«Entrevista com António Sérgio. Apresentação do programa submetido à discussão por um grupo de oposicionistas». República, 5 de Nov., 1953

«Tornar efectivos os direitos políticos do art. ${ }^{0} 8 .^{\circ}$ da Constituição, cumprir os princípios da ONU - fazer eleições honestas e criar um Conselho de Estudos Económico-Sociais são alguns dos aspectos da Reforma preconizada pelo ilustre pedagogista dr. António Sérgio, antigo ministro da Instrução, numa entrevista concedida à República». República, 30 de Jul., 1956

«Inquérito da República sobre eleições: Peço a todos que saiam da inércia, que se recenseiem sem demora e se preparem para ir às urnas, diz António Sérgio». República, 25 de Fev., 1957

«Resposta de Sérgio ao inquérito efectuado pelo República: Quais as características fundamentais do século passado e quais as características fundamentais do século actual até aos nossos dias?». República, 24 de Dez., 1958

«Factos e documentos». (Transcrição de uma entrevista dada ao Primeiro de Janeiro). Seara Nova, n. ${ }^{\circ}$ 500-3, 1 de Abr., 1937, 372-373 pp.

«Resposta a um inquérito promovido pelo Diário da Noite de 3 de Fev., 1932». Seara Nova, n. ${ }^{\circ} 300,26$ de Maio, 1932, 178, 190-1 pp.

«Iniciativas Patrióticas. A Liga de Acção Nacional». (Entrevista c/ o secretário geral da Liga e director do seu órgão na Imprensa, a revista Pela Grei). O Século, 8 de Mar., 1918

«António Sérgio responde ao novo Inquérito». Vértice, n. ${ }^{\circ} 30$ a 35 , (fase. 7), Maio de 1946, 158, 159, $161 \mathrm{pp}$.

«Sobre o problema da cultura. Diálogo com António Sérgio». (Complemento ao depoimento de A.S. publicado no Diário de Lisboa, de 30.5.1956). Vértice, n. ${ }^{\circ} 153$, Jun., 1956, 269-273 pp.

«Renovemos a Escola. António Sérgio fala à Voz da Justiça sobre o problema pedagógico». A Voz da Justiça, 19 de Jul., 1933

\section{f3 EM DISCO}

"Entrevista 4. António Sérgio». Entrevista recolhida por Igrejas Caeiro e transmitida por Rádio Club Português na rubrica «Perfil de um artista», em 27 de Jul., 1958. Lisboa, Gravações em disco Edições Sassetti, s/d 


\section{Ig TRADUÇÕES}

France, Anatole - A Vida em Flor. Paris, Casa Editorial Franco-Ibero-Americana, s. d. (1928?), 345 p.

Descartes, Renato - Meditações metafísicas. (Tradução e nota final). Coimbra Imprensa da Universidade, 1930. «Filósofos e Moralistas», $136 \mathrm{p}$.

Renouvier, Carlos - As últimas Conversações. (Tradução). Coimbra, Imprensa da Universidade, 1930. «Filósofos e Moralistas», 106 p.

Leibniz, G. W. - Novos ensaios sobre o entendimento humano. (Tradução). Coimbra, Imprensa da Universidade, 1931. «Filósofos e Moralistas», $155 \mathrm{p}$.

Sainte-Beuve - Retratos de mulheres. (Tradução). Coimbra, Imprensa da Universidade, $1932,86 \mathrm{p}$.

Munthe, Axel - Homem e bichos. (Trad, e prefácio). Lisboa, Editorial Progresso, s. d. (1937?), 253 p.

Kipling, Rudyard - Lobos do mar. (Tradução). Lisboa, Editorial Progresso, s. d. (1937?), 253 p.

Vários Autores. Galerias da Europa (Álbum das Galerias de Pintura dos Museus Alemães, Álbum do Museu do Louvre, Álbum dos Países Baixos e Álbum de Pintura Moderna). Tradução, Barcelona, Editorial Labor, s.d. (1938?), 4 vols.

Mc Taggart, John - Ellis - Introdução ao estudo da filosofia. (Tradução e prefácio). Lisboa, Editorial Inquérito, L.da, 1939. Cadernos «Inquérito», 2. ${ }^{a}$ ed.: Lisboa, Editorial Inquérito, L.da, s. d., Cadernos «Inquérito»

Russell, Bertrand - Os problemas da filosofia. (Tradução e prefácio). Coimbra, Arménio Amado, 1939. Colecção Studium, n. ${ }^{\circ} 16$, 216 p., 2. ${ }^{a}$ ed., 1941, com um PS, e notas finais de A. Sérgio

Rousseau, J. J. - Emílio. (Excertos seleccionados, traduzidos, anotados e prefaciados). Lisboa, Editorial Inquérito, L.da, 1940, 2 vols. Cadernos «Inquérito»

Thomson, J. Arthur - Introdução à ciência. (Tradução e nota final).

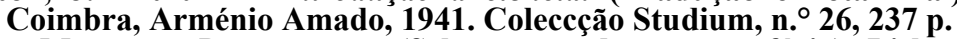

Aurélio, Marco - Pensamentos. (Selecção, tradução e prefácio). Lisboa, Edições Ática, 1947, 75 p.

Berkeley, George - Três diálogos entre Hilas e Filonous em oposição aos cépticos $e$ ateus. (Tradução, prefácio e notas). Coimbra. Atlântida Editora, 1948. «Biblioteca Filosófica», 4, 185 p. 2a ed.: Coimbra, Atlântida Editora, 1965, «Biblioteca Filosófica», 4

Tolstoi, Leão - Khadji Murat - O Diabo Branco. (Tradução indirecta c/ prefácio). Rio de Janeiro, Civilização Brasileira, 1934, 193 p.

Tolstoi, Leão - O demónio branco. (Tradução indirecta e prefácio). Lisboa, Editora Arcádia, L.da, s. d. (1958?). «Colecção Autores Estrangeiros», 161 p.

\section{Ih REPRESENTAÇÃO EM ANTOLOGIAS}

Campos, Agostinho de - Paladinos da Linguagem, II vol., Lisboa, Livr. Aillaud e Bertrand, 1922, 262 p. (António Sérgio, pp. 117-125)

Costa, Fernando Ferreira da - Doutrinários Cooperativistas Portugueses. Subsídios para o estudo do sector cooperativo português. 
Lisboa, Horizonte Universitário, 1978, 468 p. (António Sérgio, pp. 297 a 408)

Machado, Augusto Heis - Antologia Histórico-Sociológica. Lisboa, O Tempo e o Modo, edit. Morais, 1964, 125 p. (António Sérgio, pp. 91-í22)

Marques, A. H. de Oliveira - Antologia da Historiografia Portuguesa, 2 vol., Lisboa, Publicacões Europa-América, 1. ${ }^{\circ}$ vol., l. ${ }^{\mathrm{a}}$ ed. 1974, 2. ${ }^{\circ}$ vol. l. $^{\mathrm{a}}$ ed. 1975 . (C/ referências a A. S. na introdução do l. vol. No $2 .^{\circ}$ vol. contém: «António Sérgio» pp. 158-170, nota biográfica e textos de: Introdução Geográfica à História de Portugal, Sobre a Revolução de 1383-85, A Conquista de Ceuta, Interpretação não romântica do Sebastianismo, $O$ Reino Cadaveroso)

Pires, António Machado - D. Sebastião o Encoberto. Lisboa, ed. Fundação Gulbenkian, 1982, $453 \mathrm{p}$. (c/ antologia de textos sobre D. Sebastião. António Sérgio: 396-406 pp.)

Quadros, António - A Tese da História em Portugal (I vol. O conceito de História; II vol. A dinâmica da História). Excertos dos Ensaios. Lisboa, Col. Biblioteca de Cultura Portuguesa, ed. Espiral, s. d. (1968?) I vol. pp. 53-55, 96-97. II vol. pp. 153-158

Serrão, Joel - Iniciação ao filosofar (c/ o texto de A. S. «Reflexão é o pensamento sobre o próprio pensamento» das Cartas de Problemática, n. ${ }^{\circ}$, pp. 173-183. Lisboa, Livr. Sá da Costa, 1970

Serrão, Joel e Jorge Macedo - Introdução à Filosofia e Psicologia. Lisboa, Livr. Sá da Costa, 1.a ed., 1948, 8a ed., 1971. (De A. S.: «Do nível sensorial ao nível formal ou científico», 6-9 pp.)

Serrão, Joel e Rui Grácio - Filosofia, Antologia. Lisboa, Livr. Sá da Costa, $1 .{ }^{\mathrm{a}}$ ed. 1966, 5 a ed. 1972. (De A. S.: «A creatividade do intelecto», 144-145 pp.; «Idealismo e verdade», 160-161 pp.)

Serrão, Joel - Prosa doutrinal de autores portugueses. Segunda Série. António Sérgio. Col. Antologias Universais, Lisboa, Portugália, s/d (1967), 553 p. (e/ o prefácio: «Breve introdução ao ensaísmo sergiano» e os textos seguintes: Sobre educação primária e infantil; prefácio a Os Problemas da Filosofia de Bertrand Russell; Cartas de Problemática n. ${ }^{\circ}$ 9; Divagações proemiais ao jovem leitor sobre a actividade mental que presidiu a este ensaio in: Introdução Geográfico-Sociológica à História de Portugal; Os «Espectros» Históricos, Ensaios I; As duas políticas nacionais, Ensaios II; $A$ conquista de Ceuta, Ensaios I; $O$ povo dos nossos campos, Introdução Geográfico-Sociológica à História de Portugal; $O$ reino cadaveroso ou o problema da cultura em Portugal, Ensaios II; Educação de autónomos pela autonomia, Cartas do Terceiro Homem; o Self-Government e a escola, Educação Cívica; Paideía, Ensaios VII; $A$ propósito dos Ensaios Políticos de Spencer, Ensaios II; Democracia; Alocução aos Socialistas; E porque não hão-de as obras nascer já humanas?, Cartas do Terceiro Homem; Questão prévia dum ignorante aos prefaciadores da Lírica de Camões, Ensaios IV; Nótula sobre Nicolau Tolentino, Ensaios $V$; Os dois Anteros (o luminoso e o nocturno), Ensaios IV; Cristianismo ideal e cristianismo real, Ensaios IV; Em torno da expressão Civilização Cristã, Ensaios VI; Que empreenderia agora um S. Francisco de Assis, que faria agora um S. Vicente de Paulo?, Cartas do Terceiro Homem; Migalhas de filosofia, Ensaios VII; Quando se passa do físico para a actividade vital, Cartas de Problemática; Deus como ideia na cons- 
ciência do homem, Cartas de Problemática; $A$ radical espontaneidade criadora do intelecto, Prefácio a Três Diálogos entre Hilas e Filonous de Berkeley

Serrão, Joel - Antologia do Pensamento Político Português, 1. Liberalismo, socialismo, republicanismo. Selecção, introdução e notas de Joel Serrão. Porto, ed. Inova, 1970. (De A. S.: «O remédio para os erros de liberdade é uma liberdade mais bem entendida", 389-407 pp., publicado no tomo II dos Ensaios sob o titulo: "A propósito dos Ensaios Políticos de Spencer e publicado em A Águia, Jun. de 1917)

Tengarrinha, José - Tentativa de interpretação da História de Portugal. (C/ prefácio do autor e dois ensaios: o que intitula a obra e «Importância do factor económico na interpretação da História». $\mathrm{O} 10^{\circ}$ é o prefácio à Introdução Geográfica à História de Portugal; o $2 .^{\circ}$ é o prefácio à Antologia dos hiconomistas Portugueses) col. Tempo de ensaio, n. ${ }^{\circ}$, Lisboa, ed. Tempo, s. d. (1962?), $40 \mathrm{p}$.

\section{BIBLIOGRAFIA PASSIVA}

\section{lia ESTUDOS EXCLUSIVOS SOBRE A OBRA}

Abreu, Eng. José de - Rescaldo da Revista "Camiliana \& Vária». Lisboa, Separata do Boletim Mensal da Sociedade de Língua Portuguesa, 1968, 11 p. (Sobre o artigo de A. S. «Monólogo do vaqueiro ou notazinha problemática sobre 0 Amor de Perdição, publicado na revista Camiliana \& Vária)

Carvalho, Montezuma de - António Sérgio a obra e o homem. Lisboa, ed. Arcádia, 1979, 491 p.

Dionísio, Sant'Anna- Objecções a António Sérgio sobre o valor da obra filosófica de Leonardo Coimbra. Porto, s/ ed., 1938, 115 p.

Dória, A. Álvaro - António Sérgio um educador do povo português. Braga, s/ ed., 1969, 5 p.

Fernandes, Henrique J. de Barahona - «Da Psicologia para a Epistemologia - o humanismo criativo de António Sérgio», in: Homenagem a António Sérgio, Lisboa, Academia das Ciências de Lisboa, Instituto de Altos Estudos, 1976, 71-122 pp.

Ferreira, David Mourão - «Situação de António Sérgio na História da Crítica Literária», in: Homenagem a António Sérgio. Lisboa, Academia das Ciências de Lisboa, Instituto de Altos Estudos, 1976, 53-70 pp.

Lima, Pedro Manuel de Almeida - «Palavras de abertura no ciclo de conferências em homenagem a António Sérgio», in: Homenagem a António Sérgio. Lisboa, Academia das Ciências de Lisboa, Instituto de Altos Estudos, 1976, 9-11 pp.

Medina, João__ O Pelicano e a Seara, a Revista "Homens Livres». Lisboa, ed. António Ramos, s/d (1979), 133 p. (Reedição integral dos dois únicos números desta revista dirigida por $\mathrm{A}$. S., c/ notas de interesse sobre a sua participação num grupo onde se reúnem integralistas e seareiros)

Pacheco, J. Preto $-A$ História Sergista de Portugal. Lisboa, s/ed., 1941, 127 p. 
Pimenta, Alfredo - A História de Portugal do Sr. António Sérgio vista por Alfredo Pimenta. Lisboa, ed. do autor, 1941, 46 p.

Sá, Victor de - A historiografia Sociológica de António Sérgio. Lisboa, Col. Biblioteca Breve n. ${ }^{\circ}$ 34, Instituto de Cultura Portuguesa, 1979, 112 p.

Saraiva, António José - O Caprichismo Polémico do sr. António Sérgio. Porto, ed. do autor, 1952, 55 p.

Serrão, Joel - «Breve Introdução ao Ensaísmo Sergiano», Prosa Doutrinal de Autores Portugueses, Segunda Série, António Sérgio. Col. Antologias Universais, Lisboa, Portugália, s/d (1967), 11 a 50 pp.

Serrão, Joel - «O lugar da História no pensamento de António Sérgio», in: Homenagem a António Sérgio. Lisboa, Academia das Ciências de Lisboa, Instituto de Altos Estudos, 1976, 45-52 pp.

Silveira, António de - «Recordando António Sérgio - com forçados excertos autobiográficos e diversos comentảrios inactuais», in: Homenagem a António Sérgio. Lisboa, Academia das Ciências de Lisboa, Instituto de Altos Estudos, 1976, 13-37 pp.

Tengarrinha, José - Prefácio a Tentativa de Interpretação da História de Portugal. Lisboa, Col. Tempo de Ensaio n. ${ }^{\circ}$ 6, ed. Tempo, s/d (1962?), 5-7 pp.

Vilhena, Henrique J. de - «Relatório a pronunciar devidamente em prol da entrada do muito notável escritor senhor dr. António Sérgio de Sousa na classe de ciências da Academia das Ciências de Lisboa", in: Homenagem a António Sérgio. Lisboa, Academia das Ciências de Lisboa, Instituto de Altos Estudos, 1976, 39-43 pp.

Vilhena, V. de Magalhães - António Sérgio e a Filosofia. Lisboa, ed. Cosmos, $1960,30 \mathrm{p}$.

Vilhena, V. de Magalhães - António Sérgio o idealismo crítico e a crise da ideologia burguesa. Lisboa, Col. Argumentos, n. ${ }^{\circ}$, Seara Nova, 1964, 197 p. 2. a ed. Lisboa, ed. Cosmos, (reimpressão da l.a ed.)

Vilhena, P. de Magalhães - «Em torno da génese do idealismo filosófico de António Sérgio», in: Homenagem a António Sérgio. Lisboa, Academia de Ciências de Lisboa, Instituto de Altos Estudos, 1976, 123-145 pp.

\section{Ilb PUBLICAÇÕES COM ESTUDOS OU REFERÊNCIAS SOBRE A OBRA}

Almeida, Henrique - O Clube Fenianos Portuense na Oposição ao Fascismo na década de 40. Porto, 1982, 51 p. (Contém ref.as a A. S. e largos trechos de «Antero de Quental e António Vieira perante a civilização cristã», etc.)

Antunes, José Freire - A Cadeira de Sidónio ou a Memória do Presidencialismo. Lisboa, ed. Europa-América, 1981, 192 p. (C/ ref. ${ }^{\text {as }}$ de interesse a A.S.)

Baptista, Jacinto - Surgindo vem ao Longe a Nova Aurora... Para a história do diário sindicalista "A Batalha" 1919-1927. Lisboa, Bertrand, 1977, 214 p. (De grande interesse para as relações entre sindicalistas e seareiros. Transcreve a entrevista dada por A. S. ao $1 .^{\circ}$ n. ${ }^{\circ}$ de «A Batalha») 


\section{Antonio Sérgio}

Barbosa, Manuel-«Presença de António Sérgio». Figuras \& Perfis Literários, Ribeira Grande, ed. do autor, 1983, 209-218 pp.

Barreira, Cecilia - «O ideário Seareiro. Alguns apontamentos para uma polémica (1921-1926)». Sondagens em torno da Cultura $e$ das ideologias em Portugal (secs. $X i X-X X$ ). Col. Temas Portugueses, n. ${ }^{\circ}$, Lisboa, ed. Polemos, 1983, 101-119 p.

Barreira, Cecília - «A Renascença Portuguesa. Sérgio, Pascoaes e a Renascença Portuguesa». Sondagens em torno da Cultura e das Ideologias em Portugal (secs. $X I X-X X$ ). Col. Temas Portugueses, n. ${ }^{\circ}$, Lisboa, ed. Polemos, 1983, 59-65 pp.

Barreira, Cecília - «Sérgio, Cortesão e A Vida Portuguesa». Sondagens em torno da Cultura e das Ideologias em Portugal (sécs. $X I X-X X)$. Col. Temas Portugueses, n. ${ }^{\circ}$, Lisboa, ed. Polemos, 1983, 66-73 pp.

Branco, João de Freitas - Viana da Mota, Lisboa, ed. Fundação Gulbenkian, 1972, 451 p. (além do prefácio da autoria de A. S., contém reí. as de interesse ao ensaísta)

Botelho, Afonso - Origem e Actualidade do Civismo. Lisboa, ed. Terra Livre, Direc. Geral de Divuigaçao, 1979, 144 p. (c/ reí. ${ }^{a s}$ de interesse a A. S.)

Caetano, Marcelo - Minhas memórias de Salazar, Lisboa, ed. Verbo, 1977 (c/ ref.as a A. S. 30, 365, 469 pp.)

Caraça, Bento de Jesus - «Resposta a uma crítica»; "Carta a António Sérgio crítico»; «Nota em guisa de conclusão». Conferências $e$ outros Escritos. Lisboa, s/ed., 1970, 289-320 pp. (Em apêndice «Nota a um passo de uma introdução a Berkeley» de A. S., que originou a «Resposta a uma crítica»; «Réplica sem severidade a um severo Amigo» de A. S. e «Explicações para os que entendem a linguagem que eu falo» de A. S.)

Carrilho, Manuel Maria - «Sérgio e a Filosofia», in: Filosofia e Epistemologia II. Lisboa, ed. A Regra do Jogo, 1979, 59-100 pp.

Carrilho, Manuel Maria - «Ensaísmo e filosofia: António Sérgio». O Saber e o Método, Lisboa, Imprensa Nacional - Casa da Moeda, 1982, 58 a 104 pp. (Segundo uma nota, este estudo retoma com alterações 0 artigo anterior)

Carvalho, Joaquim Barradas de - «António Sérgio». O Obscurantismo Salazarista. Lisboa, ed. Seara Nova, 1974, 121-125 pp.

Chaves, Castelo Branco - «António Sérgio e a sua primeira polémica». Crítica Inactual. Lisboa, ed. Arcádia, 1981, 163-171 pp. (Publicado pela $1 .{ }^{a}$ vez em $A$ Capital, a 9 e 23.5.1969)

Cidade, Hernani - «António Sérgio». Portugal Histórico Cultural. Lisboa, ed. Círculo de Leitores, 1973, 397-411 pp.

Comissão do livro negro sobre o regime fascista - Livros Proibidos no regime fascista. (Contém ref. ${ }^{a}$ a duas obras de A. S. proibidas: Educação Cívica e História de Portugal, 83 p.). Lisboa, Presidência do Conselho de Ministros, 1981, 124 p.

Correia, Joaquim Alves - Cristianismo e Revolução. (C/ ref.as a A. S. no prefácio e introdução e um extracto dos Diálogos de Doutina Democrática). Lisboa, Liv. Sá da Costa, 1977, 227-229 pp.

Costa, Fernando Ferreira da - Doutrinadores Cooperativistas Portugueses, Lisboa, ed. Livros Horizonte, Nov. 1978, 468 pp.

Costa, Fernando Ferreira da - O Pensamento Cooperativo de António Sérgio $e$ as correntes cooperativas francesas. Col. estudos cooperativos - 1, Viseu, ed. Centro de Estudos Cooperativos de Viseu, 1983, 9-32 pp.

Cunhal, Álvaro - As Lutas de Classes em Portugal nos Fins da Idade Média. Col. Teoria, n. ${ }^{\circ}$ 27, Lisboa, ed. Estampa, 1975, 135 p. (C/ 
alusões críticas ao prefácio à Crónica de D. João $I$ de Fernão Lopes)

Fernandes, H. J. Barahona - «As estruturas do intelecto segundo as Cartas de Problemática de António Sérgio», in: Memórias da Academia das Ciências de Lisboa - Classe de Ciências. Tomo XIII. Lisboa, Academia das Ciências de Lisboa, 1968, 149-174 pp.

Fernandes, Rogério - O Pensamento Pedagógico em Portugal. Gol. Biblioteca Breve, $\mathbf{n} .^{\circ}$ 20, Lisboa, Instituto de Cultura Portuguesa,

1978, 144 p. (C/ ref.as de interesse a A. S. Uma nota de pé de página no final do livro anuncia a publicação de uma obra, na mesma col. dedicada ao pensamento pedagógico de A.S.)

Fernandes, Rogério - «António Sérgio: Uma pedagogia para o ressurgimento nacional». A pedagogia portuguesa contemporânea. Biblioteca Breve, n. ${ }^{\circ}$ 37, Lisboa, Instituto de Cultura Portuguesa, 1979, 43-110 pp.

Ferreira, David Mourão - «António Sérgio crítico literário». Motim Literário. Lisboa, ed. Verbo, 1962, 38-64 pp.

Fey, Éduard - «António Sérgio (1883-1969)». O ensino da Filosofia em Portugal, Lisboa, 1978, 68-69 pp. (artigo publicado na Brotéria, vol. $107,{ }^{\circ} 1$ a 5,1978 )

Freyre, Gilberto - Aventura e Rotina, Lisboa, Livros do Brasil, Ld.a, s/d. (1952?) $453 \mathrm{p}$. (c/ ref. ${ }^{\text {as }}$ de interesse a A. S.)

Godinho, Vitorino Magalhães - Ensaios. Sobre História Universal I. Lisboa, ed. Sá da Costa, 1968, 289 p. (c/ particular referência a A. S. no prefácio)

Godinho, Vitorino Magalhães - «Ao investigador cabe enfrentar os grandes problemas nacionais em inteira isenção e não ao serviço de conveniências». (Entrevista conduzida por António Borges Coelho). Seara Nova, n. ${ }^{\circ} 1480$, Fev. 1969. C/ uma resposta onde se foca 0 magistério sergiano e a reforma da mentalidade)

Godinho, Vitorino Magalhães - «António Sérgio: o Portugal que somos e o Portugal que queremos ser»; «Excertos de António Sérgio» (1. Reforma da mentalidade 2. Como foi pensada, e para quê, a Breve Interpretação da História de Portugal 3. Os problemas de Portugal 4. Política de transporte e política de fixação 5. A prioridade da agricultura para o arranque do desenvolvimento). Para a renovação da política nacional. Lisboa, Livr. Sá da Costa, 1978, 91-108 pp.

Grácio, Rui - "António Sérgio» Educação e Educadores. Biblioteca da Educação Profissional. Lisboa, ed. Livros Horizonte, s/d (1968), 165-177 pp. (C/ breve análise do pensamento pedagógico de A. S.)

Lapa, Rodrigues - «António Sérgio e o problema da língua literária». Estudos Galego-Portugueses. Lisboa, Livr. Sá da Costa, 1979, 117-129 pp.

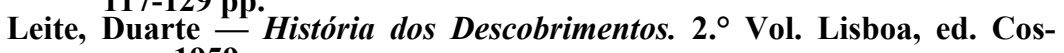
mos, 1959

Leite, João Salazar - «O sector cooperativo em Fauquet, em António Sérgio e na Constituição da República Portuguesa». Cooperação $\boldsymbol{e}$ Intercooperação, Col. Formação Cooperativa, n. ${ }^{\circ}$, ed. Livros Horizonte, 1982, 28-31 pp.

Lima, Sílvio - Ensaio sobre a Essência do Ensaio. Col. Studium, n. ${ }^{\circ} 41$, Coimbra, ed. Arménio Amado, 1944. (2.a ed. 1964), 203 p. (C/ um estudo sobre o carácter do ensaísmo sergiano, sendo considerada por A. S. "a obra mais lúcida e de mais acerto acerca da natureza da literatura ensaística» no prefácio a: Prosa Doutrinal de Autores Portugueses) 
Lins, Álvaro - Missão em Portugal (1.ำ vol.) Rio de Janeiro, ed. Civilização Brasileira S. A., 1960. (C/ ref.as de interesse a A. S. e transcrição de um documento político assinado pelo ensaista (11.11.1958) sobre a vinda de Aneurim Bevan a Portugal)

Lopes, Fernando Farelo - «A aposta perdida de Pela Grei: o Tecno-liberalismo Nacional perante o sidonismo». (Comunicação apresentada ao colóquio - A Formação de Portugal Contemporâneo: 1960-1980, organizado pelo GIS (Gabinete de Investigações Sociais). Lisboa, Dez. 1981, publicado sob o título: $A$ revista «Pela Grei» (doutrina e prática políticas) in: Análise Social, n. ${ }^{\circ}$ 72-73-74, Abr.-Dez, 1982, 759-772 pp.

Lopes, Fernando Farelo - «O liberalismo decadente da Seara Nova (Algumas hipóteses)». O Fascismo em Portugal. Actas do colóquio realizado na Faculdade de Letras de Lisboa em Março de 1980. Lisboa, ed. A Regra do Jogo, 1982, 141-165 pp.

Lopes, Fernando Farelo - «Liberalismo e rendição: a Seara Nova, 1921-27». (Comunicação apresentada no seminário: O Fascismo $e$ o seu advento em Portugal, realizado em Maio de 1981, pelo GIS (Gabinete de Investigações Sociais), Lisboa, Dez. 1981

Lopes, óscar - «Ensaios VIII»; "Sérgio visto por Magalhães Vilhena»; "A crítica literária nos Ensaios». Ler e Depois. Porto, ed. Inova, 1969, 211-235 pp.

Lopes, óscar - História Ilustrada das Grandes Literaturas, Literatura Portuguesa. II vol. Lisboa, ed. Estúdios Cor, 1973, 915 p. (C/ inúmeras referências e uma importante notícia crítica sobre o pensamento de A. S., 479-488 pp.)

Lourenço, Eduardo - «Sérgio como mito cultural. É o autor de Ensaios um ensaísta?». O Labirinto da Saudade. Lisboa, Public. D. Quixote, 1978, 175-191 pp.

Marinho, José - Verdade, Condição e Destino no pensamento português contemporâneo. Porto, ed. Lello \& Irmão, 1976, 311 p. (com ref. $^{35}$ de grande interesse ao pensamento filosófico de A. S. especialmente entre 200 e 213 pp.)

Marques, A. H. de Oliveira - A Liga de Paris e a Ditadura Militar. 1927-1928. A questão do empréstimo externo. Col. Estudos e documentos. Lisboa, Public. Europa-América, 1978, 298 p. (De A. S.: «Carta aberta aos oficiais portugueses que ainda admitem a ditadura», 136-148 pp; «Para a preparação do após-ditadura», 148-157 pp. e outros documentos de colaboração)

Nogueira, Jofre Amaral - «Carta ao sr. António Sérgio e comentário para compreender». Um Humanismo à Nossa Medida. Porto, ed. Inova, 1971, 351-364 pp. (Publicado pela l.a vez em Sol Nascente, n. ${ }^{\circ} 19$ e n. $\left.{ }^{\circ} 21,1937\right)$

Pimentel, Sarmento - Memórias do Capitão, col. Ofício de Viver, n. ${ }^{\circ}$ 20, Porto, ed. Inova, 450 p., 2. ${ }^{\text {a }}$ ed. 1974 (c/ ref. ${ }^{\text {as }}$ de interesse a A. S.)

Pimentel, Sarmento - Sarmento Pimentel ou uma geração traída, Diálogos de Norberto Lopes com o autor das Memórias do Capitão, Lisboa, ed. Aster, 1976, 133 p. (c/ ref.as de interesse a A. S.)

Pinto, Álvaro - «Para a história da Aguia $e$ da Renascença Portuguesa». Ocidente, n. ${ }^{\circ}$ 1, vol. I, Maio de 1938, 137-151 pp. (c/ continuação nos n.os 2,4 e 6)

Pinto, Jaime Nogueira - «Polémicas de António Sérgio. Questão Sebástica, $O$ Seiscentismo, Idealismo e Realismo", in: As Grandes Polémicas Portuguesas. Lisboa, ed. Verbo, II vol., 1967, 439$-441 \mathrm{pp}$. 


\section{Bibliografia de António Sérgio}

Pires, António Machado - D. Sebastião o Encoberto. Lisboa, ed. Fundação Gulbenkian, 1982, $453 \mathrm{pp}$. (C/ antologia de textos sobre D. Sebastião. António Sérgio, 396-406 pp.)

Régio, José - «António Sérgio e o Sol Nascente». Páginas de Doutrina e Crítica da «Presença». Porto, Brasilia Editora, 1977, 326-327 pp. (Publicado no n. ${ }^{\circ} 51$ da Presença. Março de 1938. Refere-se à polémica de A. S. c/ o prof. Abel Salazar)

Regio, José - «Discurso sobre Camões».Ensaios de Interpretação Crítica. Lisboa, Portugália Editora, 1964, 253 p. (C/ referências de interesse sobre os ensaios camonianos de A. S.)

Ribeiro, Orlando - «Em torno de António Sérgio. Do ensaio à geografia». Introduções Geográficas à História de Portugal. Estudo crítico. Lisboa, Imprensa Nacional, Casa da Moeda, 1977, 119-181 pp. (Estudo crítico sobre o $1 .^{\circ}$ vol. da História de Portugal de A. S., depois reeditado c/ o título Introdução Geográfica e Sociológica à História de Portugal)

Sá, Victor de - «António Sérgio». Esboço Histórico das Ciências Sociais em Portugal. Col. Biblioteca Breve, n. ${ }^{\circ} 17$, Lisboa, Secretaria de Estado da Cultura, 1978, 95-99 pp.

Sá, Victor de - «A questão colonial na obra de António Sérgio». No Mar do Futuro. Lisboa, Livros Horizonte, 1980, 13-29 pp.

Sá, Victor de - «Perspectivas para uma compreensão da Segunda República». No Mar do Futuro. Lisboa, ed. Livros Horizonte, $1980,51$ a $66 \mathrm{pp}$. (C/ referências de interesse a $A . S$. $)$

Sá, Victor de - «Mouzinho, António Sérgio e a Teoria das Duas Políticas Nacionais». Época Contemporânea Portuguesa I. Lisboa, ed. Livros Horizonte, 1981, 115-120 pp.

Saraiva, António José - Para a História da Cultura em Portugal. Vol I. Lisboa, ed. Bertrand, 1980, 259 p. (Prólogo da 3.a ed. c/ interesse sergiano)

Sena, Jorge de - Trinta Anos de Camões. II vol. Lisboa, ed. 70, 1980, 279 p. (C/ referências aos ensaios camonianos de A. S.)

Serrão, Joaquim Veríssimo - A Historiografia Portuguesa. Lisboa, ed. Verbo, vol. III, séc. XVIII. (C/ referências a A. S. no capítulo: "Os estrangeirados e o labor da História», 20 p.)

Serrão, Joel - «Para uma interpretação do ensaísmo histórico-pedagógico de António Sérgio». Temas de Cultura Portuguesa, Lisboa, ed. Ática, 1960, 169-184 pp.

Serrão, Joel - «Para uma apologia de António Sérgio, I A Dialéctica dos Fins e dos Meios. II O Meio por Excelência - a Educação». Portugueses Somos, Lisboa, ed. Livros Horizonte, s/d., 75 a 119 pp.

Simões, João Gaspar - «Crítica Pedagógica - António Sérgio». Crítica I, a prosa e o romance contemporâneos. Porto, Livr. Latina, 1942, 59-62 pp. (Sobre o ensaísmo literário de A. S.).

Simões, João Gaspar- «António Sérgio». Crítica V, críticos e ensaístas contemporâneos (1942-1970). Lisboa, Imprensa Nacional-Casa da Moeda, 1983, 705-712 pp.

Valente, Vasco Pulido - O Estado Liberal e o Ensino. Os Liceus Portugueses (1834-1930). Lisboa, Col. Cadernos Gis, n. ${ }^{\circ}$ 5, Gabinete de Investigações Sociais, 1973, 163 p. (c/ ref/* de interesse a A. S.) 


\section{Ile ARTIGOS, EM PUBLICACÕES PERIÓDICAS, COM ESTUDOS OU REFERENCIAS SOBRE A OBRA}

\section{cl NÃO ASSINADOS}

«Tópicos do ideário sergiano». A Capital, 26 de Mar., 1969

«A primeira lição de António Sérgio nos Estudos Sociais Económicos e Literários. O Diabo, n. ${ }^{\circ} 33,10$ de Fev., 1935, 6 p. (Resumo da conferência «A influência da Grécia na civilização europeia»)

«António Sérgio escreveu para as crianças portuguesas». Diário de Lisboa, 14 de Abr., 1979

«Transcrição dos Conselheiros do Califa». Diário de Lisboa, 5 de Maio, 1979

«Eles bem mereciam.... mas assim não (sobre a reintegração na função pública». Diário de Lisboa, 24 de Jul., 1980

"Cartas do Terceiro Homem" (ref. à obra saída a lume. Diário de Lisboa, 27 de Set., 1955

Ref. à à publicação do caderno de A. S. Sobre o espírito do Cooperativismo. Diário de Lisboa, 6 de Nov., 1958

«Foram postos em liberdade os 4 indivíduos presos há dias (Sérgio, Cortesão e outros)». Diário de Lisboa, 29 de Nov., 1958

«A estatura intelectual de António Sérgio». Diário de Lisboa, 12 de Set., 1962

«Lusitanos e romanos, ensaio inédito de António Sérgio». Diário de Lisboa, 16 de Out., 1958

«Um estudo do pensamento filosófico e crítico de António Sérgio pelo Prof. Magalhães Vilhena». Diário de Lisboa, 11 de Mar., 1965

«António Sérgio o intelectual e o cidadão indomável». Diário de Lisboa, 25 de Jan., 1969

«Homenagem em Lourenço Marques à memória de António Sérgio». Diário de Lisboa, 28 de Jan., 1969

Ref. a a um n. ${ }^{Q}$ especial consagrado a António Sérgio, no Tempo e o Modo. Diário de Lisboa, 21 de Jul., 1969

«Nome de uma rua em Moçambique». Diário de Lisboa, 21 de Jun., 1974

«Sérgio e Cunhal editados em Cuba». Diário de Lisboa, 22 de Jun., 1974

"António Sérgio evocado no instituto com o seu nome» (ref.a a palestras de A. S. na rádio a partir de 1948). Diário de Lisboa, 25 de Jan., 1979

«Para a História do Cooperativismo: advertência de António Sérgio». Diário Popular, 8 de Out., 1982

«António Sérgio e a sua influência mental nos homens de hoje». Jornal do Comércio, 7-8 de Set., 1963

«Raízes da Social Democracia na obra de António Sérgio». Povo Livre, 24 de Set., 1974

«Reedições. Ensaios (tomo I), de António Sérgio». O Primeiro de Janeiro, Suplemento das artes, das letras, 14 de Dez., 1949

«António Sérgio profere conferências nos festejos da Cooperativa Sacavenense por ocasião do $48 .^{\circ}$ ano». República, 21 de Jul., 1948

«António Sérgio e Rodrigues Lapa vão falar numa sessão promovida pelas freguesias do 3. ${ }^{\circ}$ Bairro, na Voz do Operário». República, 1 de Fev., 1949

«António Sérgio falou nas festas de encerramento do $50 .^{\circ}$ aniversário da Cooperativa de Crédito e Consumo A Sacavenense. República, 15 de Ag., 1950 
«Um livro oportuno» (ref.a às Cartas do Terceiro Homem). República. 3 de Dez., 1953

Ref. a ao artigo de Lins do Rego no «Jornal» do Rio de Janeiro sobre as Cartas do Terceiro Homem. República, 19 de Jan., 1954

«No Instituto Britânico Sérgio proferirá uma conferência sobre o almirante inglês de Portugal, Napier, realizar-se-á a 18 de Maio». República, 14 de Maio, 1954

Alusão ao artigo de Olivio Montenegro que teria referido as Cartas do Terceiro Homem, no «Jornal» do Rio de Janeiro a 1.5.1954. República, 20 de Maio, 1954

«Na sessẫo evocativa do centenário de Garrett, Sérgio preside e toma a palavra» (em Leiria). República, 16 de Dez., 1954

Refere a alocução que Sérgio proferirá na Cooperativa Trabalhadores de Portugal. República, 14 de Maio, 1955

«Palavras de António Sérgio na homenagem de Julião Quintinha na Sociedade de Belas Artes». República, 15 de Jun., 1956

«Sérgio presidirá à sessão do 31 de Janeiro no Porto, no Coliseu e proferirá uma alocução». República, 25 de Jan., 1957

«Alocução no encerramento da sessão de 31.1». República, 6 de Fev., 1957

«Sérgio prefacia O Movimento Cooperativo Britânico de F. Ferreira da Costa. República, 22 de Fev., 1957

«A comissão promotora do voto dirige-se ao Sr. Ministro do Interior».

«O Ministro do Interior responde ao sr. dr. António Sérgio». República, 7 de Maio, 1957

«Publica-se a 3.a série das Cartas do Terceiro Homem». República, 15 de Dez., 1957

«Sérgio e outros intelectuais são detidos. Processo instaurado no Subsecretariado de Estado da Aeronáutica». República, 26 de Nov., 1958

«Postos em Liberdade». República, 29 de Nov., 1958

«Homenagem comemorativa dos 50 anos do escritor» (c/ uma caricatura). República, 22 de Fev., 1959

«Sérgio melhora». República, 5 de Maio, 1959

«A revista Manchete transcreve a resposta de Sérgio» (vide República de 25-4-959). República, 15 de Jun., 1959

«Uma justa reparação a António Sérgio. Recebe 50 mil escudos da Labor, afirma V. Soromenho seu advogado». República, 19 de Jun., 1959

«Breve antologia de Sérgio; contributo a uma cronologia de António Sérgio; homenagem a um Contemporâneo do Futuro». República, 4 de Fev., 1969

"A Seara Nova e A Batalha» (sobre o ataque que o jornal sindicalista $A$ Batalha dirigiu a A. S.). Seara Nova, n. ${ }^{\circ} 2,20$ de Jan., 1924, 114 p.

«A Batalha e a Seara Nova» (sobre o ataque dirigido a A. S. pelo jornal sindicalista A Batalha). Seara Nova, n. ${ }^{\circ} 31,15$ de Fev., 1924,133 p.

«António Sérgio» (sobre a morte do escritor). Seara Nova, aditamento ao n. 1480 , Fev., 1969

«Para a História do Movimento Operário português. Uma intervenção ignorada de António Sérgio». Seara Nova, n. ${ }^{\circ}$ 1596/97, Out.Nov., 1978

«A atitude do Sol Nascente perante um conflito» (sobre a polémica Abel Salazar - António Sérgio). Sol Nascente, 15 de Jan., 1938, 4 p. 
«O sr. dr. Antonio Sérgio falou....» (nota sobre a entrevista de A. S. a O Diabo de 27.1.1940). Sol Nascente, $n .^{\circ} 43-44$, Mar., 1940, 3 p.

«Antonio Sérgio teye para uma das suas obras um colaborador brilhantíssimo e gratuito -Oliveira Martins». A Voz, 20 de Out., 1953

«Sérgio plagiou ou não Oliveira Martins? Responde-se também por desfastio a algumas perguntas da oposição». A Voz, 21 de Out., 1953

«O Ministério do Interior responde”, a uma carta do sr. António Sérgio». A Voz, 27 de Out., 1953

\section{c2 ASSINADOS}

Almeida, António - «Lembrança de António Sérgio». Brotéria, n. ${ }^{\circ}$ 7, Julho, 1970. 93-95 pp.

Almeida, Ramos de - «Perfis indiscretos. António Sérgio». Jornal de Notícias, 13 de Jul., 1959

Antunes, Manuel — «António Sérgio (1883-1969)». Brotéria, Fev. 1969, 266-267 pp.

Azevedo, Adalberto - «António Sérgio duas palavras a um jovem a propósito de uma ideia do autor dos Ensaios», seguido de: «Homenagem» e «Recupere-se a casa onde viveu o grande ensaista». Diário Popular, Suplemento, 14 de Jan., 1982

Baptista, António Alçada - «Reflexões sobre a morte de António Sérgio». O Tempo e o Modo, n. ${ }^{\circ}$ 69-70, Março-Abril, 1969, 311-313 pp.

Baptista, Jacinto - «Um simples episódio cooperativista». Diário Popular, 8 de Jan., 1969

Baptista, Jacinto - «A propósito da reimpressão de António Sérgio, o idealismo crítico e a crise da ideologia burguesa de Vasco Magalhães-Vilhena». Diário Popular, 26 de Jun., 1975

Baptista, Jacinto - «Observações de António Sérgio sobre um projecto de estatutos da União Geral dos Combatentes da República». O Ponto, 22 de Julho, 1982. (C/ uma carta de Bernardino Machado a Luisa Sérgio)

Baptista, Jacinto - Artigo sobre António Sérgio. O Ponto, n. ${ }^{\circ}$ 59, 17 de Dez., 1982

Baptista, Jacinto - «Socialização s/ estatismo. A sociedade visionada por António Sérgio». Correio do Minho, 29 de Jan., 1983 (Inquérito publicado $\mathrm{s} /$ as perguntas no Diário da Noite, 6.5.1932, e publicado aqui completo)

Barreira, Cecília - «António Sérgio e a reforma pedagógica». Diário de Lisboa, 24 de Jan., 1981

Barreira, Cecília- «António Sérgio: um modo de efabular». Diário de Notícias, 21 de Dez., 1982

Barreira, Cecília - «Cronologia biográfica de António Sérgio». O Ponto, n. ${ }^{\circ} 59,17$ de Dez., 1982

Barreira, Cecília - «Uma entrevista de António Sérgio à Revista Portuguesa (28.7.927)». Diário de Lisboa, 6 de Jan., 1981

Barreto, Luis Filipe - «António Sérgio, a História e o conceito de Renascimento». História, revista mensal, Ag. 1981, 56-74 pp.

Barreto, Luis Filipe - «Em torno de Sérgio». Brotéria, n. ${ }^{\circ}$ 3, Mar., 1979, 261-270 pp.

Barreto, Luis Filipe - «Pensando Sérgio». Brotéria, n. ${ }^{\circ}$ 5-6, Maio-Jun., 1978, 562-566 pp. 
Barros, Henrique de - «Breve nota sobre o cooperativista Sérgio»; O Tempo e o Modo, n. ${ }^{\circ}$ 69-70, Mar.-Abr., 1969,. 319-321 pp.

Barros, Henrique de - «Mário de Azevedo Gomes mestre, companheiro, cidadão». Seara Nova, número especial do cinquentenário, 1971. (C/ interesse sergiano)

Barros, Henrique de - «Henrique de Barros evoca mensagem de António Sérgio». Jornal de Notícias, 28 de Jun., 1983

Barros, Henrique de - «Um balanço das comemorações». Diário de Notícias, (Suplemento especial), 3 de Set., 1983

Barros, Henrique de - «Sérgio e a era da Abundância». JL, Jornal de letras, artes e ideias, $n{ }^{\circ}$ 57, 4 de Abr., 1983

Beires, J. Sarmento - «António Sérgio: último encontro». Diário Popular, 2 de Abr., 1970

Boisvert, Prof. Georges - «Vitorino de Magalhães-Vilhena - António Sérgio o Idealismo Crítico e a Crise da Ideologia Burguesa, Seara Nova, 1965». Bulletin des Études Portugaises, Tomo 26, 1965, 253-256 pp.

(Referido em: «Uma crítica a Magalhães-Vilhena». Seara Nova, n. ${ }^{\circ} 1456$, Fev. 1967, 44 p.)

Branco, J. Freitas - «Homenagem a Sérgio? Filosofia em dinheiro graúdo» (depoimento). Diário de Lisboa, 7 de Mar., 1977

Brás, João - «Um grande português». Seara Nova, n. ${ }^{\circ} 323,3$ de Nov. 1932, 162 p., 173-174 pp.

A. C. «Homenagem a um contemporâneo do Futuro». República, 4 de Fev., 1969

Cabral, Manuel Villaverde - «Sérgio morto ou vivo». Expresso (Expresso Revista), 3 de Set., 1983

Caleiro, Maria da Conceição - «Sobre o sentido da História e do dever nacional em António Sérgio». Diário de Notícias, 8 de Set., 1983

Campos, Vieira de - «António Sérgio». Seara Nova, n. ${ }^{\circ} 90,3$ de Jun., 1926

Campos, Luis Vieira de «O burro de Buridan». Revista Portuguesa, n. 15, 23 de Jun., 1923, 3-8 p. (Sobre os Dispersos de Oliveira Martins organizados por A. S.)

Canana, Alfredo - «In Memoriam de António Sérgio». (C/ reprodução dos discursos proferidos no cemitério dos Prazeres quando da morte do escritor, do Prof. Dias Amado e dr. Fernando Mayer G arção). Diário de Lisboa, Suplemento, 29 de Jul., 1982

Caraça, Bento de Jesus - Correspondência trocada com a Vértice, a propósito da polémica c/ António Sérgio (5 cartas). Vértice, n. ${ }^{\circ}$ 394-95, Mar-.Abr., 1977

Caraça, Bento de Jesus - «Carta a António Sérgio-crítico». Vértice, n. 30-35, Maio de 1946, 126-140 pp. (Resposta ao artigo de A. S. «Réplica sem severidade a um severo Amigo» do n. ${ }^{\circ}$ 27-30 de Mar. 1946, da Vértice).

Caraça, Bento de Jesus - «Resposta a uma crítica». Vértice $\mathbf{n} .^{\circ} 22-26$, Fev. 1946, 35-44 pp. (Resposta ao artigo de A. S. do número anterior: "Nota a um passo de uma introdução a Berkeley»)

Cardia, Sottomayor - «Algumas palavras sobre António Sérgio». Idem, Jornal de alunos da Faculdade de Letras de Lisboa, 20 de Abr., 1964

Cardia, Sottomayor - «Notas à margem, António Sérgio em 1910». Espaço T Magazine, ${ }^{\circ}{ }^{\circ}$ 21, Lisboa, Mar., 1982

Cardia, Sottomayor - «O primeiro manifesto de Sérgio». Espaço T Magazine, n. ${ }^{\circ} 22$, Lisboa, Abr., 1982 
Cardia, Sottomayor- «Sérgio crítico de Sousa Martins». Espaço T Magazine, $n .^{\circ} 25$, Jul., 1982

Cardia, Sottomayor - "O jovem Sérgio e o cogito cartesiano». Espaço T Magazine, n. ${ }^{\circ}$ 27, Set., 1982

Cardia, Sottomayor - «O pensamento filosófico do jovem Sérgio». Lisboa, in: Revista Cultura-História e Filosofia, Vol. I, Instituto Nacional de Investigação Científica, 1982, 411-467 pp.

Carrilho, Manuel Maria - «Um criticismo fútil». Expresso, (Expresso Revista), 3 de Set., 1983

Carvalho, Montezuma de - «Ensaio todos os voos da mente não dogmática (Primeiro de Janeiro 4.7.962) e «Modelo de harmonia e concepção (Jornal do Comércio 7.9.963) República. 4 de Fev., 1969

Castro, Mário de - «Alegações finais do queixoso António Sérgio, no processo por abuso de liberdade de imprensa que moveu contra o jornal $A$ Voz». Seara Nova, n. $.^{\circ} 122,14$ de Junho. 1928, 23$-30 \mathrm{pp}$.

Catroga, Fernando - «Egídio Namorado um racionalista dialéctico» Prefácio a Ponto de Vista de Egídio Namorado. Coimbra, Textos Vértice, 2. ${ }^{\mathrm{a}}$ ed. $1977,5-39 \mathrm{pp}$. (C/ interesse para a análise do pensamento filosófico de $\mathrm{A}$. S.)

Cautela, Afonso - "António Sérgio: a vacina antitotalitária». Portugal Hoje, 28 de Jan., 1982

Chaves, Castelo Branco - «António Sérgio. Páginas de Recordações do seu tempo de Marinheiro (in Memoriam)». Anais do Club Militar Naval, Lisboa, n..$^{\circ} 1$ a 3, Jan.-Mar., 1969. (Publicado também em separata)

Chaves, Castelo Branco - «António Sérgio». Ensaio, jornal policopiado de estudantes. Director João de Freitas Branco, n. ${ }^{\circ}$, Abril de 1972

Chaves, Castelo Branco - «Notícia de um trabalho projectado sobre António Sérgio». Seara Nova, n. ${ }^{\circ} 1482$, Abril, 1969, 129-131 pp.

Chaves, Castelo Branco - «No quarto aniversário da morte de António Sérgio». República, 24 de Jan., 1973. (Artigo muito mutilado pela censura salazarista segundo informação dada pelo seu autor)

Chaves, Castelo Branco - «A primeira polémica de António Sérgio». A Capital, 9 de Abril, 1969

Chaves, Castelo Branco - «Análise rigorosa e solidez de pensamento». JL. Jornal de letras, artes e ideias, ${ }^{\circ}{ }^{\circ} 57,26$ de Abr., 1983

Chaves, Castelo Branco - «António Sérgio e a censura salazarista». O Jornal, 2 de Jan., 1983 (artigo publicado na República em Nov. de 1973, c/ as passagens eliminadas pela censura fascista e agora repostas e assinaladas)

Cidade, Hernani - «Ainda em torno da crise mental do séc. XVIII. Carta a António Sérgio». Seara Nova, n. ${ }^{\circ 220}, 18$ de Set., 1930, 51-53 pp.

Cidade, Hernani - «António Sérgio». O Primeiro de Janeiro, 12 de Mar., 1969

Correia, Natália - «Modernidade da doutrina social - mas rispidez filosófica...» $J L$, Jornal de letras, artes e ideias, $n .0^{\circ} 57,26$ de Abr., 1983

Cortesão, Jaime - «O Parasitismo e o anti-historismo». Carta a António Sérgio. A Vida Portuguesa, n. ${ }^{\circ} 18,2$ de Out., 1913, 153-159 pp.

Costa, Alberto - «Quel Héritage Renions-nous?». O Tempo e o Modo, n. ${ }^{\circ}$ 69-70, Mar.-Abr., 1969, 339 p. 
Costa, Alberto - «António Sérgio contra José Régio». Diário de Lisboa, 5 de Ag., 1965

Costa, Fernando Ferreira da - «Homenagem militante a António Sérgio». O Ponto, 7 de Jan., 1982

Costa, Fernando Ferreira da - «Dimensão Nacional de homenagem a António Sérgio e Memória Descritiva de Utilização da casa da Travessa do Moinho de Vento». O Ponto, 21 de Jan., 1982

Costa, Fernando Ferreira da - «Casa de António Sérgio (Memória descritiva de utilização)». Diário Popular, Suplemento, 28 de Jan., 1982

Costa, F. Ferreira da - «O cooperativismo como filosofia politica». Diário Popular, 24 de Jan., 1983

Costa, F. Ferreira da - «Para a História do Cooperativismo. Advertências de António Sérgio». Diário Popular, 8 de Out., 1982

Costa, Fernando Ferreira da - «Reformar a mentalidade portuguesa». Diário Popular, 26 de Mar., 1983

Costa, Fernando Ferreira da - «Do socialismo libertário à sociedade alternativa». $J L$, Jornal de letras, artes e ideias, $n .^{\circ} 57,26$ de Abr., 1983

Costa, Fernando Ferreira da - «O sector cooperativo em Sérgio e na Constituição». Diário Popular, 11 de Maio, 1983

Costa, Fernando Ferreira da - «Uma pedagogia prospectiva». Diário Popular, 22 de Maio, 1983

Costa, Fernando Ferreira da - «O socialismo cooperativista». Diário de Notícias, (suplemento especial), 3 de Set., 1983

Costa, João Benard da - «Dez anos depois». O Tempo e o Modo, n. ${ }^{\circ}$ 69-70, Mar.-Abr., 1969, 323-325 pp.

Costa, João Sá da - «Homenagem a Sérgio? Filosofia em dinheiro graúdo». (Depoimento). Diário de Lisboa, 7 de Mar., 1977

Costa, Ramos da - «O problema básico da Nacionalidade em António Sérgio", c/ carta inédita de A. S. sobre a teoria geral de Keynes. O Jornal, n. ${ }^{\circ}$ 199, 16 de Fev. 1979

Cunha, Norberto - «Conhecimento e História em António Sérgio». Gil Vicente, Revista de Cultura e actualidades, Jan.-Jun., 1983, 21 a 28 pp.

Dionísio, Sant’Anna - «Contestação das objecções de António Sérgio ao nosso modo de ver o pensamento de Leonardo Coimbra». O Diabo, n. ${ }^{\circ} 118,27$ de Set., 1936, 3, 5, 8 pp.

Dionísio, Sant'Anna - «O juízo crítico de António Sérgio sobre o valor da obra filosófica de Leonardo Coimbra». O Diabo, n. ${ }^{\circ} 127$, 29 de Nov., 1936, 4 p.

Dionísio, Sant'Anna - «Sobre a questão levantada por António Sérgio, ao valor de Leonardo Coimbra como pensador e a suposta consideração de Raul Proença por ele, nessa qualidade». O Diabo, n. ${ }^{\circ} 115,6$ de Set., 1936, 2-6 pp.

Dionísio, Sant'Anna - «Terceira tentativa de rectificação dos juízos imprudentes de António Sérgio sobre o valor de Leonardo Coimbra como pensador». O Diabo, n. ${ }^{\circ} 125,15$ de Nov., 1936, $2,6 \mathrm{pp}$.

Esteves, Jose - «Como António Sérgio ensinou um católico a 1er os Evangelhos». Diário de Lisboa, 6 de Fev., 1969

Fernandes, Barahona - «António Sérgio um Homem Completo». A Capital, Suplemento de Literatura e Arte, 5 de Mar., 1969

Fernandes, Barahona - «Das Cartas de Problemática de António Sérgio». (1) A Capital, 9 de Abr., 1969

(2) Idem, 16 de Abr., 1969

(3) Idem, 30 de Abr., 1969 
Fernandes, Barahona-«A Psicologia na obra de António Sérgio», in: Revista Portuguesa de Psicologia, n. ${ }^{\circ}$ 12-13, 1975-1976, 129-139 pp.

Fernandes, Barahona - «Uma linha de cultura pós-sergiana». O Jornal, 9 de Jun., 1983

Fernandes, Rogério- «Para a revalorização crítica da cultura nacional». Seara Nova, n. ${ }^{\circ}$ 1435, Maio de 1965, 139-141 e 158 pp. (Sobre a obra de Magalhães Vilhena, António Sérgio, o Idealismo Crítico e a Crise da Ideologia Burguesal)

Fernandes, Rogério - «Comentário a um comentário» (sobre a crítica de José Régio ao livro de Magalhães Vilhena, António Sérgio, o Idealismo Crítico e a Crise da Ideologia Burguesa) Diário de Lisboa, Suplemento, 12 de Ag., 1965

Fernandes, Vasco da Gama - «Os últimos Ensaios de António Sérgio». Seara Nova, n. ${ }^{\circ} 313,25$ de Ag., 1932, 13-14 pp. (Sobre o tomo III dos Ensaios. Transcrito da Liberdade de 24.7.1932)

Fernandes, Vasco da Gama —Os cem anos de António Sérgio». Diário de Notícias, 29 de Maio, 1983

Ferreira, David - «O grupo da biblioteca rectificações e esclarecimentos para a história de um grupo que teve intervenção decisiva na vida e na cultura portuguesa das primeiras décadas deste século». Diário de Notícias, 25 de Jul., 1980

Ferreira, David Mourão - «António Sérgio crítico literário». Jornal de Letras e Artes, 14 de Fev, 1962 e 21 de Fev., 1962

Ferreira, David Mourão - «Em lembrança e louvor de António Sérgio». Diário de Notícias, 4 de Fev., 1980

Ferreira, José Gomes - «Nota pessoal sobre António Sérgio extraída de um diário íntimo». O Tempo e o Modo, n. ${ }^{\circ}$ 69-70, Mar.-Abr, 1969, 330-331 pp.

Ferreira, José Gomes - «Homenagem a Sérgio? Filosofia em dinheiro graúdo». (Depoimento). Diário de Lisboa, 7 de Mar., 1977

Ferreira, José Gomes - «Homenagem a Sérgio? Filosofia em dinheiro graúdo» (depoimento). Diário de Lisboa, 7 de Mar., 1977

Ferreira, José Medeiros - «António Sérgio e nós». O Tempo e o Modo, n. ${ }^{\circ}$ 69-70, Mar.-Abr, 1969, 331-333 pp.

Ferreira, Vergilio - «Questões prévias de um ignorante a um comentador de Sérgio». Critério, Revista mensal de cultura, n. ${ }^{\circ}$, Dez, 1975. (Texto de crítica ao ensaio de V. Magalhães Vilhena: António Sérgio o idealismo crítico e a crise da ideologia burguesa), 18-26 pp.

Fonseca, Tomaz da - «Do calcanhar do mundo» (o problema agrário, salientando os aspectos sociais na óptica de A. S.). República, 17 de Ag, 1954

França, José Augusto - «Homenagem a Sérgio». (Sobre o livro de homenagem a A. S. publicado pela Academia das Ciências em 1976). Diário Popular, 3 de Mar, 1977

Franco, A. L. Sousa - «Sérgio e a economia». JL, Jornal de letras, artes e ideias, $n .^{\circ} 57,26$ de $\mathrm{Abr}, 1983$

Gama, Jaime - «António Sérgio e nós». O Tempo e o Modo, n. ${ }^{\circ} 69-$ -70 , Mar.-Abr, 1969, 322-323 pp.

Gama, José- «A polémica saudosista: Teixeira de Pascoais e António Sérgio». Brotéria, n. ${ }^{\circ}$, Fev, 1982, 185-193 pp.

Garcia, Mário - «A campanha saudosista de Teixeira de Pascoais e a sua polémica com António Sérgio». Revista Portuguesa de Filosofia, Braga, Jan.-Mar, 1976, 1-32 pp. 
Godinho, Vitorino Magahães - «António Sérgio: Presença do Passado - Presença do Futuro». Seara Nova, n.? 1507, Maio, 1971, 36-38 pp.

Godinho, Vitorino Magalhães - «O Portugal que somos e o Portugal que queremos ser» seguido de «Excerptos de António Sérgio». Tempo Livre, ano I, n. 3 , Out., 1977 (ed. da F.A.O.J.) 33 a 36 pp.

Gomes, Fernando Costa - «Apontamentos para o estudo da pedagogia em António Sérgio». Diário de Lisboa, 16 de Fev., 1965

Gomes, Manuel Teixeira - «Uma carta de Teixeira Gomes». Seara Nova, n. ${ }^{\circ}$ 96, 16 de Jan., 1930. (Sobre a tradução inglesa da História de Portugal de A. S.)

Gomes, Teixeira - «Carta a António Sérgio sobre o segundo volume dos seus Ensaios». Seara Nova, n. ${ }^{\circ} 220,18$ de Set., 1930, 55-56 pp.

Guisado, Alfredo - «Sobre o conceito de Civilização Cristã» (ref. à ed. da Biblioteca dos Fenianos, Porto, da conf. a que ${ }^{\wedge}$ A. S. aí proferiu a 5.2. c/ transcr. de algumas passagens). Republic a, 26 de Maio, 1948

Graça, Fernando Lopes - «Testemunho». O Tempo e o Modo, n. ${ }^{\circ}$ 69-70, Mar.-Abr., 1969, 316-317 pp.

Grácio, Rui - «Pedagogia de Aeção Social e Racional de António Sérgio». Seara Nova, n. ${ }^{\circ}$ 1370, Dez., 1959, 389-398-399 pp.

Lapa, Rodrigues - «António Sérgio e o galego». Diário de Notícias, 12 de Jun., 1979. (Publ. em: Estudos Galego-Portugueses, Lisboa, Livr. Sá da Costa, 1979, 117-129 pp.)

Lobo, Manuel de Sousa - «Adeus de gratidão». Diário Popular, 30 de Jan., 1969

Lopes, Fernando Farelo - «A rendição da cultura liberal». Análise Social, n. $^{\circ} 64,1980$

Lopes, Fernando Farelo - «Bernardino Machado e a União Cívica». António Sérgio em resposta a Bernardino Machado e por causa da União Cívica: o que era preciso era uma «ditadura de honradez» com «homens de boa vontade»e independentemente da sua cor política. Diário de Notícias, 20 de Abr., 1982

Lopes, Fernando Farelo - «O socialismo sergiano: o Estado e a política». Expresso (Expresso revista), 3 de Set., 1983

Lopes, Óscar - "A crítica do livro. António Sérgio. Ensaios tomo VII», Lisboa, 1954. O Comércio do Porto, 11 de Jan., 1955

Lopes, Óscar - «A critica literária nos Ensaios de António Sérgio». Seara Nova, n. ${ }^{\circ} 1369$, Nov., 1959, 341-42 pp.

Lourenço, Eduardo - «Sérgio como mito cultural»». O Tempo e o Modo, n. ${ }^{\circ}$ 69-70, Mar. de 1969, 250-260 pp. (Reproduzido em: O Labirinto da Saudade, Lisboa, Publ. D. Quixote, 1978)

Lourenço, Eduardo - «António Sérgio e o estatuto da Razão». Expresso (Expresso Revista), 10 de Set., 1983

Marinho, José - «Anotações a uma nota». Seara Nova, n. ${ }^{\circ} 431,21$ de Mar., 1935, 355-361 pp. (Sobre uma «nota» que A. S. apôs ao texto de José Marinho publicado no n. ${ }^{\circ} 423$ da Seara Nova)

Marinho, José - «Resposta a um idealista de um amigo de pensar inclassifiçado». Seara Nova, n. ${ }^{\circ}$ 423, 10 de Jan., 1934, 227-229 pp. (Resposta aos artigos de A. S. dos n. ${ }^{\circ} \mathbf{s} 410$ e 411 da Seara Nova. «Esclarecimentos e interrogações de um idealista»)

Marnoto, Isabel - "António Sérgio e os frasquinhos de sabença». $O$ Ponto, 12 de Nov., 1981

Marnoto, Isabel - «Viver à custa da obra dos outros - um pecado que Vergilio Ferreira não perdoa a António Sérgio...». Diário Popular, Suplemento de Letras e Artes, 6 de Maio, 1982 
Marnoto, Isabel - «Retrato a preto e branco». $J L$, Jornal de letras, artes e ideias, $n .^{\circ}$ 57, 26 de Abr., 1983

Marques, A. H. de Oliveira- «António Sérgio Historiador». O Tempo e o Modo, n. ${ }^{\circ}$ 69-70, Mar., 1969, 303-310 pp.

Martins, Guilherme d'Oliveira- "António Sérgio hoje». Diário de Notícias, 20 de Maio, 1983

Martins, Guilherme d'Oliveira - «Uma atitude plenamente actual». Diário de Notícias, (suplemento especial), 3 de Set., 1983

Matos, A. Campos - «Diálogo com António Sérgio». (Entrevista elaborada c/ textos sergianos, de um livro com o mesmo título no prelo). $J L$, Jornal de letras, artes e ideias, $n .^{\circ} 57,26$ de Abr., 1983

Medina, João - «António Sérgio afinador de pianos». O Ponto, 13 de Nov., 1980

Medina, João - «O ideário da Liga de Acção Nacional expresso na revista Pela Grei». Diário Popular, 28 de Dez., 1978

Medina, João - «A Liga de Acção Social e o Sidonismo». Diário Popular, 21 de Dez., 1978

Medina, João - «Sérgio Sidonista». Diário Popular, 14 de Dez., 1978

Mendes, João - «Vida Literária». (Crítica ao $70^{\circ}$ vol. dos Ensaios). Brotéria, Dez., 1954, 573-577 pp.

Mendes, João - «Vida Literária» Ensaios (crítica à 2. a ed. do $2 .^{\circ}$ vol.). Brotéria, Abr., 1958, 459-462 pp.

Mendes, Manuel - «Os Ensaios de António Sérgio». República, 19 de Nov., 1949

Mendes, Manuel- «A propósito da morte de António Sérgio». O Primeiro de Janeiro, 12 de Mar., 1969

Mendes, Manuel — «António Sérgio — a Pertinácia da Razão». Seara Nova,.$^{\circ} 1483$, Maio, 1969, 169-170 pp.

Mendes, Manuel - «O compromisso e o drama da Inteligência». O Tempo e o Modo, n. ${ }^{\circ}$ 69-70, Mar.-Abr., 1969, 333-335 pp.

Mendes, Manuel - «Como Proença saudou o aparecimento de um grande livro». Seara Nova, n. ${ }^{\circ}$ 1433, Mar., 1965, 67, 68 e 95 pp. (Sobre o Tomo I dos Ensaios de A. S.)

Mendes, Manuel — «Velhas leituras». A Capital, 29 de Jan., 1969

Miguéis, José Rodrigues - «Os acordes dissonantes». Seara Nova, n. ${ }^{\circ}$ 1440, Out., 1965, 309-311 pp. (Sobre uma reprimenda que o autor recebeu de A.S. a proposito do parágrafo final do Bosquejo da História de Portugal)

Miguéis, José Rodrigues - «Uma flor na campa de Raul Proença, A crise mental». Diário Popular, 19 de Abr., 1979. (C/ uma ref. de interesse sobre tentativas de suicídio do autor dos Ensaios)

Miguéis, José Rodrigues - «Uma flor na campa de Raul Proença. O Cacete Florido e a obra de criação pessoal». Diário Popular, 26 de Abr., 1979. (C/ ref.as de interesse a A. S. polemista)

Moncada, Prof. Cabral de - «Idealismo e Realismo. Fim de uma polémica inútil». Nação Portuguesa, Lisboa, Fase. 6, Tomo I, 1929, $57-78$ pp.

Morgado, Guilherme - «O programa cooperativo por Carlos Gide», trad, de um grupo de seareiros - pref. de A. S., ed. Seara Nova, Lisboa, 1939. O Diabo, n. ${ }^{\circ} 229,11$ de Fev., 1939

Múrias, Manuel - «Resposta à letra... António Sardinha e o sr. António Sérgio». Nação Portuguesa, n. ${ }^{\circ}$ 7-8, 1925, 139-145 pp. Idem, n. ${ }^{\circ}$ 9-10, 1926, 184-197 pp.

Namorado, Egídio - «Uma carta a Joel Serrão». Vértice, n. ${ }^{\circ}$ 394-95, Mar.-Abr., 1977, 193-206 pp. 
(Trata-se de duas cartas do autor a Joel Serrão sobre o ensaio daquele denominado: "Montagem de textos para uma interpretacão do pensamento filosófico de António Sérgio)

Namorado, Egídio - «Em torno da obra e personalidade de António Sérgio: montagem de textos para uma interpretação do pensamento filosófico de António Sérgio». Vértice, n. ${ }^{\circ}$ 394-95, Mar.-Abr., 1977, 171-188 pp. (Publicado pela l. ${ }^{\text {a }}$ vez em Vértice, n. ${ }^{\circ}$ 319-20, Ag.-Set., 1970. Contém: «Uma carta de Joel Serrão»; "Carta a Joel Serrão» de Egídio Namorado e «Alguns documentos sobre a polémica António Sérgio - Bento de Jesus Caraça»)

Nogueira, A. Costa- «Dois historiadores e um crítico. Carta aberta ao sr. António Sérgio». Acção, 21 de Jun., 1945

Nogueira, Jofre Amaral - "Carta ao sr. António Sérgio». Sol Nascente, 15 de Nov., 1937, 7 p.

Nogueira, Jofre Amaral - "Comentário para compreender». Sol Nascente, 15 de Dez., 1937, 6-7 pp.

Nogueira, Jofre Amaral - "Méritos e limitações de um apostolado». Vértice, n. ${ }^{\circ}$ 314, Mar., 1970, 177-190 pp.

Oliveira, Barradas de - «António Sérgio e o Fascismo». Gil Vicente - Revista de Cultura e Actualidade, Guimarães, vol. I, n. ${ }^{\circ}$ 3, Ag.-Set., 1980, 233-236 pp. (Reproduzido também em A Rua de 20 de Mar., 1981)

Oliveira, Prof. J. Tiago de - «António Sérgio. Um exercício de racionalismo». Seara Nova, n. ${ }^{\circ}$ 1484, Jun., 1969, 201-202 pp.

Pacheco, J. Preto - «Ponto nos ii». Seara Nova, n. ${ }^{\circ} 168,4$ de Jul., 1929, 377-379 pp. (Continuação da resposta do autor à crítica de A. S. ao seu D. Sebastiäo)

Pacheco, J. Preto - «Resposta Sincera». Seara Nova, n. ${ }^{\circ} 152,14$ de Mar., 1929, 122-124 pp. (Sobre a crítica de A. S. ao livro D. Sebastião do autor)

Pacheco, Luis - «O problema dos dispersos». Diário Popular, 17 de Ag., 1983

Pedroso, Alberto - «Uma intervenção ignorada de António Sérgio». Seara Nova, n. ${ }^{\circ} 1596 / 97$, Out.-Nov., 1978, 27-29 pp.

Pedroso, Alberto - «Uma carta inédita de António Sérgio. Em torno das suas objecções quanto aos fins da Universidade Popular». $A$ Cidade, revista cultural de Portalegre,.$^{\circ} 3$, Fev., 1982

Pereira, Alice Vassalo — «António Sérgio crítico literário». Diário de Lisboa, 16 de Fev., 1965

Pereira, Arnaldo A «A contribuição de António Sérgio na nossa historiografia». Diário de Lisboa, 16 de Fev., 1965

Pereira, Vitorino - «A nossa estante. Democracia de António Sérgio». O Trabalho, Semanário Republicano. Viseu, n. ${ }^{\circ} 251,28$ de Jul., 1938

Pimentel, Sarmento - «António Sérgio secretário e intérprete de um grande e famoso industrial português no Brasil». O Ponto, n. ${ }^{\circ}$ 59, 17 de Dez., 1982

Pinto, Álvaro - «A influência da Águia no movimento literário português. Álvaro Pinto responde a António Sérgio». Diário de Lisboa, 29 de Jun., 1935

Pinto, Álvaro - «Uma carta sobre a questão do saudosismo». O Diabo, n. ${ }^{\circ} 133,10$ de Jan., 1937, 8 p.

Pires, José Cardoso - «Repensar Portugal», O Tempo e o Modo, n. ${ }^{\circ}$ 69-70, Mar.-Abr., 1969, 327-330 pp.

Ponte, Bruno da - «António Sérgio, o Idealismo Crítico e a Crise da Ideologia Burguesa - de V. Magalhães Godinho O» Jornal de 
Letras e Artes, 9 de Jun., 1965. O Por lapso. Trata-se de V. Magalhães Vilhena

Portela, Artur História Trágico Marítima, Artur Portela comenta e critica a obra anotada e prefaciada por António Sérgio. Diário de Lisboa, 25 de Jan., 1956

Portela, Artur Naufrágios e combates no mar, Textos seleccionados e comentados por António Sérgio. Diário de Lisboa, Suplemento, 16 de Maio, 1958

Proença, Raul - «Um livro de claridades e de sombras». Seara Nova, n. ${ }^{\circ}$ 3, 20 de Nov., 1921, 77-81 pp. (e/ um retrato de A. S.)

Proença, Raul - «António Sérgio e o seu monarquismo ante o olhar purissimo de certas vestais republicanas». Seara Nova,.$^{\circ} 29$, 20 de Jan., 1924, 100-101 pp.

Queiroz, Alberto Gimenez - «Algumas considerações». Diário de Lisboa, 16 de Fev., 1965

R. p_ "Antero de Quental e António Vieira perante a civilização cristã dos seus próprios tempos, por António Sérgio. Vértice, n. ${ }^{\circ} 59$, Jul., 1948, 31-32 pp. (Na secção de «Critica»)

Ramos, Mário - «Para a crítica do crítico sr. António Sérgio». O Diabo, n. ${ }^{\circ}$ 164, 14 de Nov., 1937, 7 p. (Sobre o materialismo sergiano a propósito da Tese e antítese nos sonetos de Antero)

Ramos, Mário - «Para a crítica do crítico sr. António Sérgio: segunda contribuição». O Diabo, n. ${ }^{\circ}$ 168, 12 de Dez., 1937, 2 p.

Rau, Virgínia- «A exploração e o comércio do sal de Setúbal». Estudo de História Económica -1, Lisboa, 1951, obra resumida e ampliada em: «Rumos e vicissitudes do comércio do sal português nos sécs. XIV a XVIII, in Revista da Faculdade de Letras, Universidade de Lisboa, Ills. n. ${ }^{\circ}$ 7, 1963. (Trabalhos relacionados com a hipótese proposta por A. S. no Bosquejo da História de Portugal, sobre ser o sal o principal produto da nossa exportaç̃o marítima)

Rebelo, Pequito - «Regionalismo Realista» (sobre as noções de raça e descentralização). A Monarquia - Diário integralista da tarde, 7 de Jul., 1917

Rebelo, Pequito - «A Suissa» (ref. ${ }^{a}$ ao regionalismo e descentraliza(̧ão) ${ }^{\wedge}$ Monarquia - Diário integralista da tarde, 18 de Jul., 1917

Rebelo, Pequito - «Polémica terminada» (ref. resposta de A. S. no diário de $A$ Manhã cujo director é Álvaro Pinto). A Monarquia-Diário integralista da tarde, 17 de Set., 1917

Rebelo, Pequito - «O caso da Suissa». $A$ Monarquia - Diário integralista da tarde, 30 de Jul., 1917

Régio, José — «António Sérgio e o Sol Nascente». Presença, n. ${ }^{\circ}$ 51, Mar. de 1938, 14-15 pp.

Régio, José - «Um livro a propósito de António Sérgio». (Trata-se do livro de Magalhães Vilhena: António Sérgio, o Idealismo Crítico e a Crise da ideologia burguesa). Diário de Lisboa, Suplemento, 22 de Jul., 1965

Régio, José - "Comentário a um comentário» (conclusão). Diário de Lisboa, 23 de Set., 1965

Rego, Raul - "António Sérgio o intelectual e o cidadão indomável». Diário de Lisboa, 25 de Jan., 1969

Rego, Raul- «Centenário a não esquecer». Correio do Minho, 15 de Jan., 1983

Rego, Raul - «O jovem Sérgio». Diário Popular, 22 de Mar., 1983 (sobre o estudo de Sottomayor Cardia da revista Cultura)

Rego, Raul - «Livros raros. Rimas de António Sérgio». Diário de Notícias, 17 de Abr., 1983 
Rego, Raul-«Livros raros. Antigona de António Sérgio». Diário de Notícias, 24 de Abr., 1983

Rego, Raul - «Livros raros. O Navio de Brinquedos». Diário de Notícias, 1 de Maio, 1983

Rego, Raul - «Livros raros. A História de Portugal da Labor». Diário de Notícias, 8 de Maio, 1983

Rego, Raul «Livros raros. Educação Cívica». Diário de Notícias, 12 de Jun., 1983

Rego, Raul - «A questão do regime para António Sérgio». Diário Popular, 6 de Set., 1983

Reis, Câmara - «Lealdade e boa educação». (Carta de Câmara Reis a João Gaspar Simões sobre a polémica deste autor com António Sérgio). Seara Nova, n. ${ }^{\circ} 306,7$ de Jul., 1932

Reis, Jaime Batalha - «Depoimentos». Seara Nova, n. ${ }^{\circ}$ 98, Abr., 1927. (De Gago Coutinho e Jaime Batalha Reis sobre A. S.)

Ribeiro, Afonso - «Resposta a um comentário». Sol Nascente, 15 de Maio, 1938, 9 p. (Resposta a José Régio sobre a polémica Abel Salazar - António Sérgio)

Ruas, Henrique Barrilaro - "O exercício exemplar de análise critica». Diário de Notícias (suplemento cultural), 3 de Set., 1983

Sá, Victor de - «Homenagem a Sérgio». Seara Nova, n. ${ }^{\circ} 1441$, Nov., 1965, 329-330 pp. (Transcrição do artigo do autor, do suplemento cultural de O Comércio do Porto, de 10 de Ag., 1963 sobre o livro de Magalhães Vilhena: António Sérgio, o Idealismo Crítico e a Crise da Ideologia Burguesa)

Sá, Victor de - «António Sérgio». O Jornal, 29 de Dez., 1978

Sá, Victor de - «O problema básico da nacionalidade em António Sérgio». Historia, Publicação mensal, n. ${ }^{\circ}$, Fev., 1979, 34 a 41 pp.

Sá, Victor de - «Sérgio: Que nação somos, que poderemos ser?». Vértice, $n .^{\circ}$ 417-418, Mar.-Abr., 1979, 153-159 pp.

Sacramento, Mário - "António Sérgio - o ensaísta e o doutrinário». Vértice, n. ${ }^{\circ} 313$, Fev., 1970, 89-100 pp.

Sacramento, Mário - «Eis a crítica querido mestre e Amigo». Diário de Lisboa, Suplemento literário, 30 de Jan., 1969

Salema, Álvaro - «Uma interrogação sergiana». República, 16 de Jan., 1959

Salema, Alvaro - «António Sérgio e o espírito seareiro». Seara Nova, n. ${ }^{\circ}$ 1391-92, Set.-Out., 1961, 205-210 pp.

Santos, Fernando Piteira - «Uma antologia viva dos problemas nacionais escreve Fernando Piteira Santos a propósito das antologias de Sérgio». República, 17 de Set., 1956

Santos, Fernando Piteira — «Um prefácio sombrio e um livro luminoso». (Sobre a 2.a ed. dos Ensaios I). República, 19 de Maio, 1957

Santos, Fernando Piteira — «António Sérgio e Fernando Pessoa, Uma carta inédita escrita do exílio e um inquérito literário no exílio imaginado». República, Suplemento, 18 de Abr., 1974

Santos, Fernando Piteira - «Acerca dos Ensaios de António Sérgio e da sua atitude ensaística». Diário Popular, 6 de Fev., 1975

Santos, Fernando Piteira - «Notas de Introdução a uma leitura de Sérgio». Clio, Revista do Centro de História da Univ. de Lisboa, 1979, 155-160 pp.

Santos, Fernando Piteira - «António Sérgio: o Escritor e o Discurso Ensaístico». Vértice, n. ${ }^{\circ} 446$, Jan.-Fev., 1982, 7-15 pp.

Santos, Fernando Piteira - «Breve depoimento sobre António Sérgio». O Tempo e o Modo, ${ }^{\circ}{ }^{\circ}$ 69-70, Mar.-Abr., 1969, 317-319 pp. 
Santos, Fernando Piteira - «Proença e Cortesão leitores de António Sérgio». República, 16 de Mar., 1974

Santos, Fernando Piteira - «Uma personalidade ímpar». JL Jornal de letras, artes e ideias, $n .^{\circ}$ 57, 26 de Abr., 1983

Santos, Fernando Piteira - "Marx, Sérgio e o que adiante se lerá» (coluna política de A a Z). Diário de Lisboa, 30 de Set., 1983

Santos, Nuno Carvalho dos - «António Sérgio: centenário do racionalismo». A Tarde, 11 de Out., 1983

Salazar, Abel «O bluff António Sérgio». Sol Nascente, n. ${ }^{\circ} 22,1$ de Jan., 1938, 4, 5 e 13 pp.

Salazar, Abel - «Carta a António Sérgio». O Diabo, n. ${ }^{\circ}$ 155, 13 de Jun., 1937, 8 p.

Salazar, Äbel- «Uma carta do dr. Abel Salazar ao director do Sol Nascente». Sol Nascente, n. ${ }^{\circ} 24$ de Fev., 1938, 14 p. (para «suspender os 10 artigos em que definia o triste personagem que é o sr. António Sérgio»)

Salazar, Abel - «As críticas de António Sérgio e a necessidade de actualização do pensamento português». O Diabo, n. ${ }^{\circ} 156,20$ de Jun., 1937, 8 p.

Salazar, Abel - «Pela segunda vez ao sr. António Sérgio». Sol Nascente, $\mathrm{n} .^{\circ} 23,15$ de Jan., 1938, 4, 5 e 13 pp.

Salazar, Abel - «A propósito da vulgarização do Círculo de Viena (resposta a António Sérgio)». Sol Nascente, n. ${ }^{\circ}$ 10, 15 de Jun., 1937, 8-9 pp.

Saraiva, António José - «Sobre a 2.a edição dos Ensaios de António Sérgio». Vértice, n. ${ }^{\circ}$ 81, Maio, 1950, 279-292 pp. (Trata-se do tomo I)

Saraiva, António - «António José Saraiva continua o artigo de Sérgio de 21 de Junho Ainda a propósito do Cooperativismo». República, 24 de Jun., 1955

Saraiva, António José - "Sobre as polémicas na cultura portuguesa» (c/ ref.as a A. S.). Vida Mundial, n. ${ }^{\circ}$ 1673, 2 de Jul., 1971, 17-18 pp.

Sena, Jorge de - «Depoimento sobre António Sérgio». O Tempo $e$ o Modo, n. ${ }^{\circ}$ 69-70, Mar.-Abr., 1969, 326-327 pp.

Serrão, Joel - «Para uma interpretação do ensaio histórico-pedagógico de António Sérgio». Seara Nova, n. ${ }^{\circ}$ 1365, Jul., 1959, 207, 214-216, 227 pp.

Serrão, Joel- «Breve nota sobre sergianismo ideal». Diário de Lisboa, 16 de Fev., 1965

Serrão, Joel - «Para uma caracterização do ensaísmo de António Sérgio». O Tempo $e$ o Modo, n. ${ }^{\circ}$ 47-48, Lisboa, Mar.-Abr., 1967, 331-340 pp.

Serrão, Joel — «Nota sobre a importância do método no ensaísmo de António Sérgio». Seara Nova, n. ${ }^{\circ} 1461$, Jul., 1967, 205-206 pp.

Serrão, Joel - «António Sérgio, o Educador». O Tempo e o Modo, n. ${ }^{\circ}$ 69-70, Mar., 1969, 242-249 pp.

Serrão, Joel - «Homenagem a Sérgio? Filosofia em dinheiro graúdo». (Depoimento). Diário de Lisboa, 7 de Mar., 1977

Serrão, Joel - «Uma carta de Joel Serrão». Vértice, n. ${ }^{\circ}$ 394-95, Mar.-Abr., 1977, 189-192 pp. (Esta carta diz respeito ao ensaio de Egídio Namorado publicado neste $n .^{\circ}$ da Vértice c/ o título: «Montagem de textos para uma interpretação do pensamento filosófico de António Sérgio)

Serrão, Joel - «Sérgio, historiador e pedagogo». Diário de Notícias, Caderno de História, 12 de Jun., 1979 
Sertório, Manuel - «Da cabeça para os pés». O Tempo e o Modo, n. ${ }^{\circ}$ 69-70, Mar.-Abr., 1969, 336-338 pp.

Sertório, Manuel - «O Directorio Democrata-Social e a candidatura de Delgado» (c/ ref. as de interesse sobre a actividade politica de A. S.). O Jornal, 1 de Jul., 1983

Soares, João Pedro - «Reflectir António Sérgio ou o interesse dos consumidores». O Comércio do Porto, 9 de Set., 1983

Soares, Luisa Ducla - «António Sérgio e a literatura infantil». Diário de Notícias, 16 de Dez., 1980

Silva, Agostinho da - «Ombrear com Herculano». $J L$ Jornal de letras, artes e ideias, $n .^{\circ}$ 57, 26 de Abr., 1983

Silva, Carlos da - «António Sérgio e nós». O Tempo e o Modo, n. ${ }^{\circ}$ 69-70, Mar.-Abr., 1969, 313-316 pp.

Simões, João Gaspar - «A propósito de uma nota sobre poesia, do sr. António Sérgio». Seara Nova, ${ }^{\circ}{ }^{\circ} 290,17$ de Maio, 1932

Simões, João Gaspar - «Última contribuição para desfazer um equívoco do sr. António Sérgio». Presença, n. ${ }^{\circ}$ 35, Mar.-Maio, 1932, 13,17 e 20 pp.

Sousa, Pedro de - «As Obras Completas de António Sérgio». Brotéria, n. ${ }^{\circ}$ 8-9, Ag.-Set., 1971, 209-210 pp.

Taipa, Orlando - «José Régio e Antonio Sérgio». Vida Mundial, 25 de Set., 1970

Teixeira, António Braz - «Um filósofo mais conhecido pelos aspectos menores da sua obra». $J L$, Jornal de letras, artes e ideias, $n .^{\circ} 57$, 26 de Abr., 1983

Valdemar, António - «A questão sebástica nas polémicas de Sérgio». Diário de Notícias, 3 de Set., 1983

Valente, Júlio - «António Sérgio e a auto-educação». A Luta, 6 de Set, 1976

Valente, Vasco Pulido - «António Sérgio de Sousa: uma revolução interior». O Tempo e o Modo, n. ${ }^{\circ}$ 69-70, Mar, 1969, 261-302 pp.

Vilhena, V. Magalhães - "António Sérgio e a filosofia». Seara Nova, n. 1368, Out, 1959, 305-308 pp. (Ensaio publicado em 1960 nas ed. Cosmos e desenvolvido em António Sérgio, o Idealismo Crítico e a Crise da Ideologia Burguesa, Seara Nova, 1964. (Esta última obra foi reimprensa pelas ed. Cosmos em 1975)

\section{Ild PUBLICAÇÕES ESPECIAIS DE HOMENAGEM OU COMEMÓRAÇÃO}

Diário de Lisboa. Juvenil. Número dedicado a António Sérgio n. ${ }^{\circ}$ 404, 16 de Fev, 1965. (Contém: «A. S. Crítico literário» de Alice Vassalo Pereira; «Breve nota sobre sergianismo ideal de Joel Serrão; "Apontamentos para o estudo da pedagogia em A. S.» de Fernando Costa Gomes; «Algumas considerações» de Alberto Gimenez Queiroz; "A contribuição de A. S. na nossa historiografia» de Arnaldo A. Pereira e «O pensamento de A. S.» trechos recolhidos por Alberto G. Queiroz

Diário de Notícias. Caderno História. 12 de Jun, 1979. (Contém: «Sérgio, historiador e pedagogo» de Joel Serrão; «António Sér- 
gio e o galego» de Rodrigues Lapa e «Carta aberta a um conservador lusitano» de A. S.)

Diário de Notícias. Suplemento especial dedicado a António Sérgio, 3 de Set., 1983. (Contém: Sete cartas inéditas a Carlos Malheiro Dias e uma resposta de Malheiro Dias; António Valdemar - «A questão sebástica nas polémicas de Sérgio»; Henrique de Barros - «Um balanço das comemorações»; Henrique Barrilaro Ruas «O exercício exemplar da análise crítica»; Fernando Ferreira da Costa - «O socialismo cooperativista»; Guilherme de Oliveira Martins - «Uma atitude plenamente actual»)

Homenagem a António Sérgio. Lisboa, Academia das Ciências de Lisboa, 1976, 151 p. (C/ colaboração de Manuel de Almeida Lima, António da Silveira, Joel Serrão, David Mourão Ferreira, Henrique J. de Barahona Fernandes e Vasco Magalhães Vilhena)

O Tempo e o Modo, n..$^{\circ}$ 60-70, Março-Abril, 1969. (C/ colaboração de: Joel Serrão, Eduardo Lourenço, Vasco Pulido Valente, A. H. de Oliveira Marques, António Alçada Baptista, Carlos da Silva, Fernando Lopes Graça, Fernando Piteira Santos, Henrique de Barros, Jaime Gama, João Benard da Costa, Jorge de Sena, José Cardoso Pires, José Gomes Ferreira, José Medeiros Ferreira, Manuel Mendes, Manuel Sertório e Alberto Costa)

Vida Mundial, n. ${ }^{\circ}$ 1548, 7 de Fev., 1969. (C/ notas sobre o homem e a obra em «Um perfil e uma Obra»; documentação fotográfica; breve antologia e bibliografia, 34-45 pp.)

Revista da Associação dos Antigos Alunos do Colégio Militar, Lisboa, n. ${ }^{\circ 5}$, Nov.-Dez., 1976, 66 p. (Contém: «António Sérgio e os porquês de um número especial»; "António Sérgio o Colégio e a Âssociação» c/ um texto de A. S.; "Traços biográficos de Ântónio Sérgio»; "António Sérgio de Sousa, algumas datas»; "Caracterização de António Sérgio», c/ excertos dos Ensaios, Grande Enciclopédia Portuguesa e Brasileira, contra-capa das ed. Sá da Costa, Enciclopédia Focus, artigo do Diário Popular de António de Sequeira Zilhão de 13.2.1969 — «Exemplo de estoicismo», «o pensamento ao serviço da realidade» de Neves Águas da Vida Mundial de 7.2.1969 e "Idealismo crítico» de Vasco Magalhães Vilhena; «Carta de António de Sousa a seu filho António» de 26.5.1896»; «Da psicologia para a Epistemologia - o humanismo criativo de António Sérgio» de H. Barahona Fernandes; "António Sérgio e a auto-educação» de Júlio Valente; «Os contos infantis de António Sérgio em cinema» de Eduardo Sergio; "Uma carta e duas respostas» - respostas de: Bispo do Porto e de C. F. Torre de Assunção; «Retalho antológico»: «Ao jovem leitor» (pref. dos Ensaios II), «Diante de um presépio» (Ensaios VI, «O jogral de Deus» (Ensaios VI), «Essa sim que é cristã!» (Perante a inexistência de uma civilização cristã), «O primado da cultura» (Ensaios II), «Educação e filosofia» (Ensaios I), «Divagações pedagógicas» (Ensaios II), «O ensino como factor do ressurgimento nacional» (Conferência sobre a Reforma da Educação Nacional, 1918), "O self-government e a escola» (Educação cívica, 1915), "A função social dos estudantes», "Crise da democracia» (Democracia), "Confissões de um cooperativista», "O miguelismo e a Seara Nova» (artigo de 23.1.1926 no Novidades), «Duas palavras de advertência» - «Tentativas de remodelação metropolitana» (Breve interpretação da História de Portugal); 
«O testamento intelectual de António Sérgio» (O Seiscentismo;; «Album de fotografias colegiais» (3 fotos); "Medalha dedicada a António Sérgio»; «Novas homenagens a António Sérgio»; «Prémio camaradagem».

$J L$, Jornal de letras, artes e ideias, n. ${ }^{\circ}$ 57, 26 de Abril, 1983. «Dossier Sérgio (1883-1983). Pensar, pensar Portugal». (Contém: A. Campos Matos - «Diálogo c/ António Sérgio»; Matilde Pessoa de Figueiredo - «Cartas inéditas da juventude»; Jacinto Baptista - "Carcas inéditas de Bernardino Machado e António Sérgio, emigrados políticos, dois democratas de escol»; Henrique de Barros - "Sérgio e a Era da Abundância»; Fernando Ferreira da Costa - «Do socialismo libertário à sociedade alternativa»; A. L. Sousa Franco - «Sérgio e a economia»; Isabel Marnoto - «Retrato a preto e branco»; Natália Correia - «Modernidade da doutrina social - mas rispidez filosófica»; António Braz Teixeira - «Um filósofo mais conhecido pelos aspectos menores da sua obra»; Castelo Branco Chaves - «Análise rigorosa e solidez de pensamento»; Agostinho da Silva «Ombrear c/ Herculano»; Fernando Piteira Santos - «Uma personalidade ímpar»).

\section{Ile REPRESENTAÇÃO EM DICIONÁRIOS E ENCICLOPEDIAS}

Dicionário de Literatura, $2 .^{\circ}$ vol.

Porto, Livr. Figueirinhas, 1969, 1015-1016 pp.

Enciclopédia Luso-Brasileira de Cultura, vol. 16

Lisboa, ed. Verbo, 1974, 1807-1808 pp.

Focus, Enciclopédia Internacional, vol. 4

Lisboa, Livr. Sá da Costa, 1968

Grande Enciclopédia Portuguesa e Brasileira, vol. XXVIII

Lisboa, ed. Enciclopédia L.da, s/d. 409-411 pp.

Dicionário de História de Portugal (dirigido por Joel Serrão) vol. IV Lisboa, Iniciativas Editoriais, 525-526 pp. 


\section{Hf POLÉMICAS}

\section{fl ARTIGOS NÃO ASSINADOS}

«Alguns documentos sobre a polémica entre António Sérgio - Bento de Jesus Caraça». Vértice, n. ${ }^{\circ}$ 394-95, Mar.-Abr., Coimbra, 1977, 207-218 pp. (Correspondência trocada com a Vértice de A. S. e Bento de Jesus Caraça)

«Polémica Bento de Jesus Caraça - António Sérgio». Vértice, n. ${ }^{\circ}$ 301-2-3, Out.-Dez., 1968, 798-880 pp. (Contém: «nota a um passo de uma introdução a Berkeley» de A. S.; «Resposta a uma crítica» de Bento de Jesus Caraça; «Réplica sem severidade a um severo amigo» de A. S.; «Carta a António Sérgio - Crítico» de Bento de Jesus Caraça; «Explicações para os que entendem a linguagem que eu falo» de A. S.)

\section{f2 ARTIGOS ASSINADOS}

Chaves, Castelo Branco - «A primeira polémica de António Sérgio». Crítica inactual, Lisboa, ed. Arcádia, 1981, 163-171 pp. (publicado pela.$^{a}$ vez em $A$ Capital de 9 de Abril, 1969)

Gama, José - «A polémica saudosista: Teixeira de Pascoais e António Sérgio». Brotéria, n. ${ }^{\circ} 2$, Fev., 1982, 185-193 pp.

Garcia, Mário - «A Campanha saudosista de Teixeira de Pascoais e a sua polémica com António Sérgio». Revista Portuguesa de Filosofia, Braga, Jan.-Mar., 1976, 1-32 pp.

Pinto, Jaime Nogueira - «Polémicas de António Sérgio» in: As grandes polémicas portuguesas, ed. Verbo, fase. 29

\section{Ilg ARTIGOS SOBRE A CASA DE ANTÓNIO SÉRGIO E SUA BIBLIOTECA}

\section{gI NÃO ASSINADOS}

«Respeitado projecto de Raul Lino. Recuperação da casa de António Sérgio assinala centenário do seu nascimento». A Capital, 13 de Jul., 1983

«Casa onde viveu António Sérgio destruída por um incêndio». O Diário, 5 de Jan., 1980

«Casa de António Sérgio vai ser recuperada». O Dia, 13 de Jul., 1983

«A casa de António Sérgio vai ser expropriada». O Diário, 14 de Abr., 1980

«Casa de António Sérgio reconstruída de raiz». O Diário, 15 de Jul., 1983 
«Em ruínas a casa de António Sérgio». Diário de Lisboa, 28 de Set., 1977

«Carta no post scriptum acerca do suplemento saído a 29.9.977, pelo proprietário da casa onde viveu António Sérgio e resposta da nota da Redacção reafirmando os mesmos propósitos expressos por Sttaut Monteiro». Diário de Lisboa, 10 de Out., 1977

«Em ruínas e ao abandono a casa de António Sérgio». Diário de Lisboa, 29 de Set., 1977

«Finalmente a casa de Sérgio vai entrar no património nacional». Diário de Lisboa, 12 de Abr., 1978

«Um escândalo nacional. Incêndio destrói parte da casa de António Sérgio». Diário de Lisboa, 5 de Jan., 1980

«Biblioteca de António Sérgio finalmente em segurança». Diário de Lisboa, 5 de Fev., 1980

«Terceiro incêndio na casa de António Sérgio». Diário de Lisboa, 12 de Fev., 1980

«Casa de António Sérgio expropriada e declarada de utilidade pública». Diário de Lisboa, 14 de Abr., 1980

«O espírito de educador» (texto de $A . S$. de «O cooperativismo e o Estado», c/ excelente foto de grupo tirada no interior da casa c/ os intelectuais que constituíam a sua tertúlia). Diário de Lisboa, 10 de JuL, 1981

«Instituto António Sérgio na posse da casa do ensaísta». Diário de Lisboa, 26 de Jan., 1982

«Casa de Sérgio protocolo assinado». Diário de Lisboa, 2 de Mar., 1982

«Casa António Sérgio: obras de recuperação custam 40 mil contos». Diário de Lisboa, 3 de Mar., 1982

«António Sérgio homenagem no Parlamento». Diário de Lisboa, 7 de Maio, 1982

«Destruída por violento incêndio a casa que foi de António Sérgio». Diário de Notícias, 5 de Jan., 1980

«Casa de António Sérgio é de utilidade pública». Diário de Notícias, 12 de Abr, 1980

«Abertura pública das propostas para a empreitada. Nova casa de António Sérgio ficará concluída em 600 dias». Diário de Notícias, 13 de Jul., 1983

«Um crime que é preciso evitar: destruir-se a casa de António Sérgio». Diário Popular, 19 de Fev, 1975

«Um crime que é preciso evitar: a destruição da casa de António Sérgio. Intervenção do Estado ou da Gulbenkian - sugestão expressa num documento assinado por 100 cooperativistas». Diário Popular, 1 de Mar, 1975

«Um crime que é preciso evitar: a destruição da casa de António Sérgio. Na hora presente o nome e a obra de Sérgio carecem de ser relembrados». Diário Popular, 24 de Abr, 1975

«A casa de Sérgio um escândalo»! Diário Popular, 17 de Nov, 1977

«Salve-se a casa de António Sérgio» (dois depoimentos). Diário Popular, 2 de Dez, 1977

«Autor dos Ensaios nasceu há cem anos. Restaurar a casa de António Sérgio é homenagear o movimento cooperativo». Jornal de Notícias, 10 de Fev, 1983

«Casa de António Sérgio será centro de estudos». Jornal de Notícias, 3 de Mar, 1982

«Recupera-se a casa de António Sérgio». O Ponto, 14 de Jan, 1982

«Casa de António Sérgio arde pela terceira vez». Portugal Hoje, 15 de Jan, 1980 
Agudo, Prof. Dias - «Um crime que é preciso evitar: a destruição da casa de Antonio Sérgio. Que ali se crie um centro de estudos do cooperativismo sugere o prof. Dias Agudo». Diário Popular, 17 de Maio, 1975. (C/ depoimentos de Fernando de Almeida e dr. João Luis Barroco da Fonseca. Apresenta documentário fotográfico de interiores. Fim da campanha em prol da salvação da casa)

Branco, João de Freitas - «Ao que não deve servir a casa de António Sérgio». Diário de Lisboa, 23 de Mar., 1978

Branco, Fernando Castelo - «A casa de António Sérgio». A Capital, 28 de Fev., 1975

Cautela, Afonso - "António Sérgio: a vacina antitotalitária». Portugal Hoje, 28 de Jan., 1982

Chaves, Castelo Branco - «Um crime que é preciso evitar: a destruição da casa de António Sérgio. Num país ilustrado a Campanha do Diário Popular desencadearia uma grande manifestação cívica, lembra Castelo Branco Chaves». Diário Popular, 26 de Fev., 1975

Costa, Fernando Ferreira da - «Casa António Sérgio. Memória descritiva de utilização». Casa António Sérgio vol. I; Relatório da actividade desenvolvida pela INSCOOP para a recuperação da casa de António Sérgio, vol. II (vol. I: I -Memória descritiva de utilização II - A imprensa e a casa de António Sérgio (recortes) III - Fotografias; vol. II: Relatório, anexo I, anexo II, anexo III, c/ reprodução do projecto primitivo da casa, de Raul Lino). Lisboa, INSCOOP, Instituto António Sérgio do sector cooperativo. Departamento de Informação, Jan., 1982

Costa, João Sá da - «Um crime que é preciso evitar: a destruição da casa de António Sérgio. Um ponto de encontro ${ }^{\wedge}$ e de reflexão. Objectivo defendido por João Sá da Costa». Diário Popular, 6 de Mar, 1975

Dionísio, Sant’Anna - «Um crime que é preciso evitar: a destruição da casa de António Sérgio. A destruição não me causa espanto- está na linha de tantas outras expressões de incúria, grosseria, barbarismo e ingratidão - palavras de Sant'Anna Dionísio». Diário Popular, 1 de Abr, 1975

Fernandes, Barahona - «As Pedras Vivas da casa de António Sérgio. Diário de Lisboa, 23 de Nov, 1977

Ferreira, Jaime - «Um crime que é preciso evitar: a destruição da casa de António Sérgio. Para o homem de acção prodígio de humanismo - depõe Jaime Ferreira. Diário Popular, 11 de Mar, 1975

Ferreira, José Gomes - «Um crime que é preciso evitar, a demolição da casa de António Sérgio. Não acredito! Exclama José Gomes Ferreira. Diário Popular, 22 de Fev, 1975

França, José Augusto - «Um crime que é preciso evitar: negativo! Absurdo e criminoso! Depõe José Augusto França. Diário Popular, 20 de Fev, 1975

Godinho, Vitorino Magalhães - «Um crime que é preciso evitar: a destruição da casa de António Sérgio. ...E se fossemos sergianos? Porque ventriloquos de outros pensamentos desconhecemos o contexto internacional e somos apenas parolos, palavras do prof. Vitorino Magalhães Godinho». Diário Popular, 8 de Mar, 1975 
Leitão, Ruben Andresen- «Um crime que é preciso evitar: Salve-se a casa de um dos nossos maiores pensadores! Depoimento de Ruben Andresen Leitão». Diário Popular, 21 de Fev., 1975

Matos, A. Campos - «A casa de António Sérgio ainda...» O Ponto, n. ${ }^{\circ}$ 68, 18-24 de Fev., 1982. ( $\mathrm{C} /$ comentários sobre problemas arquitectónicos e éticos decorrentes do projecto de recuperação da casa)

Monteiro, Luis de Sttau - «A casa de António Sérgio». Diário de Lisboa, 29 de Set., 1977 (com 11 fotos de Rui Pacheco)

Moura, Helena Cidade - «António Sérgio - a sua casa». Diário de Lisboa, 23 de Jan., 1978

Pacheco, Luiz - «A casa derruída». Diário Popular, 18 de Dez., 1983

Rau, Fernando - «Em casa de António Sérgio». A Capital, 7 de Maio, 1969. (C/ 4 aspectos fotográficos de interiores)

Salema, Álvaro - «Um crime que é preciso evitar: a destruição da casa de António Sérgio. A dívida a pagar é de toda a nação, afirma Alvaro Salema». Diário Popular, 4 de Mar., 1975

Santos, Fernando Piteira - «Um crime que é preciso evitar: antes uma ruína a envergonhar-nos do que consentirmos em sermos todos ofendidos - a opinião de Fernando Piteira Santos». Diário Popular, 25 de Fev., 1975

Santos, Fernando Piteira - «A casa de António Sérgio; a obra de António Sérgio; Sérgio e a política do possível» (secção política de A a Z). Diário de Lisboa, 13 de Abr., 1978

Serrão, Joel - «Um crime que é preciso evitar: a demolição da casa de António Sérgio. Para o centro de estudos uma coisa parece evidente: o local certo seria na casa da Travessa dó Moinho de Vento». Diário Popular, 24 de Fev., 1975

Silva, Agostinho da - «Um crime que é preciso evitar: $\mathbf{a}^{\wedge}$ destruição da casa de António Sérgio. Os sábados em casa de Sérgio foram um pensar crítico e a descoberta do valor do povo - escreve Agostinho da Silva». Diário Popular, 10 de Mar., 1975

Scusa, Eng.ro Carlos Marques de - «Post-Scriptum. Depoimento do Eng.ro Carlos Marques de Sousa». Diário de Lisboa, 10 de Out., 1977

Tavares, Salette - «Um crime que é preciso evitar: a destruição da casa de António Sérgio. Há que acabar com as casas-museus mortas, afirma Salette Tavares». Diário Popular, 7 de Mar., 1975

Tengarrinha, José - «Um crime que é preciso evitar: a destruição da casa de António Sérgio. Destrui-la é apagar algo de importante da vida de um dos maiores vultos da História do Pensamento Português, declara José Tengarrinha». Diário Popular, 5 de Mar., 1975

\section{Ilh NECROLOGIA}

«Faleceu António Sérgio antigo Ministro da Instrução Pública. O ensaísta e escritor foi um dos mais devotados defensores do Cooperativismo». O Comércio do Porto, 25 de Jan., 1969

«O funeral de António Sérgio constituiu imponente manifestação de pesar». O Comércio do Porto, 27 de Jan., 1969 
«O funeral de Antonio Sérgio reuniu centenas de pessoas de todas as classes sociais». A Capital, 26 de Jan., 1969

«A morte de António Sérgio - grande pensador doutrinário e democrata». Diário de Lisboa, 25 de Jan., 1969

«Milhares de pessoas no funeral de António Sérgio». Diário de Lisboa, 26 de Jan., 1969

«O dr. António Sérgio ensaista e escritor faleceu ontem». Diário de Notícias, 25 de Jan., 1969

«O funeral de António Sérgio realizou-se ontem para o cemitério dos Prazeres». Diário de Notícias, 27 de Jan., 1969

«A morte de António Sérgio - eminente cidadão pedagogo e ensaísta». Diário Popular, 25 de Jan., 1969

«Sentida homenagem a António Sérgio». Diário Popular, 26 de Jan., 1969. (Sobre esta notícia e os cortes nela exercidos pela censura salazarista ver: «Perseguição do fascismo mesmo além da morte», Correio do Minho de 26 de Fev., 1983, por Jacinto Baptista)

«Faleceu António Sérgio antigo Ministro da Instrução Pública». O Primeiro de Janeiro, 25 de Jan., 1969

«Milhares de pessoas acompanharam o funeral do grande pensador António Sérgio». República, 26 de Jan., 1969

«O funeral de António Sérgio constituiu uma grandiosa e comovente manifestação de pesar pela perda do eminente homem público e uma das mais altas figuras das letras pátrias». República, 27 de Jan., 1969

«Morreu António Sérgio alto expoente da vida pública e da cultura». O Século, 25 de Jan., 1969

«Milhares de pessoas acompanharam o funeral de António Sérgio». O Século, 27 de Jan., 1969

Discursos proferidos junto ao ataúde, no cemitério dos Prazeres, às 12,30 do dia 26 de Jan., 1969, por: Prof. Luis Ernani Dias Amado (Presidente da A G da Liga Portuguesa dos Direitos do Homem) e dr. Fernando Mayer Garção, in: Diário de Lisboa, n. ${ }^{\circ} 70,29$ de Jul., 1982

\section{Ui BIBLIOGRAFIAS}

Águas, Neves - Bibliografia publicada na Vida Mundial, n..$^{\circ} 1548$ de 7 de Fev., 1969, $42-45$ pp. (O n. ${ }^{\circ} 1553$ de 14 de Mar., 1969, apresenta algumas rectificações a esta bibliografia: "Candido de Sousa - achegas à bibliografia de António Sérgio», 64 p.)

Matos, A. Campos - «Bibliografia de António Sérgio». Vértice, n. ${ }^{\circ}$ 319-20, Ag.-Set., 1970, 568-597 pp.

Matos, A. Campos - «Bibliografia de António Sérgio», Coimbra, separata da Vértice, 1971, 47 p. (revisão da versão publicada na revista, c/ correç̧ões, acrescentos e diferente critério de arrumação, acrescida de uma «Nota Prévia»)

Sérgio, António - Bibliografia sumária organizada pelo escritor e aposta ao Pátio das Comédias das Palestras e das Prègações, Lisboa, Ed. Inquérito, 1958 


\section{Ilj ELEMENTOS BIOGRÁFICOS:}

a - No Arquivo da Marinha:

Registo biográfico - Livro Mestre, livro G, 72 p.

Album fotográfico n. 6 (foto n. ${ }^{\circ}$ 934) (A. S. fardado com divisas de $2 .^{\circ}$ Tenente)

índice alfabético de oficiais (até 31-12-1910) caixa n. ${ }^{\circ} 652$ (onde se encontra o processo de A. S.)

b - Grande Enciclopédia Portuguesa e Brasileira, 409-411 pp.

c - Nobreza de Portugal, vol. III, Lisboa, ed. Enciclopédia, 1961, 371 a $374 \mathrm{pp}$. (c/ desenvolvidas noticias, também, sobre os ascendentes)

d - Ficha do arquivo biográfico do Diário de Notícias, preenchida por A. S.

e - Apontamentos biográficos redigidos por A. S. para as Notas de Esclarecimento. Separata da Portucale, Porto, 1950

\section{RESENHA DAS PUBLICAÇÕES PERIODICAS CITADAS}

Acção

Agros

A Águia

Almanaque dos Palcos e Salas

Anais da Academia dos Estudos Livres

Anais do Club Militar Naval

Análise Social

Anhembi (S. Paulo, Brasil)

Aqui e Além

Arquivo Coimbrão

Atlântida

A Batalha

Boletim Cooperativista

Boletim Informativo para as Cooperativos do concelho central

das Cooperativas de Lisboa e arredores (policopiado)

Boletim Pedagógico

Boletim da Sociedade Luso-Africana do Rio de Janeiro

Brotéria

Bulletin des Études Portugais

Cadernos de Poesia

Camiliana \& Vária

A Capital

A Cidade, revista cultural de Portalegre

Claridade

Clio. Revista do Centro de História da Univ. de Lisboa

Colecção Oficial de Legislação Portuguesa

Colóquio Letras

Correio do Minho

Critério, revista mensal de cultura

Cronos 
Descobrimento

O Diabo

O Diário

Diário Liberal

Diário de Lisboa

Diário da Noite

Diário de Notícias

Diário Popular

Educação Social

Espaço T Magazine

O Estado de S. Paulo (Brasil)

Expoente (S. Paulo, Brasil)

Filosofia e Epistemologia

Gazeta Musical

Gil Vicente, revista de cultura e actualidade

Gleba, semanário de literatura e crítica

Guia de Leitores

História, publicação mensal

Homens Livres

Idem, Jornal de alunos da Faculdade de letras de Lisboa

O Jornal

JL, Jornal de letras, artes e ideias

Jornal de Letras e Artes

Jornal de Notícias

Ler

Lusíada

Lusitânia

A Luta

A Monarquia, diário integralista da tarde

O Mundo Literário

Nação Portuguesa

Notícia de Huila

Ocidente

Pela Grei

Pim! Pam! Pum!

O Ponto

Portucale

Portugal Hoje

Presença

O Primeiro de Janeiro

República

Revista Americana (Rio de Janeiro, Brasil)

Revista da Associação dos Antigos Alunos do Colégio Militar

Revista Cultura-História e Filosofia

Revista de Educação Geral e Técnica

Revista de Guimarães

Revista do Porto

Revista de Portugal

Revista Portuguesa

Revista Portuguesa de Filosofia

Revista Portuguesa de Psicologia

Revue Bleu (Paris)

Revue de Genève

Revue Mondiale (Paris)

Seara Nova

O Século

Serões 
Bibliografia de António Sérgio

\author{
Síntese \\ Sol Nascente \\ O Tempo e o Modo \\ Tempo Livre (F.A.O.J.) \\ Terra Mãe, semanário regionalista (Pombal) \\ Terra de Sol (Rio de Janeiro) \\ O Trabalho, semanário republicano \\ Unicórnio \\ Ver e Crer \\ Vértice \\ A Vida Portuguesa \\ Vida Mundial \\ A Voz \\ A Voz da Justiça
}

